\title{
Geology and Phosphate Deposits of the Permian Rocks in Central Western Montana
}

GEOLOGICAL SURVEY PROFESSIONAL PAPER 313-F

This report concerns work done as part of the program of the Department of the Interior for development of the Missouri River basin, and work done partly on behalf of the U.S. Atomic Energy Commission

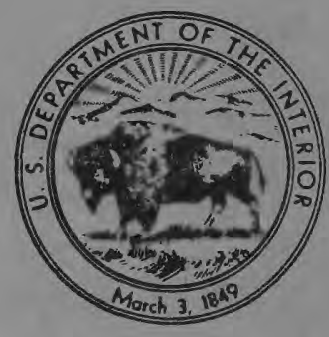


Xas $-x=3$

alition

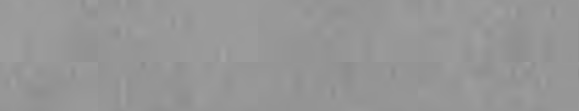

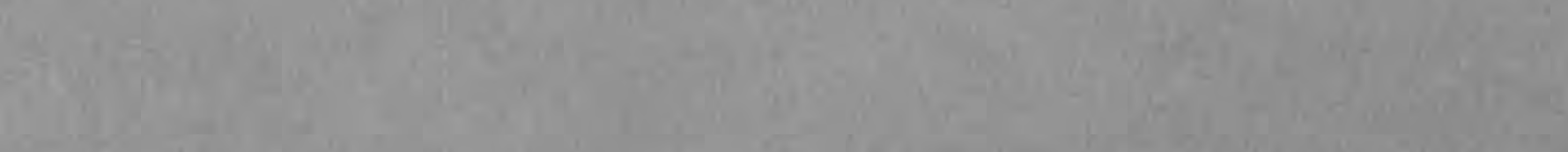

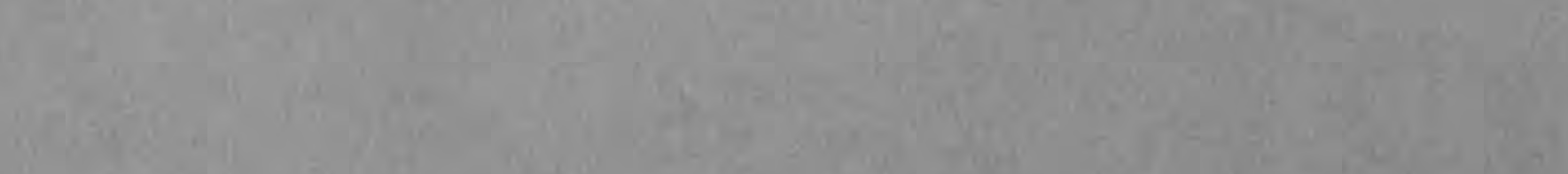

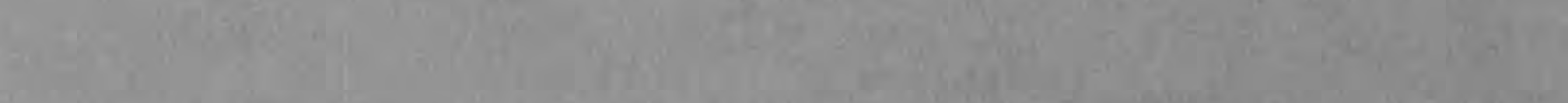

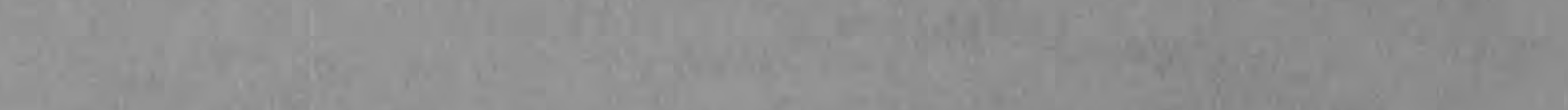

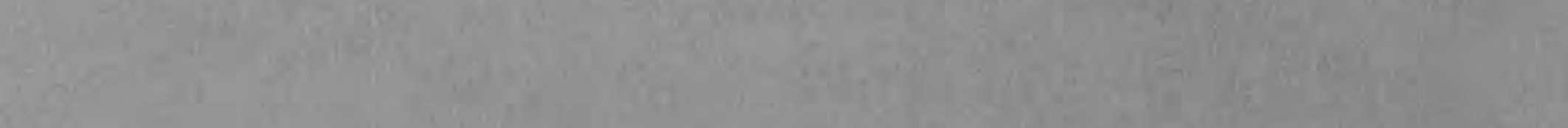

What

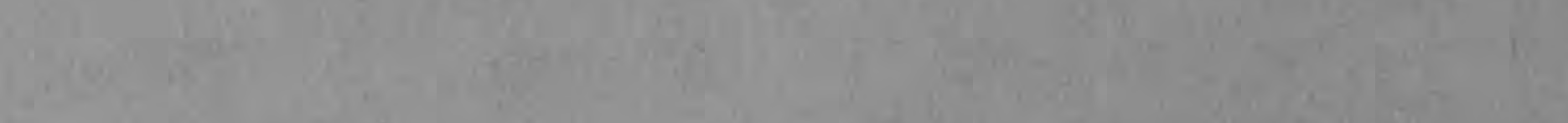

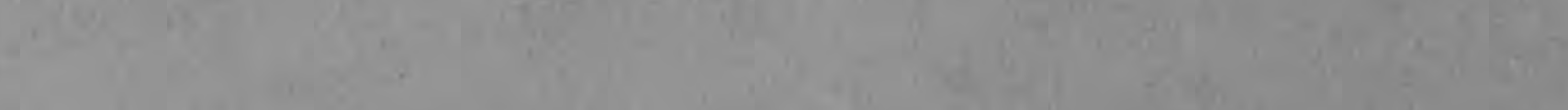

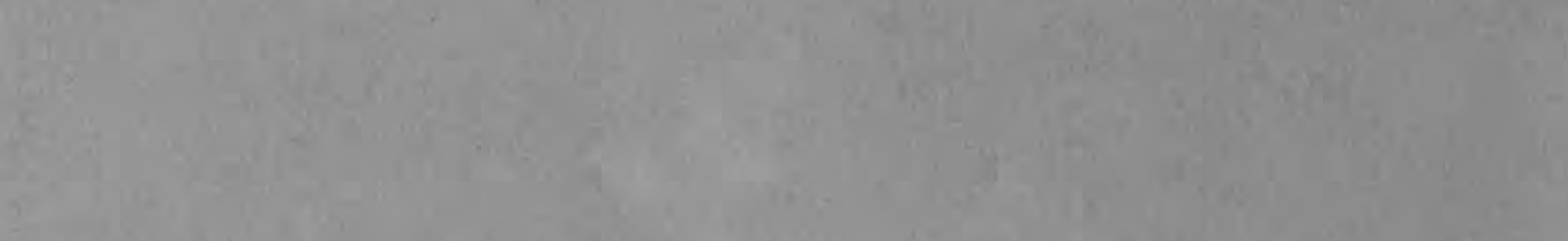
$\ln ^{6}=x^{2} x$
ingta

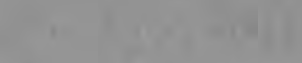

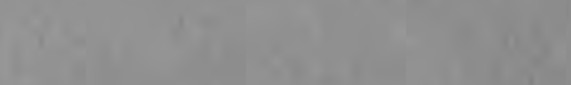

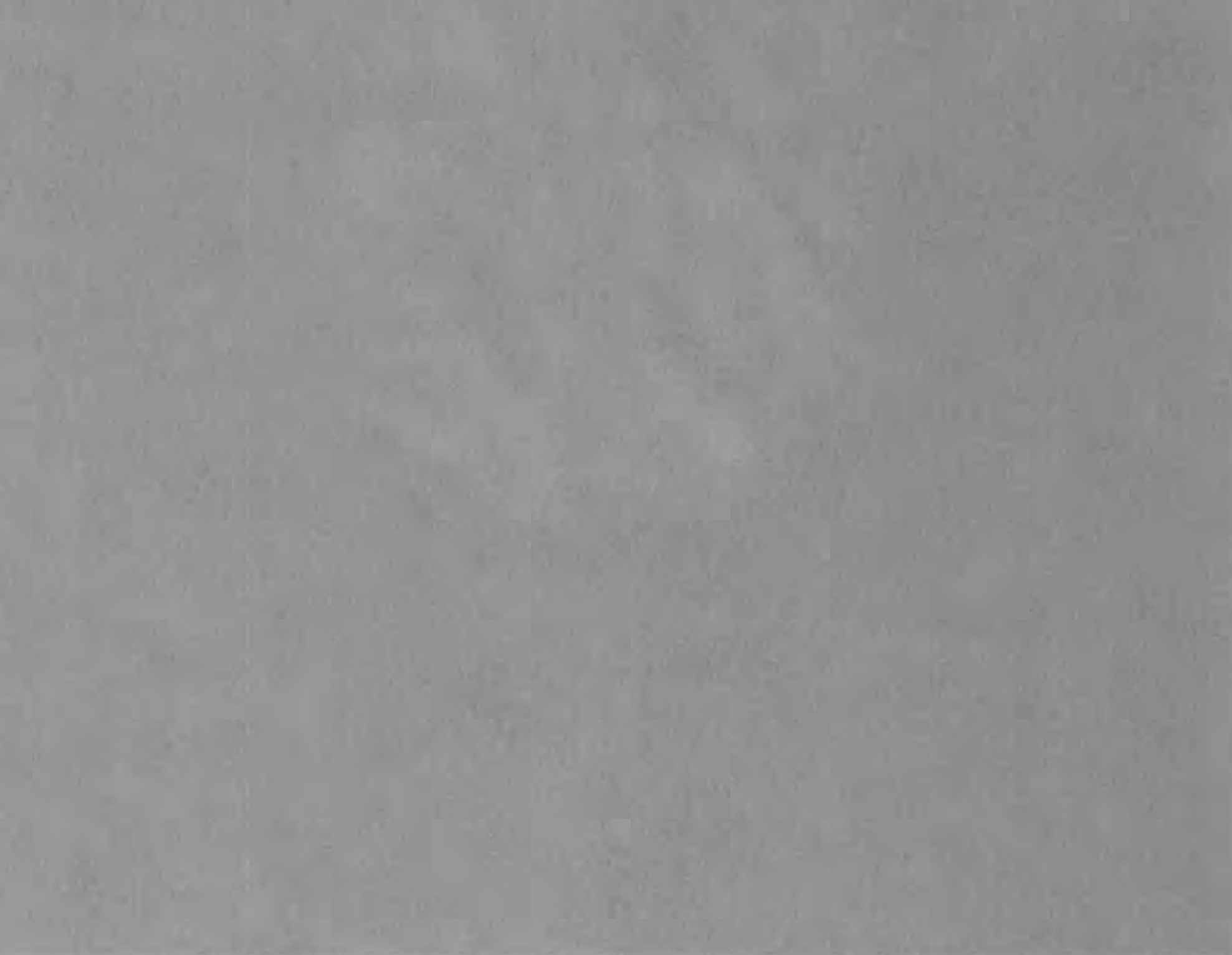

(3) 


\section{Geology and Phosphate Deposits of the Permian Rocks in Central Western Montana}

By ROGER W. SWANSON

GEOLOGY OF PERMIAN ROGKS IN THE WESTERN PHOSPHATE FIELD

GEOLOGIGAL SURVEY PROFESIONAL PAPER 313-F

This report concerns work done as part of the program of the Department of the Interior for development of the Missouri River basin, and work done partly on behalf of the U.S. Atomic Energy Commission

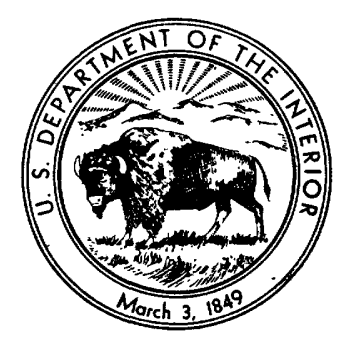

Descriptions of Permian rocks and of structure of enclosing rocks at north end of western phosphate field, with measured sections, chemical analyses, and phosphate resource tables 


\section{UNITED STATES DEPARTMENT OF THE INTERIOR}

ROGERS C. B. MORTON, Secretary

\section{GEOLOGICAL SURVEY}

V. E. McKelvey, Director

Library of Congress catalog-card No. 72-600316

Stock Number 2401-2201 


\section{CONTENTS}

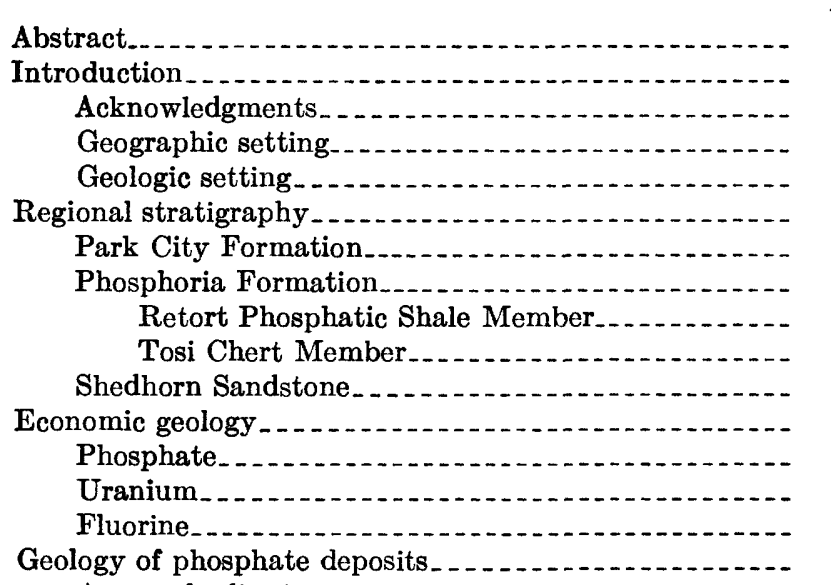

Anaconda district.

\begin{tabular}{r|} 
Page \\
779 \\
779 \\
781 \\
781 \\
782 \\
785 \\
785 \\
786 \\
786 \\
786 \\
787 \\
788 \\
788 \\
789 \\
792 \\
792 \\
792
\end{tabular}

Geology of phosphate deposits-Continued

Pbilipsburg district.......... 795

Maxville district...

Gird Creek syncline........................ 806

Douglas Creek syncline.................. 807

Coberly syncline....................... 807

Gold Creek syncline.

Pendant syncline ... . . . .

Garrison district................. 810

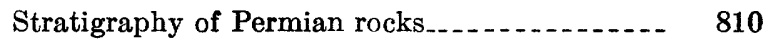

Structure of Permian rocks . . . . . . . . . . . . . . 818

Phosphate deposits....... 819

Elliston district............. 821

Helena-Three Forks area_...

Summary of phosphate resources in central western

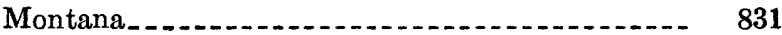

References cited. 832

\section{ILLUSTRATIONS}

[Plates 30-34 are in pocket]

Plate 30. Map of central western Montana phosphate field showing sample localities and areas underlain by Permian rocks.

31. Columnar sections showing correlation of rocks of Permian age in central western Montana.

32. Columnar sections showing correlation of Retort Phosphatic Shale Member of Phosphoria Formation in central western Montana.

33. Graphs showing stratigraphic distribution of phosphate within the Retort Phosphatic Shale Member of Phosphoria Formation in central western Montana.

34. Structure contour maps drawn on base of Permian rocks in phosphate districts in central western Montana.

FigdRE 199. Index maps showing area of this report and areas covered by previously published reports

200. Map showing percentage of apatite plus acid-insoluble content of Retort Phosphatic Shale Member of Phosphoria Formation.

201. Graph comparing chemical and equivalent uranium in samples.

202-204. Graphs comparing $\mathrm{P}_{2} \mathrm{O}_{3}$ and equivalent uranium in-

202. Samples

203. Phosphate zones

204. Lots 1340 and 1386

205-207. Index maps showing resource blocks in-

205. Anaconda, Philipsburg, and Maxville districts

206. Garrison district.

207. Elliston district._. 


\section{TABLES}

TABLES 1-3. Measured section and analyses of-

Page

1. Permian rocks near Anaconda quarry, Montana, lot 1337

2. Permian rocks in Dissett mine, Montana, lot 1386

3. Retort Phosphatic Shale Member of Phosphoria Formation in Moonlight mine, Montana, lot 1340_..

4. Measured section of Permian rocks near Little Gold Creek, south of Moonlight mine, Montana 5-8. Measured section and analyses of-

5. Permian rocks on west limb of Douglas Mountain anticline near Gird Creek, Montana, lot 1387 ...-

6. Retort Phosphatic Shale Member of Phosphoria Formation in Douglas Creek No. 3 North mine, Montana, lot 1388

7. Retort Phosphatic Shale Member of Phosphoria Formation in east adit of Edgar mine, Montana, lot 1389

8. Permian rocks on east limb of Douglas Mountain anticline near Gird Creek, Montana, lot 1399.... 9. Average chemical composition of zones in Retort Phosphatic Shale Member of Phosphoria Formation in Anaconda, Maxville, and Philipsburg districts, Montana

10. Phosphate resources in the Retort Phosphatic Shale Member of the Phosphoria Formation, Anaconda, Philipsburg, and Maxville districts, Montana 11-14. Measured sections and analyses of -

11. Retort Phosphatic Shale Member of Phosphoria Formation in Luke mine, Montana, lot 1285_.... 12. Permian rocks in Graveley mine, Montana, lot $\mathbf{1 2 8 6}$

13. Permian rocks in Anderson mine, Montana, lot 1287 $\ldots$

14. Permian rocks near Warm Springs Creek, Montana, lot 1402

15. Phosphate resources in the Retort Phosphatic Shale Member of the Phosphoria Formation, Garrison district Montana

16-19. Measured section and analyses of -

16. Permian rocks in pipeline trench near Elliston, Mont., lot 1397

18. Permian rocks in Jack Pine mine, Montana lot 1400

19. Retort Phosphatic Shale Member of Phosphoria Formation in Senecal incline, Montana, lot 1401.--

20. Phosphate resources in the Retort Phosphatic Shale Member of the Phosphoria Formation, Elliston district,

Montana.........

21. Measured section and analyses of Permian rocks northwest of Wheatland School, Montana, lot 1384_--.-

22. Summary of phosphate resources in the Retort Phosphatic Shale Member of the Phosphoria Formation in central western Montana. 


\title{
GEOLOGY OF PERMIAN ROGKS IN THE WESTERN PHOSPHATE FIELD
}

\section{GEOLOGY AND PHOSPHATE DEPOSITS OF THE PERMIAN ROCKS IN GENTRAL WESTERN MONTANA}

\author{
By Roger W. Swanson
}

\begin{abstract}
The central western Montana phosphate area at the north end of the western phosphate field includes about 5,000 square miles north of lat $46^{\circ}$ and between long $111^{\circ} 30^{\prime}$ and $113^{\circ} 20^{\prime} \mathrm{W}$. It is within the northern Rocky Mountains, astride the Continental Divide. The west part is drained mostly by the Clark Fork, the east part by the Missouri. The area is characterized by mountain ranges, some more than 9,000 feet above sea level, that are separated by intermontane basins 4,000 to 5,000 feet above sea level.
\end{abstract}

The area was complexly folded and faulted during the Laramide orogeny, and it was intruded by many plutonic rock bodies, of which the Boulder batholith is the largest. Volcanic rocks are extensive and bury some of the phosphate deposits.

Much of the area is underlain by phosphate-bearing Permian rocks whose outcrops, mostly at altitudes of less than $\mathbf{7 , 0 0 0}$ feet, have a total length along the strike of more than 275 miles. The area includes the most productive part of the Montana phosphate field and contains its richest deposits. In the course of the work on which this paper is based, Permian strata were measured, sampled, and described at 16 localities.

Permian strata that crop out in this area belong to the Phosphoria, Shedhorn, and Park City Formations, whose maximum aggregate thickness is a little more than 100 feet. Nearly all the phosphate in this part of Montana is in the Retort Phosphatic Shale Member of the Phosphoria Formation. Most of the phosphate is in pellet form, although in the eastern part of the area some of it is oolitic, nodular, or structureless. The detailed stratigraphy of the Retort Member is discussed, as are the structures that affect its present distribution.

In areas where phosphate resources can be estimated, the Retort Member contains more than 600 million tons of highgrade phosphate rock ( 31 percent $P_{2} O_{5}$ ) in beds that are at least 3 feet thick; more than half this amount is in the Garnet Range. The Retort Member also contains nearly 2 billion tons of rock that contain more than 24 percent $\mathrm{P}_{2} \mathrm{O}_{5}$, two-thirds of it in the Flint Creek Range district, and about $2 \frac{1}{2}$ billion tons that contain more than 18 percent $\mathrm{P}_{2} \mathrm{O}_{5}$. Only about 10 percent of the phosphate rock, however, is above entry level.

Fresh phosphorite in this part of Montana contains about 1 part uranium for each 3,000 parts of $\mathrm{P}_{2} \mathrm{O}_{5}$. The total amount of uranium in phosphatic rock of all grades in the areas for which phosphate resources are estimated may be nearly 280,000 tons; that in rock containing 31,24 , and 18 percent $\mathrm{P}_{2} \mathrm{O}_{5}$ is $64,000,181,000$, and 224,000 tons, respectively.

Fluorine in the carbonate fluorapatite occurs in the ratio of 1 part for every 10 parts of $\mathrm{P}_{2} \mathrm{O}_{5}$. Total fluorine in all phosphatic rocks in the areas for which phosphate resources are estimated is 83 million tons; that in rock containing 31,24 , and 18 percent $\mathrm{P}_{2} \mathrm{O}_{5}$ is 19,54 , and 71 million tons, respectively.

\section{INTRODUCTION}

The first discoveries of rock phosphate in the western phosphate field were made at about the turn of the century in southeastern Idaho and adjoining areas. The first discovery in Montana was made by Gale (1911) near Melrose in the summer of 1910. In 1911, Pardee (1913) discovered phosphate rock at Philipsburg in the Flint Creek Range, in the Garnet Range north of Garrison, and at Elliston, and R. W. Stone found it in Jefferson Canyon east of Cardwell. After World War II, extensive investigations were carried out in the entire western phosphate field. Preliminary reports of this work were made by McKelvey (1949) and Swanson, McKelvey, and Sheldon (1953). Cressman and Swanson (1964) reported on the stratigraphy and petrology of the Permian rocks in the area south of Butte, and Swanson (1970) reported on the mineral resources in those rocks. These two papers include descriptions of the methods of study, define the terminology used during this program, and go into detail regarding the stratigraphy, mining methods, mill treatment of phosphate rock, and means of estimating resources. The stratigraphic names used in this report are defined in a report by McKelvey and others (1959). The color designations in the measured sections are those of the Munsell color system as noted on the "Rock-Color Chart" distributed by the National Research Council (Goddard, 1948) and on a chart specially prepared for the phosphate studies that provided more detail in the range of colors most common to Phosphoria rocks.

This report describes the geology and mineral resources of the Permian rocks at the north end of the western phosphate field, an area north of Butte consisting of nearly 5,000 square miles between lat $46^{\circ}$ and $46^{\circ} 50^{\prime}$ N. and long $111^{\circ} 30^{\prime}$ and $113^{\circ} 20^{\prime}$ W. (fig. 199). 

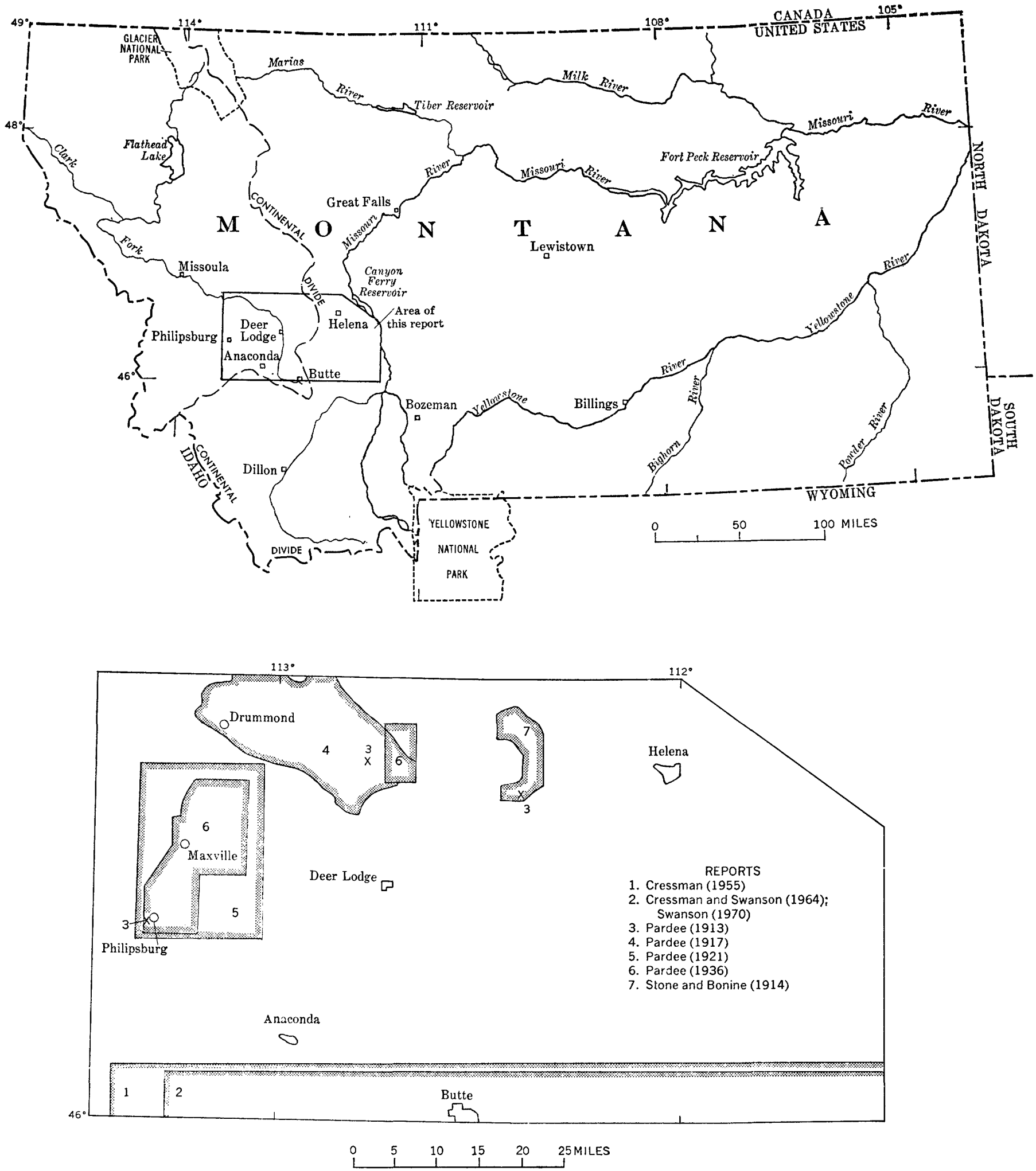

FIGURE 199. -Index maps showing area of this report (above) and areas covered by previous reports on phosphate within the area of this report (below). 
The investigation was conducted as part of the program of the Department of the Interior for development of the Missouri River basin and was supported in part by the Division of Raw Materials of the U.S. Atomic Energy Commission.

This report includes descriptions of Permian strata measured and sampled at 16 localities, referred to by name or lot number. Most of the analytical data, together with brief descriptions of the stratigraphic sections, have been published by Klepper, Honkala, Payne, and Ruppel (1953), Swanson, Cressman, Jones, and Replogle (1953), and Swanson, Carswell, Sheldon, and Cheney (1956). The analytical data and fuller stratigraphic descriptions are included in this report, in which liberal use has also been made of information in reports by Pardee $(1913,1917,1921,1936)$ and by Stone and Bonine (1914).

More than half the localities where samples were taken and sections measured were underground in mines or prospects. This generally insured that the rock sampled was fresh, but it also limited the thickness of the sections accessible for measurement. Most of the remaining sections were measured in trenches dug with bulldozer or by hand. Descriptions of the other Permian rocks in this area, therefore, are based on less complete information. The methods employed in describing and sampling the rocks, and in the treatment of samples, were the same as those that have been applied in other parts of the western phosphate field. (See Cressman and Swanson, 1964.) In the laboratory all hand specimens were examined under the binocular microscope, powders of many of the samples were examined in oils, and thin sections of about a dozen specimens were studied under the petrographic microscope.

In this report, as in the report on resources in Permian rocks in southwest Montana (Swanson, 1970), the term "phosphate" (a phosphorus compound) is used in a chemical sense for both the raw material and the products made from it (not including elemental phosphorus); the term "phosphate rock" is used in an industrial sense for the material mined and treated, or potential thereto; the term "phosphorite," a lithologic term, is used in a descriptive sense for a rock containing more phosphate mineral than any other rock component; and the term "phosphatic" is used for a rock in which the phosphate mineral represents more than 20 percent of the total (7.8 percent $\mathrm{P}_{2} \mathrm{O}_{5}$ ) but is not the dominant component. The phosphate rock may be almost entirely phosphorite, as in some of the high-grade deposits of this region, or it may be a mixture of rock types, dominantly phosphorite but including mudstone, sandstone, carbonate rock, or chert, generally interbedded with the phosphorite.

\section{ACKNOWLEDGMENTS}

Sampling in the mines of the Montana Phosphate Products Co. (lots 1285, 1286, and 1287) was done by M. R. Klepper. The section northwest of Wheatland School, on the east side of the Boulder batholith (lot 1384), was measured by E. T. Ruppel and D. E. Brambilla. All other sections described in this report were measured by the writer, assisted in part by R. A. Zeller (lots 1337 and 1340) and G. Abele (lot 1386). The writer devoted a small amount of field study to the Permian stratigraphy and general basic geology of the region, but nearly all the background geological information has been taken from published sources.

The guidance of V. E. McKelvey, under whose supervision the studies of the western phosphate field were organized and conducted, is gratefully acknowledged. The work of Cressman in southwestern Montana has also been of much help in this area.

\section{GEOGRAPHIC SETTING}

The phosphate field of central western Montana is within the Northern Rocky Mountains physiographic province and is characterized by a number of more or less distinct mountain ranges separated in part by broad lowlands or intermontane basins that occupy less than a fourth of the total area. These lowlands are as much as 10 miles wide and have intravalley relief ranging from a few hundred to more than 1,000 feet; the largest is Deer Lodge Valley. The field is traversed from north to south by the Continental Divide. West of the divide, the altitude of the Clark Fork River within the area decreases downstream from more than 5,000 to less than 4,000 feet; on the east, the altitude of the Missouri River where it leaves the area is a little less than 4,000 feet.

Northern and southern branches of the Northern Pacific Railroad pass through Helena and Butte, respectively, join at Garrison near the north end of Deer Lodge Valley, and follow the Clark Fork westward to Missoula. A spur of this line extends southward from Drummond to Philipsburg, on the west side of the Flint Creek Range; another runs up Brock Creek to phosphate mines in the Garnet Range. The Chicago Milwaukee Saint Paul and Pacific Railroad follows nearly the same route as the Northern Pacific from Butte to Missoula. The Butte Anaconda and Pacific connects Butte and Anaconda and extends about 5 miles farther west up Warm Springs Creek. The Great Northern Railroad connects Butte with Helena.

U.S. Highways $10 \mathrm{~N}$ and $10 \mathrm{~S}$ follow the railroad routes and join at Garrison en route to Missoula. U.S. Highway $10 \mathrm{~A}$, extending from the south end of Deer Lodge Valley to Drummond, passes around the south and west sides of the Flint Creek Range via Anaconda 
and Philipsburg. U.S. Highway 91 connects Butte with Helena. Most of the other roads in the area are unsurfaced, and many unimproved roads penetrate or cross the mountains.

The principal phosphate areas (pl. 30) are in or near the Flint Creek Range and the Garnet Range in the northwestern part of the area. Most of the Flint Creek Range is above 7,000 feet; many of its peaks rise above 9,000 feet and are glaciated. The greater part of the Garnet Range is below 6,500 feet, and its upland slopes are gently rounded. Both ranges are sharply incised by canyons. The Anaconda Range, in the southwest corner of the area, is higher than either of these and is more rugged and strongly glaciated; many of its peaks are above 10,000 feet. It is separated from the Flint Creek Range by Warm Springs Creek, which flows eastward through Anaconda into the southern part of Deer Lodge Valley. The only Permian rocks in the Anaconda Range are near its northern base. Between the Deer Lodge Valley and the Missouri River lowlands is a broad upland plateau, generally below 8,000 feet and rather deeply dissected. This plateau is occupied in large part by the Boulder batholith, but Permian rocks are exposed on its eastern and northwestern slopes and are possibly present beneath volcanic rocks on its western side.

The climate is typical of the Northern Rockies. Cold winters alternate with summers mild enough for growing some crops and providing cattle feed. Annual precipitation in the valleys is only a little more than 10 inches but near the mountains it is commonly as much as 15 inches (U.S. Department of Agriculture, 1941). At Elliston it averaged 21 inches over an 11-year period; in the mountains, where it is mostly in the form of snow, it may average considerably more.

Conifers are abundant in most of the mountainous areas, but grassy parks are common. Many peaks are above timberline. The valleys are generally untimbered.

The population outside the major cities is small. Most of the inhabitants live on ranches or in small towns in valleys. Most of those living in the mountains are engaged in occupations related to mining.

\section{GEOLOGIC SETTING}

Rocks of all the geologic eras are exposed in western Montana. The oldest are lower Precambrian crystalline rocks of metamorphic and igneous origin that occupy large areas in the southwestern part of the State and also crop out in a small area in the Little Belt Mountains near Neihart. The crystalline basement rocks are unconformably overlain by the Belt Supergroup, a thick sequence of upper Precambrian sediments which was deposited in a shallow sea that covered the western third of the State and in a large embayment that extended into the central part of the State. Paleozoic and Mesozoic rocks once covered the entire State, although they are now absent in much of western Montana. The older Mesozoic rocks are predominantly marine; the younger ones are partly marine and partly continental and include extensive accumulations of volcanic rock. During the Laramide orogeny at the close of the Mesozoic Era, many of the rocks in the western half of the State were severely deformed and were invaded by magmatic bodies that yielded granitic and volcanic rocks and a large variety of mineral deposits. In post-Laramide time, the region was extensively uplifted and eroded, thick continental deposits accumulated in the basins, and volcanic rocks extended over much of the area.

The area of this report is apparently all underlain by Precambrian sedimentary rocks or by plutonic rocks. The oldest rocks exposed consist of many thousands of feet of the younger Precambrian Belt Supergroup. The Paleozoic rocks are more than 5,500 feet thick in the region of the Philipsburg quadrangle (Emmons and Calkins, 1913; Poulter, 1956; McGill, 1959), where the stratigraphic sequence is typical of western Montana. The Permian strata are thinner in the area of this report than to the south (Swanson, 1970, fig. 172) and are described in the following pages.

The Mesozoic rocks present some unusual features that deserve attention. It is not known whether Triassic seas ever covered this region. That they did might be inferred from similarities between Triassic marine strata to the south, in southwestern Montana, and to the north, in southern British Columbia and Alberta. A thin zone of rocks in an area 3 to 6 miles west of Anaconda has been mapped as Triassic. There, 310 feet of limestone, shale, and sandstone are between the Permian strata and the Kootenai Formation (Lower Cretaceous). Mahorney (1956) assigned them to the Dinwoody Formation of Triassic age, because this sequence of beds is unlike the Jurassic section on the north side of the Flint Creek Range, described by Calkins and Emmons (1915), but similar to sections in the Wise River and Melrose areas to the south, described by Moore (1956) and Fowler (1955) as Triassic. The lower brownweathering limestone that Mahorney described does indeed suggest that found in the Dinwoody elsewhere. However, the gray-weathering limestone at the top, which contains coarse sand, and perhaps the finegrained sandstone underlying it, seem more likely to be of Jurassic age, as do also the upper parts of the sections described by Moore and Fowler. It may be, therefore, that both Triassic and Jurassic strata occur near Anaconda, and that the northern limit of Triassic rocks is north of Anaconda instead of south of it as would be inferred by extension of the line on the maps in the report of Cressman and Swanson (1964). 
In the Philipsburg quadrangle, Calkins (Emmons and Calkins, 1913; see also Calkins and Emmons, 1915) showed the Ellis Formation (Jurassic) underlain by the Quadrant Formation (Pennsylvanian). The Quadrant shown on that map, however, included rocks later assigned to the Amsden and Phosphoria Formations. It may also have included some Jurassic strata. This is suggested by relations exposed on the north side of Gird Creek in sec. 7, T. 8 N., R. $12 \mathrm{~W}$., where a prospect adit has been driven northward along the strike of steeply west-dipping beds of the Retort Phosphatic Shale Member of the Phosphoria Formation. Stratigraphically above the Retort are 35 feet of poorly exposed quartzitic sandstone and shale and 44 feet of covered section which is capped by the "upper quartzite" of Calkins' Quadrant (Emmons and Calkins, 1913, p. 70). The lower beds of this quartzite have oscillation ripple marks on their lower sides and, as noted by Calkins (p. 71), have outcrop properties that differ from those of the "lower quartzite." McKelvey and others $(1959, \mathrm{pl} .3)$ assigned this upper quartzite bed to the upper member of the Shedhorn Sandstone. Pardee (1936, p. 179) had earlier called it the "equivalent of the Rex chert member." In 1959, however, Ellis Yochelson and the writer found poorly preserved fossil fragments that were identified by $R$. W. Imlay (written commun., 1959) as belemnites and Pentacrinus stems of Jurassic age. Imlay also said:

I think that the siliceous sandstone may be an erosional remnant of Bajocian [lower Middle Jurassic] age. *** Bajocian ammonites have been found in reddish-brown siltstone at the base of the Jurassic in the Drummond area. *** similar siliceous sandstone occurs locally at the base of the Jurassic in the front ranges of the Rocky Mountains from the Sun River northward. * * * At Swift Reservoir *** it has furnished a middle Bajocian ammonite. *** the evidence suggests that part of western Montana was covered by a middle Bajocian sea and then was subjected to erosion during late Bajocian and perhaps Bathonian times before most of the Sawtooth formation was laid down. If so the siliceous sandstone would correspond to the Rock Creek member of the Fernie formation $* * *$ and the siliceous cement might have been deposited during an interval of erosion.

Gwinn (1961) mapped the area from the north flank of the Flint Creek Range to the south flank of the Garnet Range. He did not describe in detail the sub-Cretaceous stratigraphy or the distribution of the units, but his table of sedimentary rocks noted 0-150 feet of Shedhorn Sandstone above the phosphatic shale and chert. This probably includes what Imlay regarded as Bajocian sandstone. The thickness of 150 feet was probably found on the north flank of the Flint Creek Range, and the area in which the Shedhorn is absent may be the Garnet Range.

There appear to be two unconformities near the base of the Jurassic, one beneath and the other above the
Bajocian strata. These strata are not present in the Brock Creek area in the eastern part of the Garnet Range.

The deep synclinal trough between the Flint Creek and Garnet Ranges contains a very thick sequence of Cretaceous strata, described by McLaughlin and Johnson (1955), Gwinn (1960, 1961, 1965), and Mutch (1961). The Kootenai Formation, of Early Cretaceous age, is more than 1,000 feet thick. It is overlain by 9,170 to 11,500 feet of rocks in the Colorado Group, consisting of marine and nonmarine sandstone, siltstone, and shale, some conglomerate and limestone, and locally including volcanic debris which is particularly abundant in the upper part of the section (Gwinn, 1960). The Colorado Group is unconformably overlain by an additional 4,000 to 8,000 feet of interlayered sediments, including much coarse conglomerate and volcanic rocks, of Cretaceous age, that Gwinn (1960), Mutch (1961), and Gwinn and Mutch (1965) correlate with the Elkhorn Mountains Volcanics on the east side of the Boulder batholith (Klepper and others, 1957, p. 31).

The Laramide orogeny, after the long period of Paleozoic and Mesozoic sedimentation, produced complicated structure in part of the central western Montana phosphate area, and it was accompanied by extensive igneous activity that culminated in the intrusion of plutonic rocks. The largest pluton is the Boulder batholith, in the eastern part of the area, but many smaller ones are exposed in the Flint Creek and Anaconda Ranges. Large blocks of the crust apparently acted as units and controlled the major development of individual structural features within or adjacent to them during the stages of folding and thrusting. Subsequent igneous intrusion modified much of the earlier pattern. As a result, the Permian rocks, including the phosphate deposits occur in a great variety of structural settings.

The north-trending zone of tight folding and faulting in the southwest Montana synclinorium (Swanson, 1970) apparently divides northward, near Dillon, into two branches separated by the area of the Boulder batholith. The east branch includes the Jefferson Canyon structural complex and the Lombard thrust and fold zone west and north of Three Forks (Robinson, 1959), and apparently connects through the Canyon Ferry area at the Missouri River with the mountainfront "Disturbed Belt" northeast of Helena (Dobbin and Erdmann, 1955). The west branch extends northward from Dillon through the Melrose area and the Flint Creek Range (east of Philipsburg and north of Anaconda) and terminates abruptly near the Clark Fork at the "Lewis and Clark line" of Billingsley and Locke (1941).

The Lewis and Clark line is a lineament that Wallace and others (1960) suggest may have been in existence 
since early Precambrian time. It is one of the larger elements of the tectonic framework of the northern Rockies. It trends about $\mathrm{N} .75^{\circ}-80^{\circ} \mathrm{W}$. and crosses the area described in this report between the Garnet and Flint Creek Ranges; it is expressed as a downwarped or synclinal zone containing strata that range in age from Precambrian to Tertiary. Few large faults have been recognized in it east of Drummond, partly because of an extensive cover of Tertiary sedimentary and volcanic rocks. Many aspects of the geology, however, give evidence of major tectonic significance to this line. These include: (1) an offset in facies of some Permian strata; (2) the unusually thick accumulation of Upper Cretaceous rocks, containing abundant coarse clastic debris of Belt and Paleozoic rocks, in the downwarp between the Flint Creek and Garnet Ranges; (3) the long belt of southeast-plunging en echelon folds along the north side of the lineament, mostly in the Garnet Range; (4) the marked structural discordance between the tight north-plunging folds and associated thrust and normal faults in the Flint Creek Range and the more open southeast-plunging folds in the Garnet Range; (5) east-trending faults at Elliston on which there may have been large lateral displacement; and (6) the blunt northward termination of the Boulder batholith in the vicinity of this lineament.

Abrupt changes in the stratigraphy of the Retort Phosphatic Shale Member of the Phosphoria Formation (Permian) suggest a horizontal offset in facies along the Lewis and Clark line of 15 miles or more, north side eastward. This is comparable with the displacement on the northwest-striking fault system west of Missoula. The changes occur near Drummond between the exposures in the Flint Creek Range to the south and those in the Garnet Range to the north. At the sample localities on the north end of the Flint Creek Range, which are in an area 5 or 6 miles across and nearly due south of Drummond (pl. 30), this member shows little variation in thickness or lithology, or in content and distribution of phosphate (compare lots 1340, 1388, and 1389 of pl. 32). Southwestward toward Philipsburg the member thickens and is less sandy, indicating that the western boundary of the depositional basin must have been much farther west in that latitude. In the Garnet Range near Drummond, only 12 miles north of the northern Flint Creek Range localities, and for 14 miles to the east, the Retort Member is hardly recognizable. (See Pardee, 1917, p. 223; and description of Garnet Range sections of pl. 32 in this report.) At the Anderson mine, however, 15 miles east of Drummond and at other localities still farther east (pl. 32, lots 1287 and 1402), the Retort Member strata are fairly similar to those in the Flint Creek Range. Other explanations for the differences in stratigraphy are possible, but this one is worth introducing for its potential application to the regional structure and its practical bearing on problems of phosphate distribution.

The major tectonic elements noted above were well established during the Laramide orogeny and may be regarded as dividing the area described in this report into five major structural units: (1) the Garnet RangeElliston-Helena area, in the large tectonic block north of the Lewis and Clark line; (2) the Elkhorn Mountains-Three Forks area, south of that line and east of the Boulder batholith; (3) the Boulder batholith; (4) the Flint Creek Range, on the west branch of the southwest Montana synclinorium; and (5) the positive block composed of Precambrian rocks west of the Flint Creek Range.

The Garnet Range-Elliston-Helena area extends along the south flank of a large tectonically high block in northwestern Montana that is occupied mostly by the Precambrian Belt Supergroup. Crustal weakness along the Lewis and Clark line and early uplift of the block north of it (Mutch, 1961), appear to have been instrumental in causing the west branch of the synclinorium to terminate abruptly at the north. Along the south flank of the uplifted block, Paleozoic and Mesozoic formations are exposed in a series of en echelon folds that plunge southeast; Permian strata crop out near the middle of that band of folded strata.

In the Elkhorn Mountains-Three Forks area, the structure is generally synclinal. Paleozoic and Mesozoic formations are folded and thrust faulted to form an arcuate pattern convex to the east.

The Boulder batholith trends north-northeast from south of Butte and is 60 to 70 miles long by 25 to 40 miles wide. Radiometric ages of the Boulder batholith average about $70 \mathrm{~m} . \mathrm{y}$. (Jaffe and others, 1959). Permian rocks are in contact with its east and north flanks and possibly with its west flank. Most of its western boundary is concealed by Tertiary volcanic rocks and by Quaternary deposits in the broad Deer Lodge Valley.

In the Flint Creek Range, the sedimentary formations in the west branch of the southwest Montana synclinorium are tightly folded. They are cut by several thrust faults, some of which are also folded though not as sharply as the beds, and the deformed rocks have been invaded by several bodies of plutonic rock.

The large area of upthrust Precambrian Belt rocks farther west appears to form the western boundary of the synclinorium.

Since Late Cretaceous time, the central western Montana region has remained above sea level, but the sequence of events has varied considerably from one area 
to another. (See especially Pardee, 1950, and Smedes, 1960.) Regional uplift was effected by broad warping and local uplift by block faulting. In some periods, the region was reduced to low or moderate relief; in others, uplift resulted in intensified erosion, and the topography became rugged. Thick deposits of clastic sediments and volcanic flows and pyroclastic rocks accumulated in structural basins and in basins blocked by volcanic materials.

Quaternary warping and block faulting led to the formation of the present pattern of mountain ranges separated by broad basins, and further accentuated the local relief. The higher valleys were modified by alpine glaciation.

\section{REGIONAL STRATIGRAPHY}

Permian sediments were deposited throughout central western Montana, but the rocks have been invaded so extensively by batholiths, or removed by erosion, that they are now present only in areas of general downfolding or downfaulting (pl. 30).

The Permian rocks in the western phosphate field represent three principal stratigraphic facies: (1) chert-mudstone-phosphorite, (2) carbonate rock, and (3) sandstone. These facies intertongue and grade laterally into each other and are assigned respectively to three formations according to lithology. Rocks of the first facies are assigned to the Phosphoria Formation, those of the second to the Park City Formation, and those of the third to the Shedhorn Sandstone (McKelvey and others, 1959). In this area, the stratigraphic sequence and range in thickness of the formations and their members are:

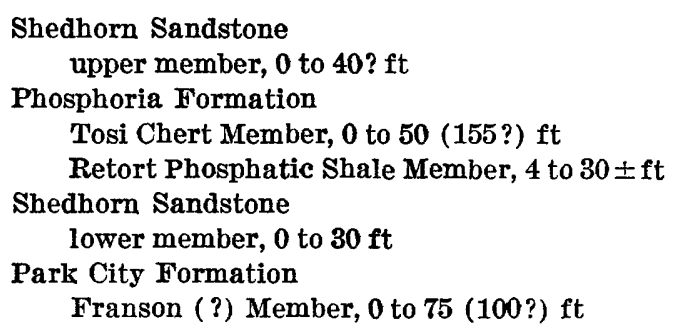

The Permian section rests unconformably on Pennsylvanian rocks assigned to the Quadrant Quartzite and is overlain unconformably by Jurassic rocks and possibly in one area by Triassic rocks. In the Flint Creek and Garnet Ranges, the Permian strata below the Retort Member thin northward (pl. 31), probably chiefly by overlap, which indicates that the time interval represented by the disconformity at the top of the Quadrant was longer in those areas.

The area described in this report contains more than 275 linear miles of exposed or thinly covered Permian strata, much of it in areas so rugged that a large part of the phosphate rock is above entry level (the lowest horizontal access in mining). Some of this phosphate rock, however, has been metamorphosed by the larger intrusive bodies. The only phosphate deposits of commercial value are in the Retort Phosphatic Shale Member of the Phosphoria Formation. The phosphate mineral is carbonate fluorapatite, which occurs mostly in fine to medium-coarse pellets and oolites. The ratio of fluorine to $\mathrm{P}_{2} \mathrm{O}_{5}$ is about 1 to 10 ; fluorine could be recovered as a byproduct in acid treatment of the phosphate rock. The rock also contains a very small amount of uranium; many of the samples analyzed contained more than 0.010 percent equivalent uranium (eU), but none contained as much as 0.020 percent.

\section{PARK CITY FORMATION}

The Park City Formation consists of carbonate strata ranging in known thickness from 0 to 75 feet and possibly as thick as 100 feet. In the Flint Creek Range (pl. 31), its thickness on the north side of Little Gold Creek (near the Moonlight mine, lot 1340, pl. 30) is nearly 75 feet. At that locality it has been metamorphosed by the Philipsburg stock to marble containing much tremolite and talc, but nearly all the strata below the Retort Phosphatic Shale Member of the Phosphoria Formation were well exposed, so the units they represent were clearly identifiable. At Flagstaff Hill in Philipsburg, the strata between the Quadrant Quartzite and the Retort Member are about 100 feet thick and include some cherty limestone (Pardee, 1936, p. 179). Pardee indicated a similar thickness on the north side of Gird Creek, 30 feet of cherty limestone overlying 70 feet of limy sandstone. The writer measured but 55 feet between the Retort and the Quadrant at lot 1387, but only the upper part was exposed (pl. 31). At Douglas Mountain, 2 or 3 miles farther north, Pardee (p. 179) noted that the Quadrant and the Retort are separated by " 40 feet of hard gray limestone containing thin bands of chert." Bell and Moore (1965, p. 71) noted 60 to 120 feet of Park City strata but did not give locations. They stated that "thickness varies erratically."

In the Garrison and Elliston districts, a thinner carbonate layer, which represents a tongue of the Park City Formation, is between the Pennsylvanian Quadrant Formation and the Retort Member of the Phosphoria Formation. At the Graveley mine in the Garnet Range (lot 1286), 5 feet of cherty dolomite representing the top of a tongue of the Park City Formation was observed in the 4,900-level drift; Pardee (1936, p. 179) reported from that area "about 20 feet of chertyappearing rock" between the Quadrant Formation and the phosphate beds. In the Anderson mine (lot 1287), 
nearly 16 feet of soft to hard porous cherty siltstone, which appears to have been cherty limestone leached of its carbonate, is assigned to a tongue of the Park City Formation. This is separated from the Quadrant by a 2-foot tongue of lower Shedhorn Sandstone. Bell and, Moore (1965, p. 71) noted in this district 18 to 41 feet of "lenticular beds of heterogeneously mixed silt, quartzite fragments and non-clastic chert nodules." In the Elliston district (lots 1397, 1398), the Retort Member is underlain by a thin tongue of Shedhorn Sandstone and 2 to 4 feet of cherty carbonate rock representing a tongue of the Park City Formation. The contact' with the Quadrant is not exposed but cannot be more than a few feet below the lowest exposure of carbonate rock.

In the absence of beds that can be correlated with the Meade Peak or the Rex Members of the Phosphoria Formation, the Grandeur and the Franson Members of the Park City Formation cannot be readily differentiated. Those carbonate beds near the base of the Retort probably represent the Franson Member, and perhaps also most carbonate beds between the Quadrant and the Retort in this region.

\section{PHOSPHORIA FORMATION}

The Phosphoria Formation appears to be represented only by the Retort Phosphatic Shale Member and the Tosi Chert Member, although the thin chert in the underlying carbonate rock at Gird Creek may be a tongue of the Rex Chert Member.

\section{RETORT PHOSPHATIC SHALE MEMBER}

The Retort Phosphatic Shale Member consists mostly of phosphorite, but near Philipsburg this member contains much mudstone, and farther north sandstone is common near its top and bottom. The freshest appearing phosphorite is generally dark gray, but most of it is partly weathered and is medium gray to somewhat brownish gray. That exposed near the Anaconda quarry (lot 1337) is dark lustrous gray, and tools and clothes used during sampling became dirty with black dust that looked graphitic. These characteristics may be due in part to metamorphism by nearby intrusive bodies, but they are probably due also to shearing, inasmuch as the phosphatic shale is in fault contact with the Quadrant Quartzite. The basal shale beds are even more strongly sheared and more graphitic looking than the phosphorite. The relatively high content of organic matter shown by analyses of the samples makes it seem unlikely that any true graphite was formed.

Near Melrose (lot 1366), about 20 miles south of the area described in this report, the member is 27 feet thick (pl. 32) ; its upper two-thirds consists chiefly of shaly phosphorite and its lower third of phosphatic shale.
Its thickness near Anaconda (lot 1337) is not known because of faulting, but inasmuch as Anaconda is between the Melrose and the Dissett mine (lot 1386) sections that have similar thicknesses, it is presumably about 25 feet thick. In the Maxville area (lots 1340, 1388, 1389), the member is 10 to 15 feet thick, most loss being due to thinning of the more shaly strata; Pardee (1921, p. 144; 1936 , pl. 34, col. H) reported it to be about 16 feet thick on the slope north of Princeton Gulch. In the eastern Garnet Range, the Retort Member is almost as thick as in the Maxville area, but the phosphorite in the middle part is less diluted by clastic impurities, and mudstone partings are fewer and thinner. In the lower and upper parts of the member, phosphorite intergrades with sandstone, and the member limits are sometimes difficult to define; in most places, however, the basal and top phosphatic sandstone beds are distinctly different from the adjoining rocks, and the basal bed is commonly conglomeratic.

At most localities in this area are beds of sandy phosphorite and phosphatic sandstone at or near the top of the member. These range in thickness from about an inch to nearly 5 feet, and in $\mathrm{P}_{2} \mathrm{O}_{5}$ content from a few percent to more than 24 percent.

The Retort was measured and sampled at 16 localities. At many places all beds were sampled, but at some localities (lots 1285-7, 1337, 1386, and 1401) sampling was restricted mostly to beds rich in phosphate. The averages of all samples from this member in this area (weighted for thickness) are 23.2 percent $\mathrm{P}_{2} \mathrm{O}_{5}, 31.6$ percent acid insoluble, and 9 percent combined carbonate and other acid-soluble components and organic matter. As in southwest Montana (Swanson, 1970, fig. 164), the content of apatite plus acid-insoluble increases northward (fig. 200); it is 85 to 93 percent in the Flint Creek Range, 85 to 97 percent near Elliston, and 94 percent or more in the Garnet Range.

The acid-insoluble components are mainly in sandstone, mudstone, and chert. Sandstone is particularly common in the northern part of this area, and a sixth of the samples are sandstone or are conspicuously sandy; few are very cherty.

The phosphorite in the central western Montana phosphate area consists mainly of small- to mediumsized pellets, but it commonly contains oolites, and in some places they are abundant. Phosphatic shell fragments occur in many places but do not make up a large part of the phosphorite. The sandy zones near the base and top of the Retort Member are commonly nodular, and some of the nodules are very sandy.

\section{TOSI GHERT MEMBER}

The dominantly cherty rocks above the Retort Member represent the Tosi Chert Member of the Phosphoria 


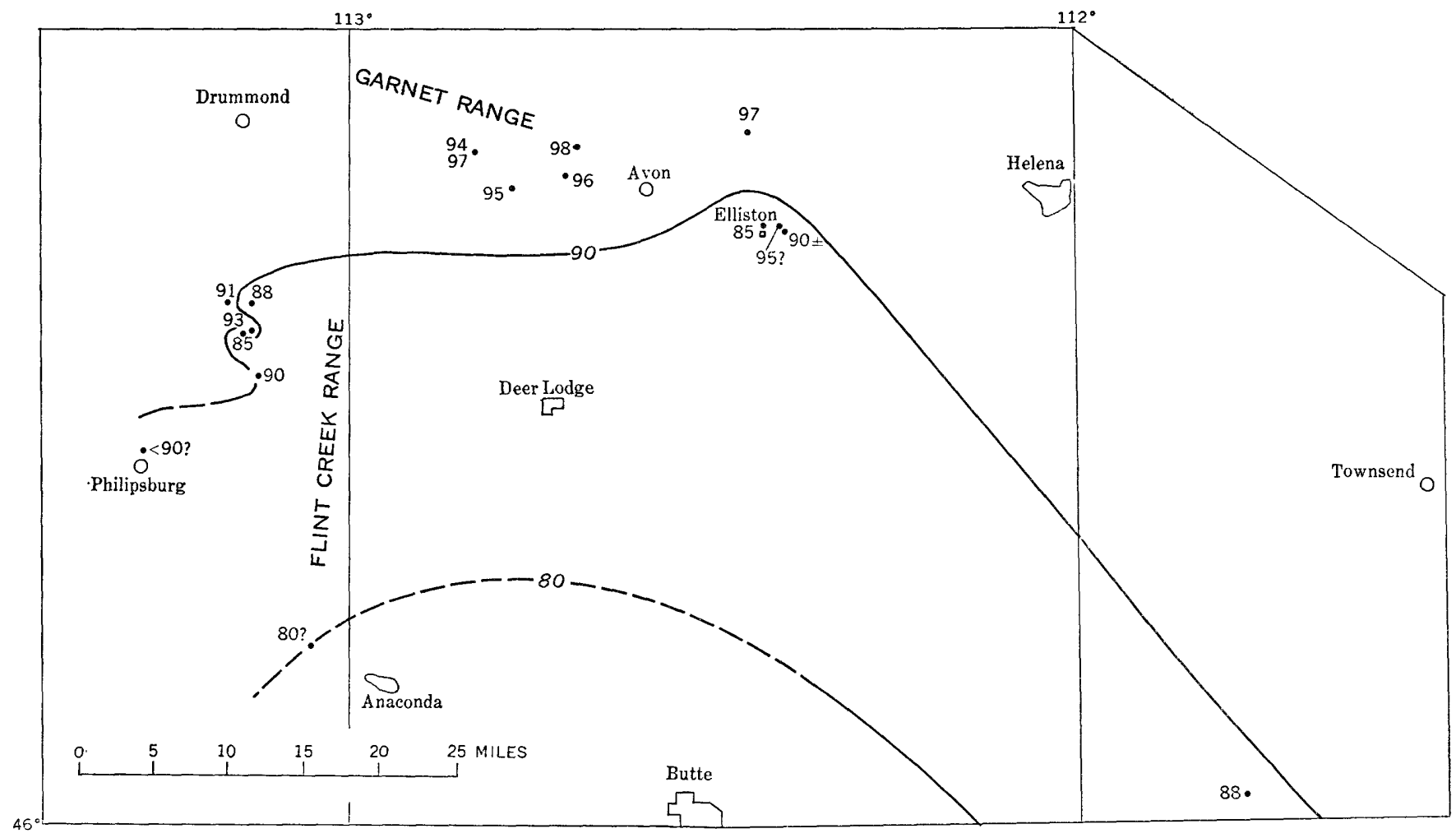

Figure 200.-Percent apatite $\left(\mathrm{P}_{2} \mathrm{O}_{5} \times 2.56\right)$ plus acid-insoluble content of Retort Phosphatic Shale Momber of Phosphoria Formation.

Formation (pl. 31). At the type locality in northwestern Wyoming, the chert is thin bedded. In some parts of this region, it is also thin bedded, but in others it is poorly bedded to massive. The thin-bedded facies seems to be best developed near Elliston; bedding is much less distinct in the Garnet Range.

Stone and Bonine (1914, p. 375) reported that the phosphate in the Elliston area is overlain by 75 feet of soft greenish-brown sandstone and shale, but the writer found it to be overlain by 25 feet or more of chert and quartzite (lots 1397 and 1398). Most of the section above the chert and quartzite is probably of Jurassic age; the contact on plate 31 has been placed arbitrarily 10 feet above the highest measured bed at lot 1397.

Pardee (1917, p. 209) described 0 to 100 feet of "grayish chert" as being exposed in an area "west of Drummond," but in the upper part of the basin of Little Bear Creek, about 3 miles northwest of Bearmouth and 12 miles west-northwest of Drummond, scattered outcrops of typical Shedhorn Sandstone occur in the 50- to 75foot interval between outcrops of Quadrant Quartzite and the Ellis Group.

In the Flint Creek Range area, the Tosi Chert Member apparently is not well developed. Three feet of somewhat sandy chert (probably $<20$ percent sand) was found near Little Gold Creek (lot 1340), but at most of the sample localities no chert was found above the Retort Member.

In the area west of Anaconda, Mahorney (1956) measured 155.5 feet of "black and dark gray massive chert," an unusual thickness for the Tosi Member anywhere and the more so inasmuch as only 40 feet of sandstone was found above the Retort Member at Anaconda quarry (lot 1337) only 3 miles away.

Most of the chert in the area of this report is sandy, and sand is abundant in some. Some of the chert contains sponge spicules that are clearly recognizable in hand specimens. The chert beds are not generally as dark as they are farther south; their lighter color is probably due in part to extensive mid-Tertiary weathering, but it is also believed to indicate that the chert contains less carbonaceous matter.

\section{SHEDHORN SANDSTONE}

Tongues of both the lower and the upper members of the Shedhorn Sandstone are present in the Flint Creek and Garnet Ranges (pl. 31). Most of the Shedhorn Sandstone is fine grained, and much of it is quartzitic. The quartzitic character seems to be related in some places to hydrothermal activity (lot 1402) and in other places to mid-Tertiary weathering. The lower member 
is represented in the Flint Creek Range and most of the Garnet Range by a thin layer of sandstone, although it comprises as much as 30 feet of cherty quartzite at Warm Springs Creek in the Garnet Range (lot 1402). The upper member is a little more than 40 feet thick near Anaconda (lot 1337), where it represents the entire Permian section above the Retort Member. The member is also prominent at Gird Creek (lot 1387) near Maxville, where 35 feet of quartzitic sandstone is interbedded with soft sandy shale, and at the Graveley mine (lot 1286) in the Garnet Range. Bell and Moore $(1965$, p. 70,71$)$ did not recognize any Shedhorn in the Garrison district, but they noted that a "thin but persistent cherty quartzite lies at top immediately below phosphate bed" and that the Tosi Member "becomes quartzitic toward base $* * *$ and beyond 'shoreline' becomes sandstone." Quartzitic sandstone was seen by the writer west of Drummond, but exposures were not sufficient for measurement of a section. (See description of that area, p. 798.) Bell and Moore (1965, p. 71) stated that the phosphate bed north of the Clark Fork (presumably near Drummond) "is overlain by soft sandstone rather than chert or cherty quartzite."

\section{ECONOMIC GEOLOGY}

Phosphate is the only major resource in the Permian rocks of the central western Montana phosphate field. Carbonate fluorapatite, however, contains fluorine in the approximate ratio of 1 percent fluorine to each 10 percent $\mathrm{P}_{2} \mathrm{O}_{5}$, and uranium in the approximate ratio of 0.001 percent uranium to each 3 percent $\mathrm{P}_{2} \mathrm{O}_{5}$ (Altschuler and others, 1958). Other elements that are present in very small quantity in phosphatic shales (Gulbrandsen, 1966) might also be of economic value.

\section{PHOSPHATE}

The western phosphate field is one of the largest in the world. Its phosphorus is contained in carbonate fluorapatite. Most of the mined phosphate rock is used for making fertilizer by sulfuric-acid treatment of rock containing more than 31 percent $\mathrm{P}_{2} \mathrm{O}_{5}$ and for recovering phosphorus in the elemental state by electricfurnace treatment of rock containing about 24 percent $\mathrm{P}_{2} \mathrm{O}_{5}$. The rock is generally mined at about the grade needed for treatment, but the grade is sometimes modified by blending or beneficiation. Some of the phosphate rock is applied directly as a fertilizer to acid soils without being treated, and some is treated for removal of fluorine and used as an animal-feed supplement.

The phosphate is in layers or beds mixed with other rock materials (pl. 32). In some layers, the phosphate mineral is the dominant component (pl. 33) ; it represents more than 95 percent of the total rock $(>37.2$ percent $\left.\mathrm{P}_{2} \mathrm{O}_{5}\right)$ in a few sampled beds. In others, the phosphate is much diluted with mud or sand, or those components may dominate. The various rock types are interbedded, particularly phosphorite and mudstone, and few layers in the phosphatic shale member anywhere are as thick as 2 feet. Mudstone and phosphorite are commonly interlaminated.

All the phosphate rock mined in central western Montana occurs in the Retort Phosphatic Shale Member of the Phosphoria Formation. In the eastern part of the Garnet Range, most of the phosphate is in a single zone of high-grade phosphate rock only 3 to 5 feet thick (pls. 32, 33), which is separated from the underlying lower Shedhorn tongue by a thin layer of phosphatic conglomerate and overlain by a few feet of phosphatic sandstone. The phosphate zone pinches out in the western part of the range. To the east, in the Elliston area, the phosphate rock thins and is of lower grade because it contains more shaly partings, but the sandstone above it is more phosphatic and partly minable.

In the northern part of the Flint Creek Range (pl. 32 ), the main phosphate zone, at or near the top of the Retort Member, has about the same thickness as in the eastern part of the Garnet Range area, but it contains numerous shaly partings. On top of the main phosphate zone at the east adit of the Edgar mine is $31 / 2$ feet of sandy phosphorite containing more than 24 percent $\mathrm{P}_{2} \mathrm{O}_{5}$. The area of such quality and thickness is probably small.

Near Philipsburg, the phosphate zone is thicker and more shaly than it is in the northern part of the Flint Creek Range, and the underlying phosphatic shale is about 12 feet thick. The basal phosphorite is about 1 foot thick and overlies a bed of phosphatic conglomerate.

Near Anaconda, the upper part of the Retort Member has the same character that it has near Philipsburg; where sampled the lower part is absent because of faulting.

The approach to reserve classification and the use of the terms "reserves" or "resources" have been discussed by Swanson (1970). Phosphate zones used in tonnage estimates are defined as follows: (1) minimum grades are 31,24 , or 18 percent $\mathrm{P}_{2} \mathrm{O}_{5}$ (high grade, medium grade, and low grade, respectively) ; (2) zones must be 3 feet thick; (3) where a sequence of beds above the given minimum grade is a little less than 3 feet thick, a part of an adjacent bed is added to increase the total to 3 feet, provided that the combined total contains the minimum grade; (4) the uppermost and lowermost beds in a zone contain no less than the minimum grade for that zone, except where the third rule is applied; (5) no zone includes a sequence 3 feet thick of beds containing less than the minimum grade for that zone. Tonnage 
factors for the three grades noted above are 11.0, 11.5, and 12.0 cubic feet per ton. Computed tonnages are rounded to the nearest 5 of the second significant figure, and no tonnages of less than 50,000 tons are recorded. All estimates are in short tons.

Estimates of tonnage and grade are based on analyses of samples collected in this study and on data published by Pardee $(1913,1917,1921$, and 1936) and by Stone and Bonine (1914). They take account of the thickness of each bed and also of its area in the plane of bedding, all of which are recorded in the tables given in this paper.

The bed areas were obtained by constructing maps showing 1,000-foot structure contours at the base of the Retort Member. The information available for construction of these contours is of widey varying quality. The figures for tonnages above entry level, or even within 2,000 or 3,000 feet below it, seem in general to be fairly satisfactory, but they become progressively uncertain with increasing depth.

The central western Montana phosphate field is calculated to contain about 600 million tons of high-grade, nearly 2 billion tons of medium-grade, and more than $21 / 2$ billion tons of low-grade phosphate rock $(31,24$, and 18 percent $\mathrm{P}_{2} \mathrm{O}_{5}$, respectively). These tonnages represent 23,67 , and 82 percent of the 840 million tons of $\mathrm{P}_{2} \mathrm{O}_{5}$ in the area. The three grades of rock are also estimated to contain about 19, 55, and 70 million tons, respectively, of uranium.

The Garnet Range contains more than half the highgrade phosphate. The Flint Creek Range contains onethird of the high-grade, two-thirds of the mediumgrade, and three-fourths of the low-grade phosphate, or nearly three-fourths of the $\mathrm{P}_{2} \mathrm{O}_{5}$ in the area.

Only a small part of the total phosphate resources of this area could be recovered under present economic and technologic conditions. Most of the phosphate of this area is at too great a depth to be minable. Less than 10 percent of each of the three grades of rock occurs above entry level, and less than 18 percent of the high-grade phosphate occurs at depths less than 500 feet below this level. Some of the deposits are too high or are too remote from transportation to be mined in the near future.

Part of the "available" phosphate is spoiled for mining by structural complications, especially by closely spaced cross faults. Where these have been recognized, they were allowed for in calculating tonnages. Some of the phosphate near the plutonic intrusive bodies may also be difficult to mine or to treat because of metamorphic effects. Other geologic factors affecting recoverability of phosphate include character of footwall and hanging-wall rocks, dip, bedding, and ground-water conditions.
Most of the mining in the western phosphate field had been done underground until the last few years. Much of that in Idaho, Wyoming, and Utah is now done by stripping, but in Montana, most phosphate is still mined underground, although a small tonnage has been strip mined at the Anderson mine (Mining World, 1955; Popoff and Service, 1965, p. 30). Strip mining has the advantage of lower costs, including smaller investment in mine and equipment, but it can be used only where the overburden is rather thin and easily removed. In Montana, the phosphorite is rarely more than 5 feet thick, and much of it is overlain by a great thickness of relatively hard rocks.

\section{URANIUM}

All the western phosphorite contains uranium, though always in very small quantity. Altschuler, Clarke, and Young (1958) have discussed the geochemistry of uranium in phosphorite, and Sheldon (1959) has discussed it with special reference to the Phosphoria Formation. The distribution of uranium in rocks of the Phosphoria Formation of southwest Montana was described by Swanson (1970); what follows relates especially to its occurrence in rocks of the Phosphoria in central western Montana.

Uranium content can be approximately estimated by measuring radioactivity, of which uranium is the major source, but each 2 percent of $\mathrm{K}_{2} \mathrm{O}$ is equivalent to about 0.001 percent of eU (Swanson, 1970, fig. 194). Shales contain, on the average, about $31 / 4$ percent $\mathrm{K}_{2} \mathrm{O}$ (Clarke, 1924, p. 30). Some of the shale beds in the Meade Peak Member of the Phosphoria Formation at Coal Canyon, Wyo., contain as much as 5 percent $\mathrm{K}_{2} \mathrm{O}$, but the radioactivity due to $\mathrm{K}_{2} \mathrm{O}$ probably does not exceed 0.002 percent $\mathrm{eU}$ in any of the samples from the area described in this report.

Almost all the 144 samples from this area were analyzed both chemically and radiometrically for uranium. That the uranium and its daughter products are essentially in equilibrium is indicated by the near agreement of chemical and equivalent uranium values for most of the samples (fig. 201). Samples collected and analyzed before 1949 are likely to be low in chemical uranium (Cressman and Swanson, 1964, p. 280). The samples from lots 1285, 1286, and 1287 were collected in 1948; most of them have lower chemical values, and of all the samples for which the values differed by more than 0.002 percent, half were from these three localities. Because of this, the equivalent uranium values $(\mathrm{eU})$ are used in comparisons with $\mathrm{P}_{2} \mathrm{O}_{5}$ in this report.

None of the samples contains as much as 0.020 percent equivalent uranium, but 3 in 10 contain at least 0.010 percent. In general, the uranium content of the Phosphoria strata is roughly proportional to the $\mathrm{P}_{2} \mathrm{O}_{5}$ 


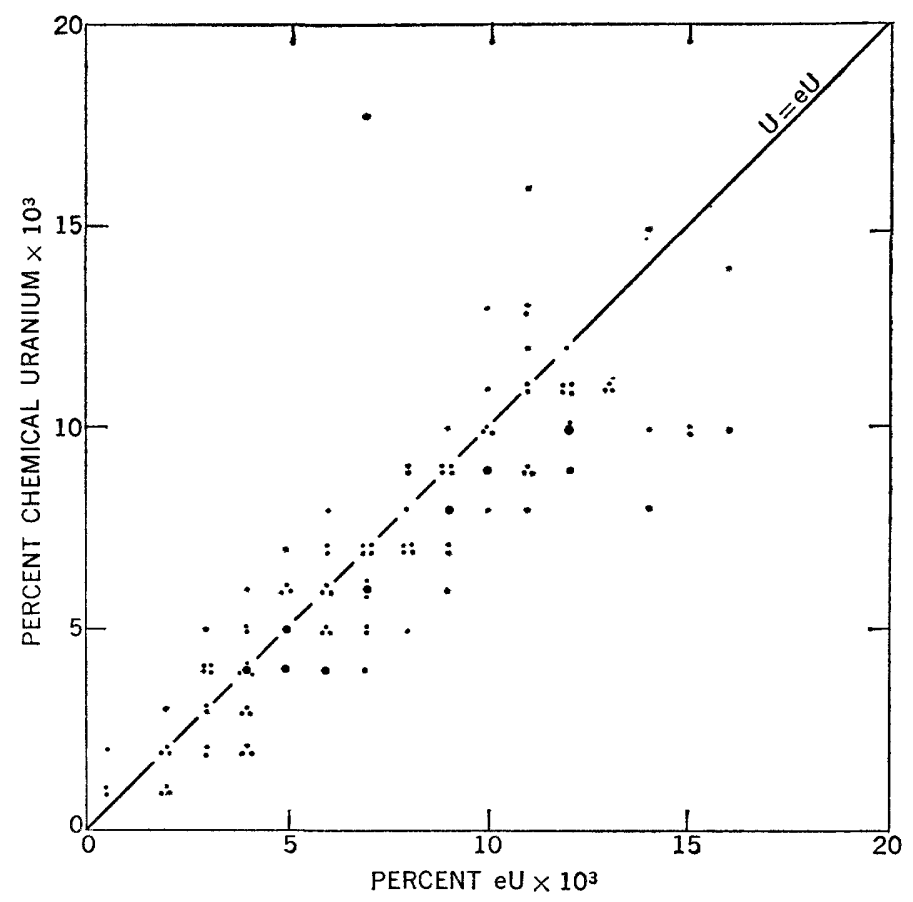

FIGURe 201.-Chemical and equivalent uranium in samples from central western Montana. Large dots represent five samples. content (McKelvey, 1956; Sheldon, 1959; Swanson, 1970). Figure 202 tends to bear this out, though not as clearly as the diagrams for Wyoming given by Sheldon (1959, figs. 13, 14, and 15) and for southwest Montana by Swanson (1970, figs. 192, 193). The ratio is roughly $\mathrm{eU}: \mathrm{P}_{2} \mathrm{O}_{5}=1: 3,000$. Many of the points plotted in figure 202 differ considerably from this, but the differences balance out.

In the phosphate zones of minable thickness and grade, the eU content ranges from 0.004 to 0.015 percent and averages about 0.009 percent (fig. 203). Except for the samples collected in 1948, which are consistently low in reported uranium and probably have an analytical bias, all zones show a difference between $\mathrm{eU}$ and $\mathrm{U}$ of less than 0.002 percent, and 60 percent of them contain more eU than U. In half the zones, the average eU content falls within 0.001 percent of the trend line shown in figure 202 , and in nearly half of the remainder within 0.002 percent.

The average $\mathrm{eU}$ contents for the zones having $\mathrm{P}_{2} \mathrm{O}_{5}$ cutoffs of 31,24 , and 18 percent are $0.0110,0.0083$, and 0.0082 percent, respectively. The average for all zones is 0.0089 percent.

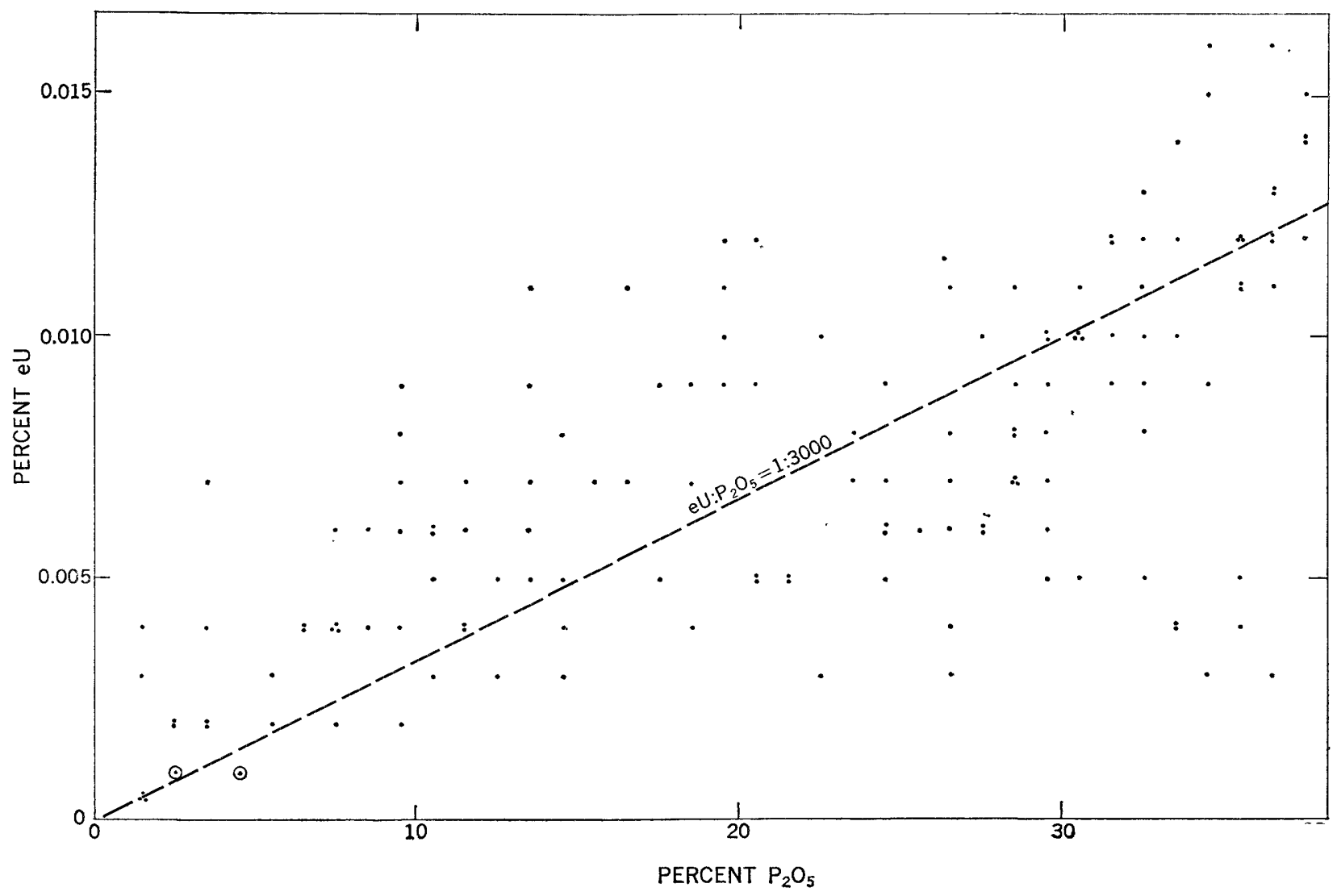

FIGURE 202.- $\mathrm{P}_{2} \mathrm{O}_{5}$ and equivalent uranium in samples from central western Montana. $\odot$, Chemical uranium, no eU reyort a vailable. 

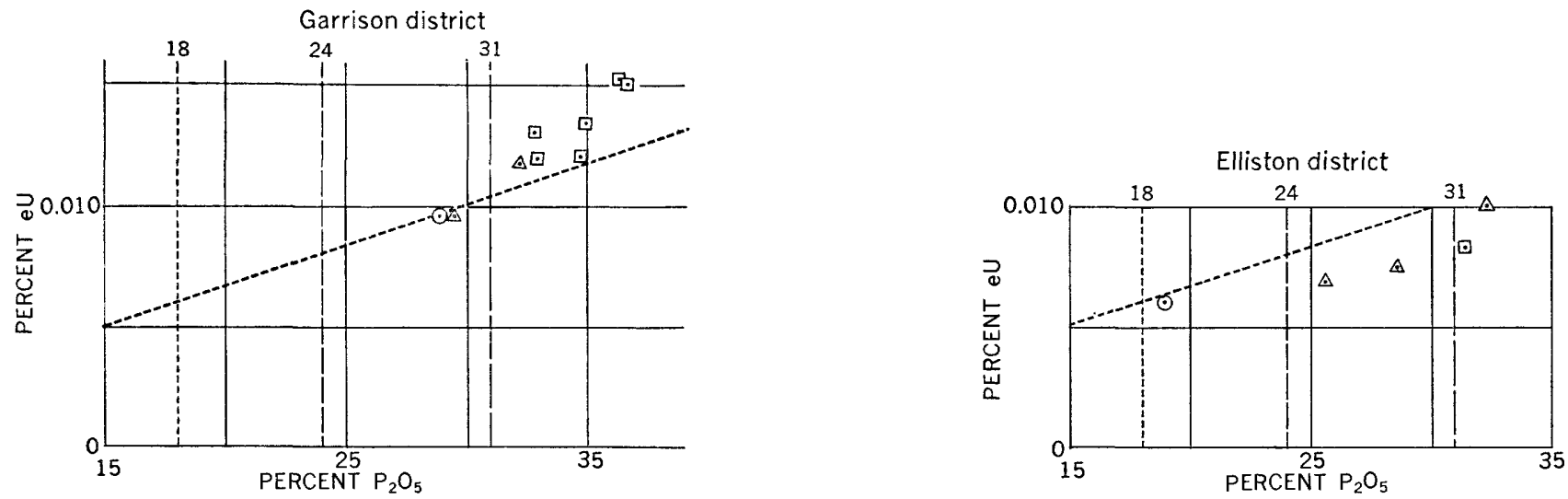

EXPLANATION
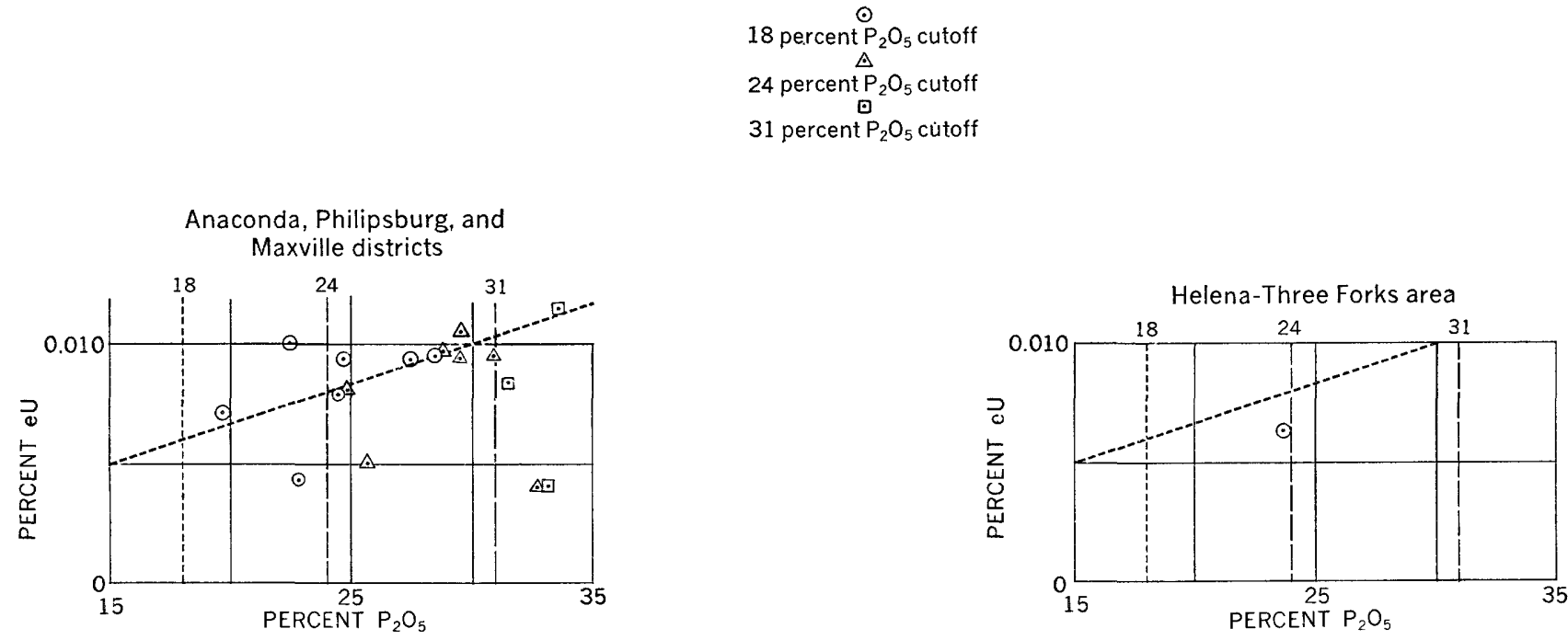

FIGURE 203. $-\mathrm{P}_{2} \mathrm{O}_{5}$ and equivalent uranium in phosphate zones in central western Montana. Dotted line, $\mathrm{e} U: \mathrm{P}_{2} \mathrm{O}_{5}=1: 3,000$.

At six localities, all underground, it is believed that leaching out of uranium or enrichment in uranium by ground water has taken place. The evidence for leaching is clearest at the Moonlight and Dissett mines (lots 1340 and 1386, fig. 204). At these localities, the four phosphate zones have the four lowest eU values in the Anaconda, Philipsburg, and Maxville districts (fig. 203). At the Moonlight mine, the weathered condition of the Retort Member is apparent from its generally light color, the friability of much of its phosphorite, and the soft, clayey condition of its mudstones. The mudstones are for the most part medium to light brownish gray but contain thin layers of yellow, red, and light-gray material, and those underlying the main phosphate zone are extremely soft. The eU content of all samples from the Moonlight mine is very low, ranging from 0.003 to 0.005 percent, and shows no consistent relation to the phosphate content. The $\mathrm{U}$ content is also low but averages about 0.001 percent higher than $\mathrm{eU}$, a fact that may indicate differential leaching of the uranium and its daughter products.

At the Dissett mine (lot 1386), on Red Hill at the north side of Philipsburg, Permian rocks are preserved in the axial part of a rather tight syncline and do not extend far below the surface; the rest of the hill is composed of Quadrant Quartzite. The Permian rocks are deeply weathered, as is shown by the light color and softness of the mudstones, the medium grays of the phosphorites, and the heavy white phosphate "bloom" on the joint planes of the quartzitic basal conglomerate. The phosphate pellets disseminated through the mudstones are also light gray to white. The Park City Formation underlying the Retort Member has been leached of much of its carbonate and is now very soft. Both the $\mathrm{U}$ and the eU contents of the phosphatic samples from the Dissett mine are very low, and they seem to bear 


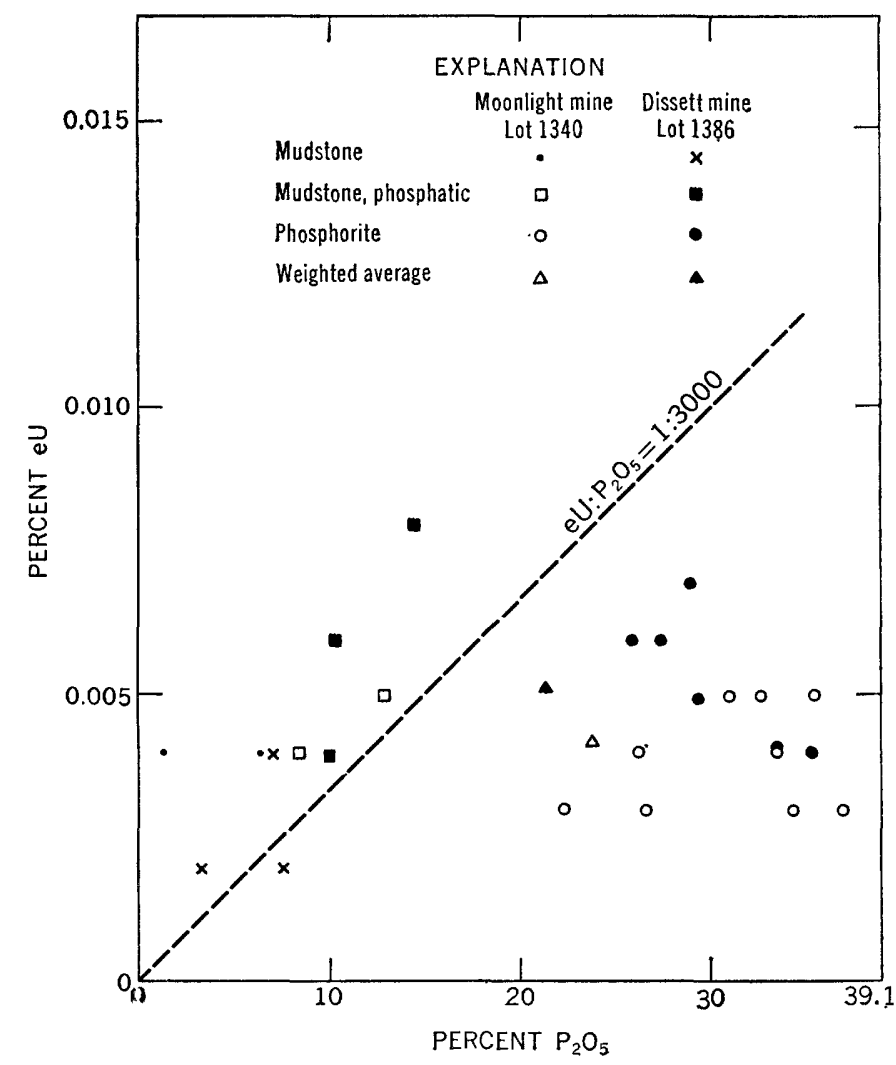

Figure 204.- $\mathrm{P}_{2} \mathrm{O}_{3}$ and equivalent uranium in samples from lots 1340 and 1386, Maxville and Philipsburg districts.

little relation to the $\mathrm{P}_{2} \mathrm{O}_{5}$ content. Varying amounts of uranium thus appear to have been leached from these rocks.

The samples taken from the Douglas Creek mine in the Flint Creek Range (lot 1388) and from the Graveley mine in the Garrison district (lot 1286) contain more than normal eU. At both localities they were collected at some distance underground and may be secondarily enriched. The distance of the water table below the sampling localities is not known but is probably small. In the samples from the Anderson and Luke mines in the Garrison district (lots 1287 and 1285), the eU content is a little above normal. Some of the rocks close to the surface at the Anderson mine appear to be weathered, but their eU content is not known. Although the evidence for enrichment is not generally as clear cut as that for leaching, some enrichment apparently occurred at most of these localities.

\section{FLUORINE}

The phosphate mineral throughout the western phosphate field is carbonate fluorapatite, which contains about 1 part fluorine for every 10 parts $\mathrm{P}_{2} \mathrm{O}_{5}$. Fluorine can be recovered as a byproduct in the acid treatment of phosphate rock, and in fact some has been so recovered for plant use at Trail, British Columbia, from phosphate rock mined north of Garrison (C. O. Swanson, oral commun., 1951).

Fluorite has been recognized at some localities in this area. It is usually not abundant, but at Warm Springs Creek north of Garrison (lot 1402), it is common in small veinlets that cross the phosphorite. The somewhat vuggy fluorite forms crystals about $2 \mathrm{~mm}$ in diameter, which are generally dark bluish purple where fresh but become colorless when weathered. The phosphorite at this locality is hard and flinty and appears to have been silicified; its acid-insoluble content (20 percent) is notably higher at this locality than at others nearby. These features are apparently due to hydrothermal activity, the waning stages of which are responsible for the travertine terraces forming in the valley nearby. It seems likely that much if not all this fluorite was formed from fluorine leached from phosphorite at depth by ascending water, and the abundant fluorite is probably of very local occurrence.

The $\mathrm{F}: \mathrm{P}_{2} \mathrm{O}_{5}$ ratio of most of the phosphorite in central western Montana is fairly constant; in each million tons of phosphorite there is approximately a thousand tons of fluorine for each 1 percent of $\mathrm{P}_{2} \mathrm{O}_{5}$. The total fluorine in rock within this report area containing 31 , 24 , and 18 percent $\mathrm{P}_{2} \mathrm{O}_{5}$ would thus be 19,54 , and 71 million short tons, respectively.

\section{GEOLOGY OF PHOSPHATE DEPOSITS}

The phosphate deposits described in this report are divided into five districts: the Anaconda, Philipsburg, Maxville, Garrison, and Elliston. Two other areas that contain resources but that have no history of mining are described, the Pendant syncline and the HelenaThree Forks area. These districts and areas are shown on plate 30 .

\section{ANACONDA DISTRICT}

The Anaconda district includes several small synclines and fault blocks near Warm Springs Creek, in T. 4 and 5 N., R. 12 W. (pl. $34 A$ ). Permian rocks also crop out in two areas north of Anaconda and in one on the southeast side of the Mount Powell stock; these areas are all near the west edge of the Deer Lodge Valley. Permian rocks occur also in a syncline between the Mount Powell, Royal, and Philipsburg stocks.

As the small fault blocks near Warm Springs Creek are in the 8-mile gap between the Mount Powell stock and the intrusive bodies in the Anaconda Range, they probably make up a relatively thin pendant above a composite intrusive body which, to judge from the large number of dikes in this area, is not very far below the surface. Such a condition is further indicated by the many small variously oriented faults and by the lowgrade metamorphism common in this area. 
In the area north of Warm Springs Creek, T. 5 N., R. $12 \mathrm{~W}$., are four small fault blocks; two are in secs. 23 and 24 (lot 1337), one in secs. 8, 16, and 17, and one in secs. 5 and 6 . At the locality identified as lot 1337 (table $1 ;$ pl. 33) furnace-grade phosphate rock at the top of the Retort Member is about 7 feet thick and contains about 6 percent combined $\mathrm{Al}_{2} \mathrm{O}_{3}$ and $\mathrm{Fe}_{2} \mathrm{O}_{3}$. A nearbedding fault in the lower part of the zone repeats part of the section. The shale underlying the phosphate zone is considerably sheared, and the lower half to two-thirds of the Retort Member plus all the Park City Formation is cut out by a large near-bedding fault. The phosphate in the two northwestern blocks may have been adversely affected by heat from nearby intrusive bodies. The total phosphate resources of this area (fig. 205) must therefore be relatively small.

TABLE 1.-Measured section and anaylses of Permian rocks near Anaconda quarry, Montana, lot 1337

[Section measured and described by R. W. Swanson and sampled by R. A. Zeller, August 1950, in hand trench and natural exposures on north side of Warm Springs Creek, about a quarter of a mile east of Anaconda limastone quarry, SE $1 / 4$ sec. 23, T. 5 N., R.12 W', Doer Lodge County, Mont. Beds strike N. $75^{\circ}$ E. and dip $25^{\circ}$ N. Samples nalyzed for $\mathrm{P}_{2} \mathrm{O}_{5}$ and acid insoluble by U.S. Bur. Mines and for other constituents by U.S. Geol. Survey. LOI, loss on ignition]

Bed Thickness

Upper Tongue of Shedhorn Sandstone, top not exposed:

US?-16_- 5. $0+$ Covered at top of cliff, but pale-yellowishorange $(2.5 Y 9 / 4)$ quartzite is exposed some distance back from cliff.

US-15._- 3.8 Quartzite: hard, light-brownish-gray $(10 Y R 6 / 1)$, fine- to medium-grained one bed.

14_-_ 28. 7 Quartzite: hard, medium-gray $(N 6)$ to yellowish-gray $(10 Y R$ 7/1), thickbedded to massive, fine-grained.

13..- 7. 7 Quartzite: hard, yellowish-gray (10YR $7 / 1)$, thin- to thick-bedded, finegrained.

Retort Phosphatic Shale Tongue of Phosphoria Formation, upper part only:

Rt-12... 0.8 Quartzite: phosphatic, hard, light-brownish-gray $(10 Y R 6 / 1)$, fine-grained grades from hard brownish-gray (10YR 4/1) finely pelletal sandy phosphorite in basal 0.1 foot; one bed; basal contact irregular.

11._. . 9 Phosphorite: soft, crumbly, dark-gray $(N 4)$, bedding indistinct, finely pelletal; unit brecciated.

10_._ . . 9 Phosphorite: muddy, especially in upper half, soft to hard, dark-gray $(N 3)$,

thin-bedded, finely to coarsely pelletal
9._. 6 Phosphorite: medium-hard, dark-gray $(N 3)$, thin-bedded, partly pelletal.

8... . . 9 Mudstone: phosphatic, soft to hard, black to dark-gray $(N 3)$, finely pelletal; basal contact irregular.

7... . 4 Mudstone: phosphatic, carbonatic (?), soft, grayish-brown (7.5YR 4/2), thinbedded; grades from medium-hard darkgray $(N 3)$ thin-bedded finely pelletal muddy phosphorite in basal $0.1 \mathrm{ft}$; basal contact irregular.

6... 1.8 Phosphorite: medium-hard to hard, grayish-black $(N 2)$ to dark-gray $(N 3)$, thin-bedded, finely pelletal; top 0.2 ft sheared and soft to crumbly.
Retort Phosphatic Shale Tongue of Phosphoria Formation, upper part only-Continued

Rt-(5)__ (.5) Phosphorite: muddy, soft to crumbly, dark-gray $(N 3)$, finely pelletal; sheared; equals upper part of bed 5 (sample 5893).

Fault, diagonal, with repetition of strata.

Rt-(6)... (1.2) Phosphorite: hard, dark-gray (N 3), laminated, finely pelletal; sheared; equals lower part of bed 6 (sample 5896).

5._. 1.2 Phosphorite: muddy, medium-hard, grayish-black ( $N 2)$; strongly sheared; basal contact irregular.

4... 1. 0 Mudstone: phosphatic, hard, black ( $N 2$ ) to pale-brown $(10 Y R 5 / 3)$; sheared; may be cherty in part; basal contact irregular.

3... 6 Mudstone: carbonatic, medium-hard, medium-dark-gray ( $N$ 4) to mediumlight-gray $(N 6)$, poorly bedded; basal contact sheared.

2... 6 Mudstone: carbonatic, medium-hard, dark-gray ( $N 3$ 3); contains considerable phosphate; basal contact sheared and irregular.

Fault. Lower part of Retort Member and all underlying Permian rocks missing.

Quadrant Quartzite:

Q-1___ 10.0 Quartzite: hard, very pale brown (10YR $7 / 2)$ to medium-gray ( $N 5)$, darker upward, massive, fine-grained. Prospect pit below contains some mineralization and is iron stained.

\begin{tabular}{|c|c|c|c|c|c|c|c|c|c|c|}
\hline \multirow{2}{*}{ Bed } & \multirow{2}{*}{ Samplo } & \multirow{2}{*}{$\begin{array}{c}\text { Thickness } \\
\text { (feet) }\end{array}$} & \multicolumn{6}{|c|}{ Chemical analyses (percent) } & \multicolumn{2}{|c|}{$\underset{\text { (percent) }}{\text { Uranium content }}$} \\
\hline & & & $\mathrm{P}_{2} \mathrm{O}_{5}$ & $\mathrm{Al}_{2} \mathrm{O}_{3}$ & $\mathrm{Fe}_{2} \mathrm{O}_{3}$ & LOI & $\begin{array}{c}\text { Acid } \\
\text { insoluble }\end{array}$ & $\begin{array}{l}\text { Organic } \\
\text { matter }\end{array}$ & $\mathrm{eU}$ & $\mathrm{U}$ \\
\hline 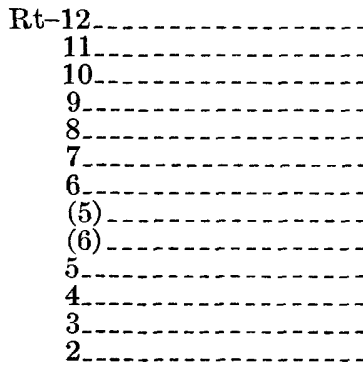 & $\begin{array}{l}\text { 5902-RWS } \\
\text { 5901-RWS } \\
\text { 5900-RWS } \\
\text { 5899-RWS } \\
\text { 5898-RWS } \\
\text { 5897-RWS } \\
\text { 5896-RWS } \\
\text { 5895-RWS } \\
\text { 5894-RWS } \\
\text { 5893-RWS } \\
\text { 5892-RWS } \\
\text { 5891-RWS } \\
\text { 5890-RWS }\end{array}$ & $\begin{array}{r}0.8 \\
.9 \\
.9 \\
.6 \\
.9 \\
.4 \\
1.8 \\
(.5) \\
(1.2) \\
1.2 \\
1.0 \\
.6 \\
.6\end{array}$ & $\begin{array}{l}18.4 \\
29.0 \\
26.6 \\
32.8 \\
11.8 \\
14.0 \\
30.2 \\
19.2 \\
30.6 \\
19.3 \\
10.0 \\
3.9 \\
7.2\end{array}$ & $\begin{array}{l}\text { 1. } 48 \\
1.87 \\
4.68 \\
1.28 \\
9.12 \\
9.96 \\
3.25 \\
\text { 7. } 30 \\
3.60 \\
\text { 7. } 92 \\
10.9 \\
14.8 \\
11.6\end{array}$ & $\begin{array}{l}1.41 \\
2.23 \\
1.02 \\
.68 \\
\text { 1. } 23 \\
\text { 7. } 93 \\
1.25 \\
2.80 \\
1.45 \\
3.35 \\
4.54 \\
7.52 \\
12.1\end{array}$ & $\begin{array}{r}0.94 \\
2.55 \\
6.79 \\
4.96 \\
12.66 \\
13.68 \\
7.79 \\
16.52 \\
10.72 \\
16.36 \\
20.08 \\
20.54 \\
25.16\end{array}$ & $\begin{array}{r}48.7 \\
6.3 \\
20.1 \\
10.5 \\
45.7 \\
30.1 \\
11.1 \\
24.7 \\
10.8 \\
25.6 \\
44.1 \\
46.7 \\
39.1\end{array}$ & $\begin{array}{r}0.27 \\
.35 \\
.94 \\
.65 \\
\text { 1. } 82 \\
1.42 \\
.53 \\
3.12 \\
\text { 1. } 34 \\
\text { 1. } 45 \\
3.52 \\
\text { 5. } 44 \\
\text { 4. } 51\end{array}$ & $\begin{array}{r}0.007 \\
.011 \\
.011 \\
.008 \\
.007 \\
.007 \\
.010 \\
.011 \\
.011 \\
.009 \\
.008 \\
.004 \\
.004\end{array}$ & $\begin{array}{r}0.006 \\
.013 \\
.008 \\
.009 \\
.005 \\
.007 \\
.013 \\
.013 \\
.016 \\
.008 \\
.005 \\
.006 \\
.004\end{array}$ \\
\hline
\end{tabular}




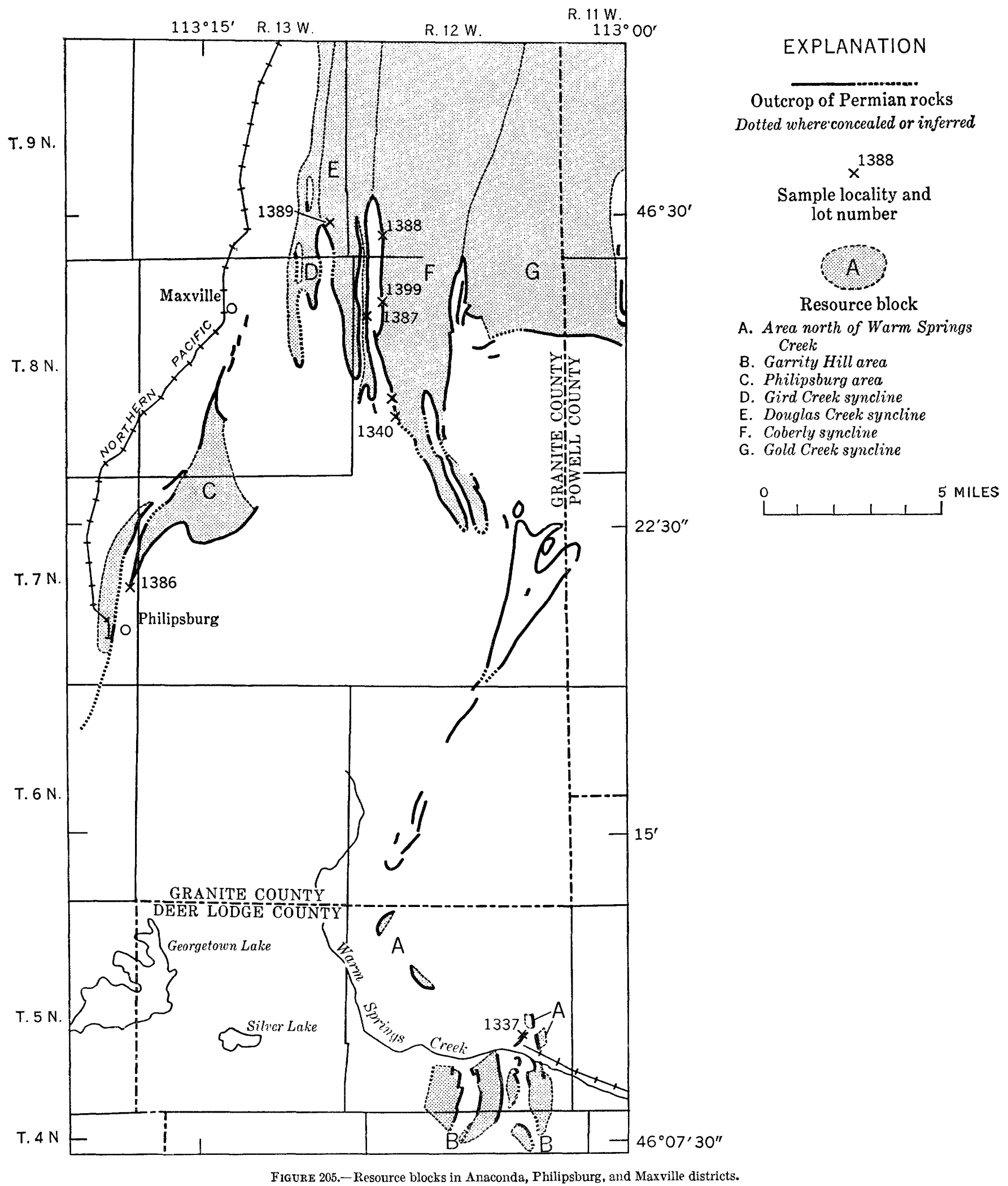


The area south of Warm Springs Creek containing outcrops of Permian rocks (pl. 34A) was first mapped by Calkins (Emmons and Calkins, 1913) and later mapped in more detail by Mahorney (1956), who called it the Garrity Hill area. It is in a structurally depressed part of the crustal segment between the Mount Powell stock and the intrusive bodies of the Anaconda Range, and it is now surrounded and partly covered by Tertiary gravel, glacial deposits, and postglacial alluvium.

Permian rocks exposed in this area are on the flanks of two anticlines that strike about north. These folds are overturned toward the east and their limbs are steep. The folded rocks are also broken by many faults, which belong to at least three groups: (1) near-strike reverse faults dipping moderately to steeply west; (2) near-strike east-dipping normal faults; and (3) steep faults, generally of small displacement, about normal to the beds.

The Permian rocks occur in four moderately small fault blocks and a number of very small ones, some of which are southeast of Garrity Hill and of Big Gulch (called Lime Kiln Gulch by Mahorney), in secs. 2 and 3, T. 4 N., R. $12 \mathrm{~W}$. This part of the area is separated from Garrity Hill by morainal deposits, across which faults can be correlated only in part.

The valley of Warm Springs Creek where it skirts Garrity Hill ranges in altitude from 5,600 to nearly 5,900 feet. The highest outcrops of Permian rocks on the hill are at nearly 8,000 feet, but most of them are below 7,500 feet. As shown in cross section by both Calkins and Mahorney, most of the Permian rocks in the synclines are above 5,000 feet, but they may go considerably lower beneath the extensive cover to the east. Most of the structural relief on the Permian is less than 3,000 feet, therefore, and most of the Permian is higher than Warm Springs Creek. The rocks in this area are so much broken by faults that a considerable part of the phosphate is probably spoiled for mining. The steep dip and the thinness of the phosphate bed also make it impossible to mine much of it from the surface. Transportation of whatever can be mined is favored, however, by nearness to the railroad serving the lime quarry north of Warm Springs Creek. Most of the area is under lease or prospecting permit to the Stauffer Chemical Co.

Permian rocks are believed to underlie a considerable area near and north of Anaconda, mostly in T. $5 \mathrm{~N}$., R. 11 W. Nichelson and Pott (1948, pl. 10) showed two fault blocks in the northern part of the township in which these rocks might be present. In the western block, they mapped Lower Mississippian to Cretaceous strata but stated that Permian rocks were not observed.
In the eastern block, Cretaceous strata crop out over a large area, and Permian strata must lie at considerable depth. Wanek and Barclay $(1966$, pl. 1) showed Permian rocks at an altitude of less than 3,500 feet in this area. They showed no Paleozoic rocks as young as Permian in the western block.

South of Lost Creek, in the southern part of this township, rocks of Mississippian to Cretaceous age, dipping east, are shown on the Montana geologic map (Ross and others, 1955), and in T. 6 N. Cretaceous rocks are shown, but Wanek and Barclay showed Eocene volcanic rocks and Cretaceous sedimentary rocks in that area. On plates 30 and $34 A$, the area underlain by Permian rocks is inferred from the State map and from Wanek and Barclay, but it should be emphasized that there is much uncertainty about the distribution of Permian rocks near Anaconda. This whole area is at the west edge of the Deer Lodge Valley; the Eocene and older rocks are bordered on the east by valley-fill deposits and on the south by intrusive rocks at the east end of the Anaconda Range.

The area north of Warm Springs Creek is estimated to contain 10 million tons of furnace-grade phosphate rock but no high-grade phosphate rock (table 10). The Garrity Hill area is estimated to contain eight to nine times this amount. Geologic information for the remaining part of the Anaconda district is insufficient to warrant the estimation of phosphate resources. In the area near Anaconda, if Permian rocks are actually present and contain phosphate comparable in grade to that at lot 1337, 4 miles to the west, they would contain a considerable reserve.

\section{PHILIPSBURG DISTRICT}

In the Philipsburg district (T. 7 N., R. 13 and 14 W., and the west half of T. 8 N., R. 13 W.), Permian rocks crop out over an area 13 miles long from north to south, $21 / 2$ miles wide in the middle, and very narrow at both ends. Its northern part crosses Boulder Creek about a mile southeast of Maxville, and its south end is 2 miles south of Philipsburg. The area is west and northwest of the Philipsburg stock and immediately east of the Philipsburg thrust, which bevels off the upper Paleozoic strata south of the town. The northern part of the area is bounded on the east by the Bungalow fault, which extends north from the west edge of the Philipsburg stock and transects the Permian strata in the axial part of a tight syncline about half a mile north of Boulder Creek.

The geology of this area has been studied by Emmons and Calkins (1913), Pardee (1917, 1936), and McGill 
(1959). Field examination by the author consisted chiefly in measuring and sampling the Permian rocks at the Dissett mine (lot 1386).

The geologic structure in the central part of the Philipsburg district includes four folds. From west to east, these are the Red Hill anticline, the Wyman Gulch syncline, the Philipsburg anticline, and the Stewart Mountain syncline. All these folds plunge northward. They are tight and overturned on the west side of the area, toward the Philipsburg thrust, and progressively more open eastward. The Philipsburg anticline dies out northward, and the two synclines join within about 2 miles from the point where Permian rocks cross its axis in outcrop. The Stewart Mountain syncline is cut off on the northeast side by a large fault that extends north from the Philipsburg stock. This fault was regarded by Calkins (Emmons and Calkins, 1913), and by Pardee (1936), as the west side of a downfolded segment of the Philipsburg orerthrust. McGill (1959) called it the Bungalow fault (so named on pl. 34) and considered it a steep reverse fault, down on the east.

The fold called by Pardee ${ }^{1}$ the Wyman Gulch syncline contains Permian rocks as far south as the Dissett mine, at the south end of Red Hill and just north of Philipsburg. In its northern part this fold is bounded on the west by a steep reverse fault (Bungalow thrust of Pardee, Wyman Gulch fault of McGill); southward the fault crosses the Red Hill anticline, next to the west, and it may join the Philipsburg thrust north of Philipsburg. The syncline is very tight in the southern part, and the west limb is overturned. It plunges gently northward to its junction with the Stewart Mountain syncline. A little farther north, in sec. 29, T. 8 N., R. $13 \mathrm{~W}$., it narrows abruptly, and continues narrow for $31 / 2$ miles to the north end.

About 2 miles east of Maxville, east of the middle of T. $8 \mathrm{~N}$., R. $13 \mathrm{~W}$., is a west-dipping thrust fault of moderate stratigraphic displacement, shown as the Georgetown(?) thrust on plate $34 A$. Calkins (Calkins and Emmons, 1915) mapped this thrust as the east side of the large downfolded segment of the Philipsburg thrust, and the fault along the northeast side of the Philipsburg district as the western boundary of that segment. Pardee (1936) modified that interpretation by showing the Bungalow thrust as a steep reverse fault that displaced the downfolded Philipsburg thrust along a 3-mile interval near Boulder Creek. McGill

\footnotetext{
I McGill applied this name to the eastern syncline, here called the Stewart Mountain. Both authors may have intended to apply a single name to the pair of synclines, however, for only one name was proposed by each, but the placement of names on their maps is different.
}

(1959) showed displacement of the thrust along an 8mile interval extending south almost to the stock and past the entire east side of the northern half of the phosphate area.

As shown by both Pardee and McGill, interpreting the block east of the Bungalow as downfaulted requires that Permian rocks, which are cut off along the east side of the Stewart Mountain syncline, lie beneath part of the area of Precambrian rock between the Bungalow fault and the Georgetown(?) thrust, shown on plate $34 A$. Evidence for this interpretation does not seem conclusive, and an alternative seems worth suggesting. The Georgetown (?) thrust east of Maxville (plate $34 A$ ) can be interpreted as the northward continuation of the Georgetown thrust named by Calkins (Emmons and Calkins, 1913) and mapped by him and by Poulter (1956) south of Philipsburg. The Georgetown thrust, as mapped by them, lies below the Philipsburg thrust and ends at the south edge of the Philipsburg stock. The thrust has not been identified north of the stock, but the thrust that does extend north in the appropriate place was identified as part of the Philipsburg thrust. The interpretation proposed here infers movement on the Bungalow fault to have been up on the east, rather than down as shown by Calkins, Pardee, and McGill. This direction of movement is suggested both by the upturned beds west of the fault and by the presence of slivers of Paleozoic rocks within the fault zone. This interpretation does not negate the concept of folded thrusts in this region; such folding seems amply demonstrated. It does, however, reduce the amount of movement to be attributed to the Philipsburg thrust, it allows for continuation of the Georgetown thrust north of the Philipsburg stock, and it offers a logical interpretation of the updragged strata along the east side of Bungalow fault. It also suggests that phosphate-bearing Permian rocks do not underlie rocks of the Belt Supergroup on the east side of the Bungalow fault.

The phosphatic shales of the Retort Member were measured and sampled at only one locality in the Philipsburg area, at the Dissett mine (table 2), but Pardee's $(1917,1936)$ data from several other localities provide additional information. The sampled beds at all these localities (pl. 33) generally contain less than 31 percent $\mathrm{P}_{2} \mathrm{O}_{5}$, but at many of them 3 feet or more of beds contain more than 24 percent $\mathrm{P}_{2} \mathrm{O}_{5}$. A 3-foot layer near the New Hope shaft contains 31.9 percent and a layer 6.9 feet thick in the Dissett mine contains 25.6 percent $\mathrm{P}_{2} \mathrm{O}_{5}$. 
The general complexity of structure in the area makes it probable that many structural features too small to recognize on the surface will be found in mining. Some minor faults may offset the phosphate bed; others, about parallel to bedding, may locally eliminate or duplicate all or part of the phosphate zone or cause brecciation and dilution. Near Boulder Creek, Pardee (1936, p. 183) found breccia as much as 100 feet thick along the Bungalow fault, which is there nearly parallel to the bedding. In the Dissett mine, many small faults can be observed, and crumpling and shearing of the soft middle shaly zone of the Retort Member made measurements of thickness uncertain. In other parts of the Philipsburg area, however, the structure is less complex.

Effects probably due to prolonged weathering during middle Tertiary time are very apparent in the Dissett mine. Carbonate beds below the Retort Member have been changed to soft rocks readily penetrated by a geologic pick, the soft normally dark-colored shaly beds in the Retort Member are now light-gray to tan (Munsell value of 6 or higher), and a heavy phosphate "bloom" has been deposited on joint surfaces of the conglomerate bed at the base of that member. It is conceivable that the rocks might have been thus altered hydrothermally during the period in which the ores of the Philipsburg district were being formed, but the Dissett mine is not very near the principal area of mineralization or of intrusive activity, so this appears less likely.

The lowest point at which Permian rocks crop out in the Philipsburg district is at the intersection of Boulder Creek with the Bungalow fault, whose altitude is a little less than 5,000 feet above sea level. The outcrops near Philipsburg Valley are mostly near 5,500 feet, those on the ridge west of Wyman Gulch are higher than 6,500 feet, and those on Stewart Mountain are higher than 7,000 feet. The maximum topographic relief on the Permian rocks in this area is thus a little more than 2,000 feet; these rocks are inferred to be below 3,000 feet in altitude in the structural basin near the junction of Wyman Gulch and Stewart Mountain synclines.

A small amount of phosphate has been mined in this area, mostly at the Dissett mine and at the Washington Phosphate and Silver Co. mine south of Boulder Creek near Maxville. The most recent mining was shortly after World War II for shipment to Japan as well as for direct application to soils in this region.

\section{MAXVILLE DISTRICT}

The Maxville district (pl. $34 \mathrm{~A}$ ) includes the area underlain by Permian rocks at the north end of the Flint Creek Range. The economic potential of this district may be greater than that of any of the others described in this report. The district lies northeast of Boulder Creek and northwest of the Royal stock, and it contains about 60 miles of outcrop of Permian rocks, more than half in T. 8 N., R. 12 W. The description of the geology of this area is based primarily on the work of Emmons and Calkins (1913), Pardee (1936), McGill (1959), Gwinn (1961), Mutch (1961), Mutch and Gwinn (1960), and Mutch and McGill (1962). Field examination, chiefly of Permian strata, was conducted by the author in connection with measurement and sampling of the phosphatic beds at localities 1340 , $1387,1388,1389$, and 1399 .

The Maxville district is at the north end of the west branch of the southwest Montana synclinorium. The exposed sedimentary rocks are mostly Paleozoic in the southern part and Mesozoic in the northern part of the district. These rocks have been invaded by several large and many small bodies of plutonic and hypabyssal igneous rock of Late Cretaceous or early Tertiary age. In general, the structural uplift has been greatest near the larger plutons.

Sections were measured at six localities in this district (tables 3-8), and analyses of the phosphatic rocks were made of samples from five. Pardee (1936) reported data from several others. The data from the six localities show that the phosphate rock of minable thickness and grade (24 percent or more $\mathrm{P}_{2} \mathrm{O}_{\overline{5}}$ ) in the Maxville district (pl. 33) is confined to the upper part of the Retort Phosphatic Shale Member. However, almost every bed in the member is phosphatic, and in the northern part of the district, where the member is thinner, the averago $\mathrm{P}_{2} \mathrm{O}_{5}$ content is 24 percent at one locality and almost that much at others.

Five stratigraphic zones can be distinguished in the Retort Member. (See pl. 32.) The top and bottom zones - the upper sandy zone and the lower sandy zone of plate 32-are generally sandy, too thin, and too poor in phosphate to be of economic interest, though the top zone at the Edgar mine (lot 1389) is an exception. The middle zone, which constitutes most of the lower half of the member at some localities in this district, is very shaly. The upper phosphatic zone averages less than 5 feet in thickness and the lower one less than $1 \frac{1}{2}$ feet (table 9). 
TABLE 3.-Measured section and analyses of Retort Phosphatic Shale Member of Phosphoria Formation in Moonlight mine, Montana, lot 1340

[ Section measured and described by R. W. Swanson and sampled by R. A. Zeller, August 1950, in the Moonlight mine, south side of Princeton Gulch, NW1/4 sec. 29, T. 8 N., R. 12 W., Granite County, Mont. Locality is on west limb of west branch of Coberly syncline; beds in east drift strike N. $30^{\circ} \mathrm{W}$. and dip $42^{\circ} \mathrm{NE}$. Beds Rt-1 through Rt-3 measured In east drift at junction with crosscut about 400 feet from portal; beds Rt-4 through Rt-10 measured on south face of east drift about 500 feet from portal; beds $\mathrm{Rt-X}$ and Rt-11 through Rt-15 measured in stope above main drift, which is reached by raise about 600 feet from portal. Samples analyzed for $\mathrm{P}_{2} \mathrm{O}_{5}$ and acid insoluble
by U.S. Bur. Mines and for other constituents by U.S. Geol. Survey. LOI, loss on ignition]

$$
\text { Bed Thickness }
$$

Retort Phosphatic Shale Tongue of Phosphoria Formation, top not exposed:

Rt-15_- 0.5 Sandstone: hard, pale-brown $(5 Y R$ 5/2) fine-grained; contains abundant black phosphate pellets as much as $1 / 2 \mathrm{~mm}$ in diameter and some nodules of hard dark-gray $(N 3)$ medium-pelletal finely sandy phosphorite; contains yellow limonitic material in much of matrix; sponge spicules(?) common. Exposed at back of stope.

14._- 1.9 Phosphorite: medium-hard to soft and locally friable, dark-gray $(N 3)$, thickto very thick bedded, medium- to coarsely pelletal; contains very fine sand toward top; matrix locally pale brown to weak yellowish brown

13c.- . 1 Mudstone: soft, brownish-gray (10YR $4 / 1)$ to light-yellowish-brown (10YR $6 / 4)$, fissile to thin-bedded.

13b_- . 15 Phosphorite: muddy, soft to mediumhard, light-browish-gray $(10 Y R$ 5/1), medium-pelletal.

13a_- . 25 Mudstone and phosphorite, interlaminated: soft to medium-hard, lightgrayish-red $(5 R 5 / 2)$, thin-bedded, finely to medium-pelletal; phosphate pellets disseminated through mudstone laminae.

12_._ . 7 Phosphorite: soft and somewhat friable, dark-gray (N 3), thin-bedded, mediumpelletal; contains mudstone laminae toward top, and yellow to red iron stain in matrix.

11... . 4 Phosphorite: soft to friable, mediumdark-gray $(N 4)$, finely pelletal; grades up into soft light-yellowish-gray $(10 Y R$ $7 / 1)$ to light-yellowish-brown (10YR 6/4) clayey mudstone at top; basal contact somewhat irregular.

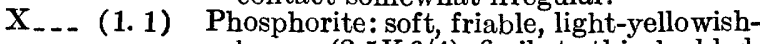
brown $(2.5 Y 6 / 4)$, fissile to thin-bedded, finely to medium-pelletal; contains $0.1-\mathrm{ft}$ soft clayey mudstone near base. Equivalent to beds Rt-9 and 10 .

10.-- 1. 4 Phosphorite: soft to medium-hard, somewhat friable, brownish-gray $(10 Y R$ 4/1), thin-bedded and laminated, finely pelletal.

9..._ . 3 Phosphorite and mudstone: soft, friable pale-brown (10YR 5/2) thin-bedded finely pelletal phosphorite grading up into soft to plastic grayish-orange (10YR 7/4) thin-bedded mudstone containing laminae of fine phosphate pellets; basal contact irregular.

$$
\text { Bed Thickness (feet) Description }
$$

Retort Phosphatic Shale Tongue of Phosphoria Formation, top not exposed-Continued

Rt-8_... 1.3 Mudstone: phosphatic, very soft to plastic, very pale brown $(10 Y R \quad 7 / 2)$ to light-brownish-gray $(10 Y R \quad 6 / 1)$, thinbedded to laminated; contains very fine to fine phosphate pellets throughout, abundant in some layers; contains red and yellow mudstone layer $0.4 \mathrm{ft}$ above base; basal contact irregular, possibly sheared.

7._._. 3 Mudstone: phosphatic, plastic, mostly moderate-orange-pink $(10 R, 7 / 4)$ to grayish-orange (10YR 7/4) but contains pale-reddish-brown $(10 R \quad 5 / 4)$ layers, thin-bedded; phosphate pellets disseminated and fine, but absent in reddish layers; basal contact gradational.

6...- 1.6 Mudstone: soft to plastic, light-brownishgray $(10 Y R$ 6/1) with some lightyellowish-brown $(10 Y R \quad 6 / 4)$ layers, thin-bedded; contains finely pelletal phosphate in some layers; basal contact gradational.

5... . 4 Mudstone: similar to Rt-6 but not phosphatic.

4...- 1. 0 Phosphorite: muddy, medium-hard to soft and plastic, brownish-gray (10YR $3 / 1)$ to moderate-yellowish-brown $(10 Y R$ 5/4) to light-brownish-gray $(10 Y R$ 6/1), fissille to thin-bedded, finely to medium-pelletal; unit more muddy and more finely pettetal upward.

3_. 8 Phosphorite: hard, brownish-gray (10YR 4/1) (pellets darker than matrix), thickbedded, finely to coarsely pelletal; contains hard dark-brownish-gray (10YR 3/1) medium-pelletal cherty (?) phosphate nodules in lower two-thirds.

2... . 6 Phosphorite: hard, pale-brown (7.5YR $5 / 2)$ to dark-brownish-gray $(10 Y R 3 / 1)$, thick-bedded, medium-pelletal; contains phosphate nodules in lower part; top 0.1 ft pale brown (10YR 5/2) and very muddy.

1... 1. 3 Sandstone: hard, yellowish-gray (10YR 7/1), one bed, fine-grained; upper half phosphatic; contains many brownishblack (10YR 2/1) sandy phosphate nodules near top; cement is carbonatic

\begin{tabular}{|c|c|c|c|c|c|c|c|c|c|c|}
\hline \multirow{2}{*}{ Bed } & \multirow{2}{*}{ Sample } & \multirow{2}{*}{$\begin{array}{l}\text { Thickness } \\
\text { (feet) }\end{array}$} & \multicolumn{6}{|c|}{ Chemical analyses (percent) } & \multicolumn{2}{|c|}{$\underset{\text { (percent) }}{\text { Uranium content }}$} \\
\hline & & & $\mathrm{P}_{2} \mathrm{O}_{5}$ & $\mathrm{Al}_{2} \mathrm{O}_{3}$ & $\mathrm{Fe}_{2} \mathrm{O}_{3}$ & LOI & $\begin{array}{c}\text { Acid } \\
\text { insoluble }\end{array}$ & $\begin{array}{c}\text { Organic } \\
\text { matter } \\
\end{array}$ & $\mathrm{eU}$ & $\mathrm{U}$ \\
\hline 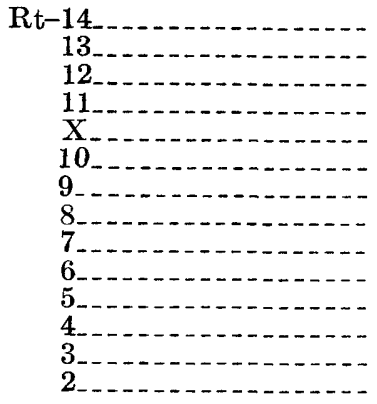 & 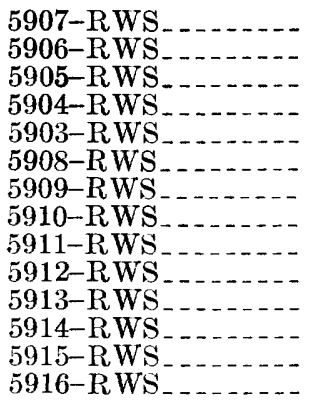 & $\begin{array}{r}1.9 \\
.5 \\
.7 \\
.4 \\
1.1 \\
1.4 \\
.3 \\
1.3 \\
.3 \\
1.6 \\
.4 \\
1.0 \\
.8 \\
.6\end{array}$ & $\begin{array}{l}\text { 35. } 4 \\
22.3 \\
37.0 \\
26.7 \\
32.8 \\
33.6 \\
26.2 \\
13.0 \\
8.4 \\
6.4 \\
1.4 \\
21.4 \\
34.2 \\
31.0\end{array}$ & $\begin{array}{l}0.78 \\
5.66 \\
1.29 \\
\text { 4. } 86 \\
3.11 \\
2.47 \\
5.54 \\
9.52 \\
\text { 10. } 3 \\
10.6 \\
11.4 \\
7.10 \\
2.39 \\
2.63\end{array}$ & $\begin{array}{l}\text { 1. } 69 \\
\text { 5. } 16 \\
\text { 1. } 25 \\
\text { 5. } 01 \\
\text { 2. } 27 \\
\text { 1. } 35 \\
\text { 2. } 25 \\
\text { 4. } 06 \\
\text { 5. } 59 \\
\text { 4. } 03 \\
\text { 5. } 83 \\
\text { 4. } 39 \\
\text { 1. } 38 \\
\text { 1. } 58\end{array}$ & $\begin{array}{l}1.17 \\
2.68 \\
1.22 \\
2.85 \\
2.29 \\
1.67 \\
3.56 \\
4.51 \\
5.11 \\
3.52 \\
4.47 \\
3.95 \\
1.97 \\
2.19\end{array}$ & $\begin{array}{r}7.7 \\
28.5 \\
3.8 \\
18.2 \\
10.4 \\
9.8 \\
21.8 \\
49.4 \\
57.3 \\
66.2 \\
79.7 \\
29.7 \\
7.7 \\
13.0\end{array}$ & $\begin{array}{r}0.68 \\
.97 \\
.50 \\
1.06 \\
.69 \\
.62 \\
1.44 \\
1.60 \\
1.95 \\
.85 \\
1.25 \\
1.29 \\
1.01 \\
.59\end{array}$ & $\begin{array}{r}0.005 \\
.003 \\
.003 \\
.003 \\
.005 \\
.004 \\
.004 \\
.005 \\
.004 \\
.004 \\
.004 \\
.005 \\
.003 \\
.005\end{array}$ & $\begin{array}{r}0.006 \\
.004 \\
.004 \\
.003 \\
.004 \\
.005 \\
.004 \\
.005 \\
.004 \\
.003 \\
.002 \\
.007 \\
.004 \\
.005\end{array}$ \\
\hline
\end{tabular}
in places, siliceous elsewhere. 
TABLE 4.-Measured section of Permian rocks near Little Gold Creek, south of Moonlight mine, Montana, lot 1340a

[Section measured and described by R. W. Swanson and R. A. Zeller, August 1950, in hand trench and outcrop nearly three-fourths of a mile southeast of Moonlight mine (lot 1340) on north side of little Gold Creek, SW1/4 sec. $29, \mathrm{~T} .8 \mathrm{~N} ., \mathrm{R} .12 \mathrm{~W}$., Granite County, Mont. Locality is on west limb of west branch of Coberly syncline about 1 mile west of Royal stock, and strata are metamorphosed; beds strike N.' $40^{\circ}$ W. and dip $25^{\circ}$ NE. Retort Member not well exposed]

$$
\text { Bed Thickness }
$$

Description

Tosi Chert Tongue of Phosphoria Formation, basal bed:

To-28_. 3.0 Chert: hard, light-brownish-gray (10YR $6 / 1)$, poorly bedded. In oil, found to contain quartz grains, carbonate, apatite, and spinel or garnet? (high index, isotropic). Apatite looks like igneous variety and is clearly recrystallized. Hand specimen has appearance of finegrained quartzite.

Retort Phosphatic Shale Tongue of Phosphoria Formation:

Rt-27_- 1.0 Hornfels: hard, light-brownish-gray $(10 Y R$ 6/1), laminated; contains some carbonate; scratches readily with needle; originally mudstone.

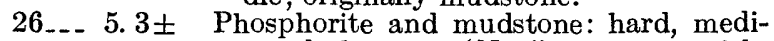
um-dark-gray $(N \quad 4)$ to brownishgray $(10 Y R 4 / 1)$, thin-bedded; some phosphate pellets recognizable, but most of material is microcrystalline and unidentifiable; beds sheared and not well enough exposed to accurately determine stratigraphic sequence and thickness.

25_._ . 7 Phosphorite: hard, moderate-yellowishbrown (10YR 6/4), medium- to coarsely pelletal and oolitic; pellets dark-gray, oolite centers commonly yellowishgray, matrix light-yellowish-brown to dark-yellowish-orange; one bed; probably equivalent to bed $\mathrm{Rt}-3$ in Moonlight mine.

24_-_. 4 Mudstone: hard, light-brownish-gray $(10 Y R 5 / 1)$, one bed.

23._. 6 Phosphorite: hard, medium-dark-gray $(N 4)$, one bed, medium-pelletal and oolitic; iron-stained in part; contains quartz grains toward base; basal contact gradational.

Lower tongue of Shedhorn Sandstone:

LS-22_. 2.4 Sandstone: hard, medium-dark-gray ( $N$ 4) to light-brownish-gray $(10 Y R$ 6/1), poorly bedded, fine-grained; contains considerable phosphate at top and tremolite near top; cement calcareous to siliceous; basal contact somewhat irregular.

Park City Formation:

PC-21__13. $0 \pm$ Marble: hard, light-gray $(N 7)$ to yellowish-white $(10 Y R$ 9/1), poorly bedded, finely to coarsely crystalline; contains much tremolite, irregularly' distributed; locally cherty; weathers to very irregular surface.

20..- 4. 0 Carbonate rock: cherty, hard. light-gray $(N 7)$ with medium-dark-gray ( $N$ 4) chert, poorly bedded, aphanitic; contains some coarsely crystalline quartz. 19.- 1. 2 Covered.

18.- 1. 9 Marble: cherty, hard, light-brownish-gray $(10 Y R 6 / 1)$ to pale-orange $(10 Y R$ 8/2), aphanitic to medium-crystalline; contains much tremolite in some layers and many small pyrite cubes.

17..- 5. 3 Marble: tremolitic, hard, yellowish-white (10YR 9/1), finely crystalline; contains some small recrystallized (finely sugary) chert concretions.

16 Covered.

15._. 2. 3 Marble: cherty, hard, very pale orange $(10 Y R$ 9/2) with light-gray $(N 7)$ chert; chert recrystallized; contains much tremolite.

14.-_ . 9 Marble: hard, medium-light-gray ( $N$ 6); medium-crystalline; contains much tremolite. $\begin{array}{ccc}\text { Bed } & \begin{array}{c}\text { (feet) } \\ \text { Park City Formation-Continued }\end{array} \text { Description } & \\ \text { PC-13..- 2.1 } & \text { Marble: hard, white }(N \text { 9), aphanitic; }\end{array}$

PC-13... 2. 1 Marble: hard, white $(N)$

12_-- 9. 1 Marble and chert: medium-hard pinkishgray $(5 R$ 8/1) thick-bedded finely cyrstalline talcose marble containing beds ( 0.2 to $0.4 \mathrm{ft}$ ) of medium-lightgray recrystallized chert; calcite and quartz occur as coarsely crystalline veinlets; talc occurs as abundant coarse flakes disseminated through marble; veinlets of very coarsely crystalline calcite, quartz, and talc cross chert; tremolite needles and pyrite cubes occur in 0.8 -ft platy bed of medium-hard medium-dark-gray aphanitic marble $0.9 \mathrm{ft}$ from top of unit.

11.. 3.0 Marble and chert: hard grayish-pink $(5 R 8 / 2)$ to yellowish-gray $(10 Y R 8 / 1)$ thin-bedded aphanitic to coarsely crystalline marble; contains much tremolite and prominent light-brownish-gray $(10 Y R$ 6/1) chert layers at middle and in lower half.

10-- 1.8 Chert or quartzite: hard, yellowish-gray (10YR 7/1), aphanitic to mediumcrystalline quartz; one bed.

9... 2. 0 Marble: hard, pinkish-gray (5YR 8/1), thin- to thick-bedded, very finely crystalline; contains disseminated tremolite needles and talc flakes; contains recrystallized chert nodules in layers $0.2,0.6$, and $1.6 \mathrm{ft}$ above base; basal contact irregular.

8.-19.8 Marble: cherty, hard, white $(N 9)$ to pinkish-gray ' $(5 Y R 8 / 1)$, thick-bedded to massive, contains tremolite and tale and many small to large light-gray $(N 7)$ finely recrystallized chert nodules; basal contact irregular.

7... 1.3 Marble: cherty, hard, pinkish-gray (5YR 8/1), finely crystalline; one bed; contains much tremolite and many small medium-light-gray $(N 6)$ chert nodules; basal contact irregular.

6.... 3. 7 Chert or quartzite: hard, medium-gray $\left(\begin{array}{ll}N & 5\end{array}\right)$ thick-bedded to massive aphanitic to medium-crystalline; contains tremolite or wollastonite and various iron and copper sulfides.

5.._ 5. 3 Marble: medium-hard, pinkish-white $(5 R$ 9/1), thick-bedded to massive, aphanitic; contains much acicular tremolite; contains light-gray ( $N$ 7) aphanitic chert nodules in upper half.

4... . 2 Quartzite: hard, pale-brown $(10 Y R$ 6/2), very fine grained.

3... 1. 0 Marble: medium-hard, yellowish-white $(10 Y R$ 9/1), thin-bedded, aphanitic; contains tremolite; contains thin layers of very light gray ( $N 8)$ fine-grained quartzitic sandstone near middle.

2.-3.8 Marble: medium-hard, pinkish-white (5YR 9/1), thin-bedded, finely crystalline; contains abundant coarsely crystalline tremolite; basal contact irregular.

(. 7) Beneath bed F-2 is $0.7 \mathrm{ft}$ of soft sandstone, conglomerate, and silt that is believed to be due to glaciation so is not Permian.

Quadrant Quartzite, top bed:

Q-1_..-10.0 \pm Quartzite: hard, yellowish-gray (10YR 8/1), thin-bedded at top, massive below, fine-grained. 
TABLE 5.-Measured section and analyses of Permian rocks on west limb of Douglas Mountain anticline near Gird Creek, Montana, lot 1387

[Section measured and described by R. W. Swanson, September 1953, on west limb of Douglas Mountain anticline in sec. 7, T. 8 N., R. 12 W., Granite County, Mont. Bed strike N. $10^{\circ} \mathrm{W}$. and dip $85^{\circ} \mathrm{W}$. Beds $\mathrm{Rt}-6$ through $\mathrm{Rt}-16$ measured in hand trench about 1,000 feet north of Gird Creek; beds Q-1 through PC-5 and US-17 through US-25 are poorly exposed strata east and west of adit on north side of Gird Creek. Samples analyzed for $\mathrm{P}_{2} \mathrm{O}_{5}$ and acid insoluble by U.S. Bur. Mines and for other constituents by U.S. Geol. Survey. LOI, loss on ignition]

Bed Thickness

Jurassic rocks, undifferentiated:

J-27_.. 72.5 Quartzite: hard, vitreous, light-brownishgray $(10 Y R 6 / 1)$ to pale-brown (10YR $5 / 2)$, thick-bedded to massive, fineto medium-grained; contains many small and large limonite spots, some in fossil molds (?); contains poorly preserved fossils identified as Jurassic belemnites and Pentacrinus stems (R. W. Imlay, written commun., 1959). J?-26_._ 43.9 Covered

Upper tongue of Shedhorn Sandstone:

US-25_- 2. 0 Sandstone: mostly hard, locally soft, brownish-gray (10YR 4/1), fine-grained; shattered and poorly exposed.

24_.- . 5 Sandstone: soft, brownish-gray, finegrained.

23... 9.5 Sandstone: hard, quartzitic, lightbrownish-gray, massive, fine- to medium-grained.

22..- 1. 4 Sandstone: soft to medium-hard, finegrained; quartzitic in uppermost $0.2 \mathrm{ft}$; poorly exposed.

US?-21_. . 5 Mudstone: soft, tan, thin-bedded

$20 \ldots$ Covered.

19... 1.5 Mudstone: medium-hard, pale-brown; brecciated and not certain if in place.

18_-2.0 Mudstone: soft, tan, thin-bedded.

US-17.. 9.6 Sandstone: hard, quartzitic, lightbrownish-gray, thick-bedded, fine- to medium-grained.

16._. . 9 Quartzite: cherty, hard, light-brownishgray $(10 Y R 5 / 1)$, fine- to mediumgrained; one bed; basal contact irregular.

Retort Phosphatic Shale Tongue of Phosphoria Formation:

Rt-15... . 1 Sandstone: phosphatic, soft to friable, light-yellowish-brown $(10 Y R 6 / 4)$, finegrained; phosphate medium-pelletal; basal contact irregular.

14_._ . 9 Phosphorite: hard, dark-gray (

13_._ . 75 Phosphorite: soft, light-yellowish-brown $(10 Y R 6 / 4)$ to dark-gray $(N 4)$, thin bedded, finely pelletal; upper part muddy.

\section{Bed Thickness}

Retort Phosphatic Shale Tongue of Phosphoria Formation-Con. Rt-12_.- 1. 4 Phosphorite: hard, dark-gray $\left(\begin{array}{ll}N & 4\end{array}\right)$ thin-bedded, medium-pelletal.

11._- 1.2 Phosphorite: muddy, soft, weakyellowish-orange $(2.5 Y \quad 7 / 4)$, thinbedded, medium-pelletal; basal contact gradational.

10_._ 1.8 Mudstone: phosphatic, soft, lightyellowish-brown $(2.5 Y$ 6/4), thinbedded; phosphate occurs in thin finely pelletal layers; basal contact gradational.

9._. 1. 35 Phosphorite and mudstone, interbedded: soft to friable, light-yellowish-brown $(2.5 Y 6 / 4)$, fissile to thin-bedded, finely pelletal.

8... . 45 Phosphorite: hard, medium-dark-gray ( $N$ 4), one bed, finely to medium-pelletal; contains phosphate nodules.

7b_-_. 35 Mudstone and phosphorite, interlaminated: soft, weak-yellowish-orange $(2.5 Y$ 7/4), finely pelletal; contains hard phosphate nodules near middle.

7a___ . 55 Phosphorite: soft, dark-gray $(N 3)$ to very pale brown (10YR 7/2), fissile to thinbedded, medium-pelletal; contains hard phosphate nodules near base.

6b_._. 1 Phosphorite: sandy, hard, medium-darkgray ( $N$ 4), medium-pelletal; basal contact gradational.

6a_.- 1. 4 Sandstone: phosphatic (?), hard, darkgray $(N 3)$, medium-grained; basal contact not well exposed.

Park City Formation:

PC-5_.. 6. 0 Carbonate rock: cherty, hard, gray.

4... 3.2 Chert and quartzite: hard, poorly exposed.

3... 2.3 Carbonate rock: cherty, hard; poorly exposed.

PC?-2_- 42. 0 Covered.

Quadrant Quartzite, upper part:

Q-1.... 100土 Quartzite: forms prominent ridge.

\begin{tabular}{|c|c|c|c|c|c|c|c|c|c|c|}
\hline \multirow[b]{2}{*}{ Bed } & \multirow[b]{2}{*}{ Sample } & \multirow[b]{2}{*}{$\underset{\text { (feet) }}{\text { Thickness }}$} & \multicolumn{6}{|c|}{ Chemical analyses (percent) } & \multicolumn{2}{|c|}{$\underset{\text { (percent) }}{\text { Uranium content }}$} \\
\hline & & & $\mathrm{P}_{2} \mathrm{O}_{5}$ & $\mathrm{Al}_{2} \mathrm{O}_{3}$ & $\mathrm{Fe}_{2} \mathrm{O}_{3}$ & LOI & $\begin{array}{l}\text { Acid } \\
\text { insoluble }\end{array}$ & $\begin{array}{l}\text { Organic } \\
\text { matter }\end{array}$ & $\mathrm{eU}$ & $\mathrm{U}$ \\
\hline 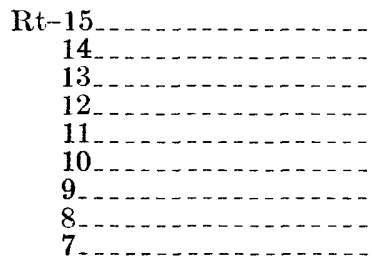 & $\begin{array}{l}\text { 5935-RWS } \\
\text { 5934-RWS } \\
\text { 5933-RWS } \\
\text { 5932-RWS } \\
\text { 5931-RWS } \\
\text { 5930-RWS } \\
\text { 5929-RWS } \\
\text { 5928-RWS } \\
\text { 5927-RWS }\end{array}$ & $\begin{array}{l}0.1 \\
.9 \\
.75 \\
1.4 \\
1.2 \\
1.8 \\
1.35 \\
.45 \\
.9\end{array}$ & $\begin{aligned} \text { 10. } 6 \\
29.6 \\
26.8 \\
34.0 \\
18.6 \\
9.1 \\
16.5 \\
28.4 \\
23.8\end{aligned}$ & $\begin{array}{r}\text { 2. } 7 \\
1.3 \\
\text { 5. } 8 \\
\text { 2. } 2 \\
8.7 \\
\text { 11. } 5 \\
9.0 \\
\text { 2. } 0 \\
\text { 5. } 4\end{array}$ & $\begin{array}{l}\text { 3. } 56 \\
.88 \\
\text { 3. } 88 \\
.96 \\
\text { 1. } 78 \\
\text { 2. } 44 \\
\text { 1. } 92 \\
\text { 1. } 32 \\
\text { 2. } 14\end{array}$ & $\begin{array}{l}\text { 1. } 86 \\
\text { 1. } 40 \\
\text { 3. } 50 \\
\text { 2. } 10 \\
\text { 3. } 76 \\
\text { 3. } 96 \\
\text { 3. } 88 \\
\text { 2. } 20 \\
\text { 2. } 90\end{array}$ & $\begin{array}{r}66.7 \\
9.4 \\
16.8 \\
9.3 \\
37.8 \\
55.0 \\
41.6 \\
10.3 \\
28.5\end{array}$ & $\begin{array}{l}0.61 \\
.19 \\
.85 \\
.25 \\
.97 \\
.91 \\
.51 \\
.39 \\
.49\end{array}$ & $\begin{array}{l}0.003 \\
.010 \\
.008 \\
.010 \\
.009 \\
.007 \\
.007 \\
.008 \\
.007\end{array}$ & $\begin{array}{r}0.002 \\
.009 \\
.008 \\
.010 \\
.008 \\
.005 \\
.005 \\
.007 \\
.006\end{array}$ \\
\hline
\end{tabular}


TABLE 6.-Measured section and analyses of Retort Phosphatic Shale Member of Phosphoria Formation in Douglas Creek No. 3 North mine, Montana, lot 1388

[Section measured and described by R. W. Swanson, September 1953, at end of adit level about 1,650 feet north of portal in Douglas Creek No. $3 \mathrm{North}$ mine, sec. 31, T. $9 \mathrm{~N}$., $\mathrm{R} .12 \mathrm{~W}$., Granite County, Mont. Locality is on east limb of Douglas Mountain anticline; beds strike $\mathrm{N}$. $5^{\circ} \mathrm{W}$. and dip about $50^{\circ} \mathrm{E}$. Samples analyzed for $\mathrm{P}_{2} \mathrm{O}_{5}$ and acid
insolubble by U.S. Bur. Mines and for other constituents by U.S. Geol. Survey. Sources for additional analyses of samples 5944 and 5946 are cited by Gulbrandsen (1966). LOI, loss on ignition]

$$
\text { Bed Thickness } \quad \text { Deet) }
$$

Retort Phosphatic Shale Tongue of Phosphoria Formation:

Rt-20__- 1. 4 Quartzite: cherty, hard, light-brownishgray $(10 Y R 5 / 1)$, one bed, fine-grained; contains phosphate pellets and oolites; basal contact irregular.

19... . 8 Phosphorite: hard, medium-dark-gray $(N 4)$, thick-bedded, medium- to coarsely pelletal and oolitic; contains phosphate nodules; uppermost part sandy, more nodular, and contains some pebbles of phosphatic sandstone; a persistent shale parting is $0.2 \mathrm{ft}$ above base; basal contact sheared.

18_._ . 5 Phosphorite:medium-hard, medium-darkgray (N4), medium-pelletal; contains considerable carbonate as matrix and in fractures; basal contact irregular.

17... . 3 Phosphorite: muddy, soft to mediumhard, dark-gray (N3) to light-olivebrown $(2.5 Y 5 / 4)$, thin-bedded, mediumpelletal; top $0.05 \mathrm{ft}$ sheared and gougy; lower half contains mudstone laminae; basal contact irregular.

16... .5 Phosphorite: medium-hard, mediumlight-gray (dark-gray pellets in lightgray matrix), fissile to thick-bedded, medium-pelletal; basal contact irregular.

15... . 4 Limestone: cherty, soft to hard, lightyellowish-brown $(10 Y R$ 6/4), thinbedded, aphanitic; gougy and sheared, locally vuggy; basal contact somewhat irregular, locally a shear plane.

14.-- 1. 45 Phosphorite: soft to medium-hard, medium-dark-gray ( $N 4$ ), fissle to thinbedded, medium pelletal.

13.-. . 7 Phosphorite: muddy, medium-hard, medium-dark-gray $(N 4)$, finely pelletal; contains $0.1-\mathrm{ft}$ medium-hard pale-brown (10YR 5/3) mudstone just below middle.

12... .45 Mudstone: medium-hard, brownish-gray $(10 Y R 4 / 1)$ to grayish-brown (10YR $4 / 2)$, laminated to thin-bedded; contains pelletal phosphate in laminae at top and bottom; basal contact gradational.

11... . 7 Mudstone: phosphatic, medium-hard, dark-gray $(N 3)$, thin-bedded, finely to medium-pelletal; basal contact gradational.

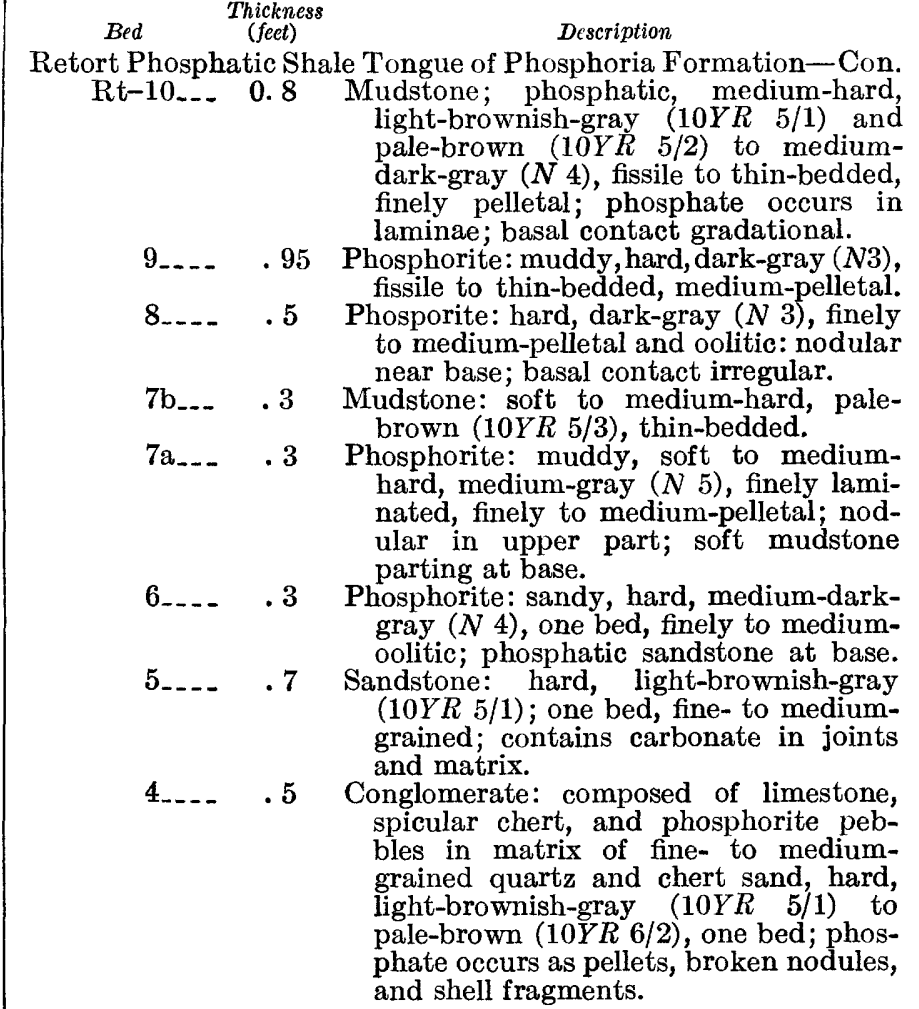

Park City Formation, upper part:

PC-3...- . 9 Carbonate rock: hard, light-brownish; gray $(10 Y R 5 / 1)$, one bed, aphaniticcontains numerous quartz and chert grains, some phosphate pellets, and a few pebbles of fine-grained sandstone; basal contact irregular.

2... . 6 Conglomerate: hard; composed of lightyellowish-brown $(10 Y R$ 6/4) carbonate and pale-brown $(10 Y R$ 5/2) chert pebbles in light-yellowish-brown aphanitic carbonate matrix; one bed; chert contains spicules, quartz grains, and dolomite rhombs; basal contact irregular.

1... . . Limestone: hard, pale-brown $(10 Y R 5 / 2)$, aphanitic; lowest bed exposed in drift. 
TABLE 7.-Measured section and analyses of Retort Phosphatic Shale Member of Phosphoria Formation in east adit of Edgar mine, Montana, lot 1389-Continued

Retort Phosphatic Shale Tongue of Phosphoria Formation-Con. | Retort Phosphatic Shale Tongue of Phosphoria Formation-Con.

$$
\text { Bed Thickness }
$$

Rt-3b... $\quad 0.6$

$$
3 a_{-} .5 \text {. } 5 \text { h }
$$

\section{Description}

Mudstone: medium-hard, light-yellowishbrown (10YR 6/4), thin-bedded.

Phosphorite and mudstone, interbedded: soft to medium-hard medium-gray $\left(\begin{array}{ll}N & 5\end{array}\right)$ fissile to thin-bedded finely pelletal to nodular phosphorite and soft light-yellowish-brown (10YR 6/4) mudstone; basal contact irregular.

\section{Bed Thickness Description}

Rt-2

Conglomerate: phosphatic, hard, one bed; pebbles of brownish-gray $(10 Y R 4 / 1)$ spicular chert as much as $0.1 \mathrm{ft}$ long in phosphatic, quartzitic fine- to mediumgrained sand matrix with limestone pebbles at base and nodular mediumpelletal sandy phosphorite in top 0.05 ft; exposed in pit dug in adit floor. 1... . 1 Conglomerate: pebbles of spicular chert,

\begin{tabular}{|c|c|c|c|c|c|c|c|c|}
\hline \multirow{2}{*}{ Bed } & \multirow{2}{*}{$\underset{\text { (feet) }}{\text { Thickness }}$} & \multicolumn{5}{|c|}{ Chemical analyses (percent) } & \multicolumn{2}{|c|}{ Uranium content } \\
\hline & & $\mathrm{P}_{2} \mathrm{O}_{5}$ & $\mathrm{Al}_{2} \mathrm{O}_{3}$ & $\mathrm{Fe}_{2} \mathrm{O}_{3}$ & LOI & $\begin{array}{c}\text { Acid } \\
\text { insoluble }\end{array}$ & $\mathrm{eU}$ & $\mathrm{U}$ \\
\hline $\begin{array}{r}\text { Rt-12 } \\
11 \ldots \ldots \\
10 \ldots \ldots \\
9 \\
8 \ldots \ldots\end{array}$ & $\begin{array}{r}0.5 \\
2.9 \\
2.1 \\
\text { 1. } 3 \\
.7 \\
\text { 1. } 7 \\
\text { 1. } 4 \\
\text { 1. } 6 \\
.6\end{array}$ & $\begin{array}{l}\text { 24. } 1 \\
\text { 24. } 5 \\
\text { 36. } 2 \\
\text { 30. } 1 \\
\text { 32. } 5 \\
\text { 19. } 2 \\
\text { 11. } 0 \\
\text { 15. } 7 \\
\text { 29. } 7 \\
\text { 13. } 1 \\
\text { 14. } 0\end{array}$ & $\begin{array}{r}1.8 \\
1.2 \\
1.1 \\
4.5 \\
2.2 \\
8.4 \\
10.2 \\
9.1 \\
2.5 \\
7.9\end{array}$ & $\begin{array}{l}\text { 2. } 72 \\
\text { 1. } 02 \\
.56 \\
\text { 1. } 88 \\
\text { 1. } 48 \\
\text { 2. } 58 \\
\text { 3. } 76 \\
\text { 3. } 82 \\
\text { 1. } 00 \\
\text { 3. } 58\end{array}$ & $\begin{array}{l}1.92 \\
2.28 \\
2.50 \\
3.50 \\
2.82 \\
4.48 \\
4.80 \\
5.00 \\
3.32 \\
4.12 \\
-\end{array}$ & $\begin{array}{r}33.3 \\
34.2 \\
5.0 \\
16.4 \\
12.2 \\
35.4 \\
54.2 \\
41.3 \\
17.6 \\
50.5 \\
61.3\end{array}$ & $\begin{array}{r}0.006 \\
.007 \\
.012 \\
.010 \\
.012 \\
.010 \\
.006 \\
.007 \\
.007 \\
.006 \\
.005\end{array}$ & $\begin{array}{l}0.006 \\
.007 \\
.011 \\
.009 \\
.011 \\
.010 \\
.005 \\
.006 \\
.007 \\
.004 \\
.005\end{array}$ \\
\hline
\end{tabular}
limestone, and sandstone; top of bed.

1 Other constituents:

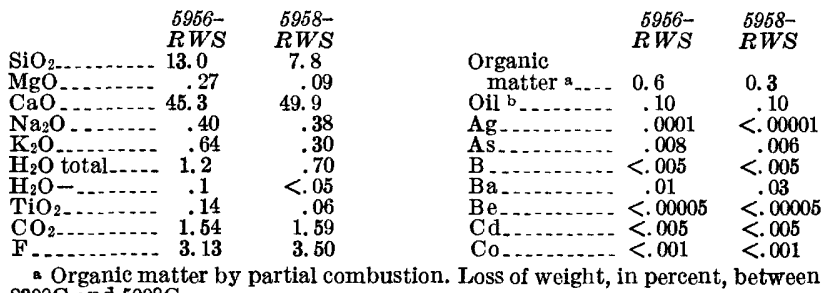

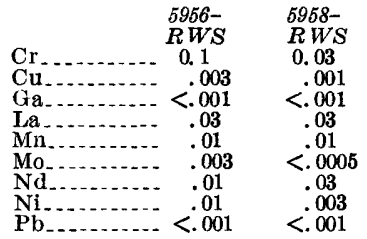

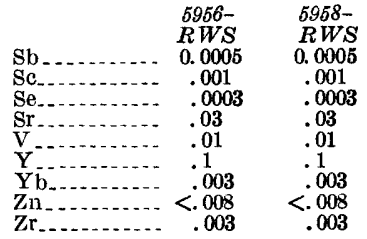
$230^{\circ} \mathrm{C}$ and $500^{\circ} \mathrm{C}$

TABLE 8.-Measured section and analyses of Permian rocks on east limb of Douglas Mountain anticline near Gird Creek, Montana, lot 1399

[Section measured by R.W. Swanson, July 1954, in Montana Phosphate Products Co. bulldozer trench about 1,500 feet north of Gird Creek in NE14 sec. 7, T. 8 N., R. 12 W. Granite County, Mont. Beds strike north and dip $63^{\circ} \mathrm{E}$. Samples analyzed for $\mathrm{P}_{2} \mathrm{O}_{5}$ and acid insoluble by U.S. Bur. Mines and for uranium by U.S. Geol. Survey]

$$
\begin{gathered}
\text { Thickness } \\
\text { Beet) }
\end{gathered} \quad \text { Description }
$$

Tosi Chert Tongue of Phosphoria Formation, basal bed:

To-13_._ 5. 3 Chert: sandy, hard, light-gray $(N 7)$ to light-brownish-gray $(10 Y R$ 6/1), very thick bedded; grades from bed below through $0.2 \mathrm{ft}$ of grayish-brown (10YR $4 / 2$ ) fine- to medium-grained cherty quartzite.

Retort Phosphatic Shale Tongue of Phosphoria Formation: Rt-12b_- . 25 Quartzite: hard, light-brownish-gray (10YR 5/1), fine- to medium-grained; basal contact gradational.

12a_- . 35 Phosphorite: hard, medium-dark-gray irregular and gradational.

11... . 85 Phosphorite: hard, medium-dark-gray $(N 4)$ to light-brownish-gray $(10 Y R$ $5 / 1$ ), thin- to thick-bedded, mediumto coarsely pelletal.

10_._ . 85 Phosphorite: interbedded hard mediumdark-gray $(N$ 4) to pale-brown $(10 Y R$ $6 / 2$ ) thin- to thick-bedded mediumpelletal phosphorite and soft lightyellowish-brown $(10 Y R$ 6/4) to very pale brown $(10 Y R \quad 7 / 3)$ thin-bedded muddy phosphorite; basal $0.15 \mathrm{ft}$ gougy.

9.-_ 1. 25 Phosphorite: medium-hard to hard, medium-dark-gray $\left(\begin{array}{l}N \\ 4\end{array}\right)$, thin-bedded, medium-pelletal.

8..- .6 Mudstone: phosphatic, medium-hard, pale-brown $(10 Y R 5 / 2)$, fissile to thinbedded; phosphate occurs in very finely to medium-pelletal thin beds and laminae. $\begin{array}{cc}\text { Bed } & \text { Thickness } \\ \text { (feet) } & \text { Description } \\ \text { Retort Phosphatic Shale Tongue of Phosphoria }\end{array}$

Thosphoria Formation-Con. hard, grayish-brown $(10 Y R 4 / 2)$ and light-yellowish-brown $(10 Y R \quad 6 / 4)$ to moderate-yellowish-brown $(10 Y R 5 / 6)$, fissile to thin-bedded; phosphate occurs in very finely to finely pelletal laminae.

6..- . 4 Mudstone: phosphatic, very soft to medium-hard, light-brownish-gray (10YR $5 / 1)$ to light-yellowish-brown (10YR 6/4), fissile to thin-bedded; phosphate is very finely to finely pelletal.

5... . 7 Mudstone: phosphatic, medium-hard, pale-brown $(10 Y R 5 / 3)$; thin- to thickbedded phosphate occurs in very finely pelletal laminae.

4..._ .5 Phosphorite: muddy, soft to hard, palebrown $(10 Y R 5 / 3)$, fissile to thinbedded, finely to medium-pelletal.

3... . .95 Phosphorite: muddy, soft to hard, medium-dark-gray $(N$ 4) to pale-brown $(10 Y R 5 / 3)$, fissile to thick-bedded, medium-pelletal.

2b_.. . 3 Phosphorite: hard, medium-dark-gray $(N$ 4), thin-bedded, medium pelletal.

2a... . 2 Sandstone: phosphatic, hard, brownishgray (10YR 4/1), fine-grained; basal contact irregular and gradational.

Lower tongue of Shedhorn Sandstone, top bed:

LS-1 _... 2. 0 Sandstone: hard, pale-brown (10YR 6/2) to medium-dark-gray $(N 4)$, one bed, fine-grained; top $0.1 \mathrm{ft}$ phosphatic. 
TABLE 8.-Measured section and analyses of Permian rocks on east limb of Douglas Mountain anticline near Gird Creek, Montana, lot 1399-Continued

\begin{tabular}{|c|c|c|c|c|c|c|}
\hline \multirow[b]{2}{*}{ Bed } & \multirow[b]{2}{*}{ Sample } & \multirow[b]{2}{*}{$\begin{array}{c}\text { Thickness } \\
\text { (feet) }\end{array}$} & \multicolumn{2}{|c|}{ Chemical analyses (percent) } & \multicolumn{2}{|c|}{ Uranium content (percent) } \\
\hline & & & $\mathrm{P}_{2} \mathrm{O}_{5}$ & Acid-insoluble & $\mathrm{eU}$ & $\mathrm{U}$ \\
\hline
\end{tabular}

TABLE 9.-Average chemical composition of zones in Retort Phosphatic Shale Member of Phosphoria Formation in the Maxville district and in combined Anaconda, Philipsburg, and Maxville districts, Montana

[Weighted for thickness of sampled beds]

\begin{tabular}{|c|c|c|c|c|c|c|c|c|}
\hline Zone & Thickness & $\mathrm{P}_{2} \mathrm{O}_{5}$ & $\mathrm{Al}_{2} \mathrm{O}_{3}$ & $\mathrm{Fe}_{2} \mathrm{O}_{3}$ & $\begin{array}{l}\text { Loss on } \\
\text { ignition }\end{array}$ & $\underset{\text { insoluble }}{\text { Acid }}$ & $\begin{array}{c}\text { Organic } \\
\text { matter }\end{array}$ & $\begin{array}{l}\text { Apatite } 1 \\
\text { plus acid } \\
\text { insoluble }\end{array}$ \\
\hline \multicolumn{9}{|c|}{ A. Maxville district } \\
\hline $\begin{array}{l}\text { Upper sandy }{ }^{2} \\
\text { Upper phosphatic } \\
\text { Middle shaly } \\
\text { Lower phosphatic } \\
\text { Lower sandy } 2\end{array}$ & $\begin{array}{l}\text { 1. } 4 \\
\text { 3. } 8 \\
\text { 3. } 9 \\
\text { 1. } 4 \\
.6\end{array}$ & $\begin{array}{l}\text { 18. } 4 \\
\text { 32. } 1 \\
\text { 13. } 6 \\
\text { 25. } 8 \\
\text { 14. } 0\end{array}$ & $\begin{array}{l}\text { 2. } 00 \\
\text { 2. } 50 \\
\text { 8. } 81 \\
\text { 4. } 36\end{array}$ & $\begin{array}{l}\text { 2. } 42 \\
\text { 1. } 76 \\
\text { 3. } 05 \\
\text { 2. } 06\end{array}$ & $\begin{array}{l}2.04 \\
2.98 \\
4.18 \\
\text { 2. } 98 \\
\end{array}$ & $\begin{array}{l}\text { 49. } 1 \\
11.2 \\
48.3 \\
\text { 25. } 2 \\
61.3\end{array}$ & $\begin{array}{r}0.61 \\
.53 \\
.97 \\
.74 \\
\end{array}$ & $\begin{array}{l}\text { 96. } 2 \\
93.4 \\
83.0 \\
91.3 \\
97.1\end{array}$ \\
\hline Average or total & 11. 1 & 20. 8 & 4. 42 & 2. 32 & 3. 04 & 39.0 & .71 & 92.2 \\
\hline \multicolumn{9}{|c|}{ B. Average for three districts } \\
\hline $\begin{array}{l}\text { Upper sandy }{ }^{2} \\
\text { Upper phosphatic } \\
\text { Middle shaly }{ }^{2} \\
\text { Lower phosphatic }{ }^{2} \\
\text { Lower sandy }{ }^{2}\end{array}$ & $\begin{array}{l}\text { 1. } 4 \\
\text { 4. } 6 \\
\text { 3. } 8 \\
\text { 1. } 4 \\
.6\end{array}$ & $\begin{array}{l}\text { 16. } 1 \\
30.4 \\
\text { 13. } 3 \\
26.1 \\
\text { 14. } 0\end{array}$ & $\begin{array}{l}3.16 \\
2.99 \\
9.18 \\
4.36\end{array}$ & $\begin{array}{l}\text { 2. } 34 \\
\text { 1. } 86 \\
\text { 3. } 63 \\
\text { 2. } 06\end{array}$ & $\begin{array}{l}\text { 1. } 97 \\
\text { 3. } 81 \\
\text { 7. } 29 \\
\text { 2. } 98\end{array}$ & $\begin{array}{l}52.8 \\
14.4 \\
46.5 \\
25.1 \\
61.3\end{array}$ & $\begin{array}{r}0.46 \\
.62 \\
\text { 1. } 55 \\
.74 \\
-.--\end{array}$ & $\begin{array}{l}\text { 94. } 0 \\
92.2 \\
\text { 80. } 4 \\
91.9 \\
97.1\end{array}$ \\
\hline Average or total & 11. 8 & 20.0 & 4. 92 & 2. 47 & 4. 01 & 40. 0 & .84 & 91.1 \\
\hline
\end{tabular}

1 Apatite $=\mathrm{P}_{2} \mathrm{O}_{5} \times 2.56 . \quad 2$ Information incomplete; data based on information available.

The upper phosphatic zone contains several distinct beds of high-grade phosphorite, separated by thin beds or partings of shale; although most of the shaly material is more than half phosphate, it lowers the overall percentage of $\mathrm{P}_{2} \mathrm{O}_{5}$ to about 30 (table 9 ). In addition to phosphate, the shaly beds consists chiefly of acidinsoluble material, which is dominantly quartz, plus about $41 / 2$ percent of combined $\mathrm{Al}_{2} \mathrm{O}_{3}$ and $\mathrm{Fe}_{2} \mathrm{O}_{3}$ in a ratio of about 3 to 2 (see McKelvey and others, 1953, p. $3)$. The carbonate content of the Retort Member, especially the upper phosphatic zone, is generally low in the weathered rocks, though doubtless higher below the zone of weathering.
The lower phosphatic zone is not thick enough or rich enough to be worth mining by itself. It contains half again as much alumina and ferric oxide as the upper zone because it is more shaly. The middle shaly zone contains about 9 percent alumina and 3 percent ferric oxide. The average content of these oxides in the whole member is nearly 7 percent in a ratio of about 2 to 1 .

For purposes of estimating phosphate resources, the Maxville district has been divided into the geologic blocks shown in figure 205; the tonnages in them are noted in table 10 . 
TABLE 10.-Phosphate resources in the Retort Phosphatic Shale Member of the Phosphoria Formation, Anaconda, Philipsburg, and Maxville districts, Montana

[Phosphate resources given in millions of short tons]

\begin{tabular}{|c|c|c|c|c|c|c|c|c|c|c|c|}
\hline \multirow{3}{*}{ Resource block } & \multicolumn{3}{|c|}{$\begin{array}{c}\text { Area (millions of sq } \mathrm{ft} \text { in plane } \\
\text { of bedding) }\end{array}$} & \multicolumn{3}{|c|}{ Basic Retort Member data } & \multicolumn{5}{|c|}{ Rock containing $>31$ percent $\mathrm{P}_{2} \mathrm{O}_{5}$} \\
\hline & \multirow{2}{*}{$\begin{array}{c}\text { Above } \\
\text { entry } \\
\text { level }\end{array}$} & \multirow{2}{*}{$\begin{array}{c}\text { First } \\
100 \mathrm{ft} \\
\text { below } \\
\text { entry } \\
\text { level }\end{array}$} & \multirow{2}{*}{$\begin{array}{l}\text { Total } \\
\text { block }\end{array}$} & \multirow{2}{*}{$\begin{array}{c}\text { Average } \\
\text { thickness } \\
(\mathrm{ft})\end{array}$} & \multirow{2}{*}{$\begin{array}{c}\text { Average } \\
\text { grade } \\
\text { (percent } \\
\left.\mathbf{P}_{2} \mathrm{O}_{5}\right)\end{array}$} & \multirow{2}{*}{$\begin{array}{l}\text { Total } \\
\mathrm{P}_{2} \mathrm{O}_{5}\end{array}$} & \multirow{2}{*}{$\begin{array}{c}\text { Thick- } \\
\text { ness } \\
\text { (ft) }\end{array}$} & \multirow{2}{*}{$\begin{array}{c}\text { Grade } \\
\text { (percent } \\
\mathrm{P}_{2} \mathrm{O}_{5} \text { ) }\end{array}$} & \multicolumn{3}{|c|}{ Tonnage } \\
\hline & & & & & & & & & $\begin{array}{c}\text { Above } \\
\text { entry } \\
\text { level }\end{array}$ & $\begin{array}{l}\text { First } 100 \\
\text { ft. below } \\
\text { eitry level }\end{array}$ & $\begin{array}{l}\text { Total } \\
\text { block }\end{array}$ \\
\hline Area north of Warm Springs Creek...... & 9.0 & 0.2 & 17 & 20.0 & 18.0 & 5 & & & & & \\
\hline Garrity Hill area............................. & 34.4 & 4.3 & 137 & 20.0 & 18.0 & 40 & & & & & \\
\hline Philipsburg area & 53.9 & 11.1 & 291 & 21.0 & 13. 0 & 75 & & & & & \\
\hline $\begin{array}{l}\text { Gird Creek syncline } \\
\text { Douglas Creek syncline }\end{array}$ & $\begin{array}{l}10.9 \\
50.0\end{array}$ & $\begin{array}{l}2.4 \\
8.0\end{array}$ & $\begin{array}{l}140 \\
513\end{array}$ & $\begin{array}{l}13.0 \\
12.0\end{array}$ & $\begin{array}{l}22.0 \\
22.0\end{array}$ & $\begin{array}{r}35 \\
100\end{array}$ & 4.0 & 32.0 & 4.0 & 0.9 & 50 \\
\hline Coberly syncline & 90.1 & 15.5 & 1,062 & 11.0 & 20.0 & 200 & 3.5 & 32.0 & 25.0 & 4.5 & 150 \\
\hline Gold Creek syncline & 17.8 & 3.4 & 834 & 10.0 & 20.0 & 150 & & & & & \\
\hline Totals and averages.................. & 266.1 & 44.9 & 2,997 & 12.7 & 19.6 & 605 & 3.6 & 32.0 & 29.0 & 5.4 & 200 \\
\hline
\end{tabular}

Rock containing $>24$ percent $\mathrm{P}_{2} \mathrm{O}_{5}$

Rock containing $>18$ percent $\mathrm{P}_{2} \mathrm{O}_{5}$

\begin{tabular}{|c|c|c|c|c|c|c|c|c|c|c|}
\hline \multirow[t]{2}{*}{ Resource block } & \multirow[b]{2}{*}{$\begin{array}{l}\text { Thickness } \\
\text { (ft) }\end{array}$} & \multirow[b]{2}{*}{$\begin{array}{c}\text { Grade } \\
\text { (percent } \\
\left.\mathrm{P}_{2} \mathrm{O}_{5}\right)\end{array}$} & \multicolumn{3}{|c|}{ Tonnage } & \multirow[b]{2}{*}{$\begin{array}{l}\text { Thickness } \\
\text { (ft) }\end{array}$} & \multirow[b]{2}{*}{$\begin{array}{c}\text { Grade } \\
\text { (percent } \\
\left.\mathbf{P}_{2} \mathrm{O}_{5}\right)\end{array}$} & \multicolumn{3}{|c|}{ Tonnage } \\
\hline & & & $\begin{array}{c}\text { A bove } \\
\text { entry } \\
\text { level }\end{array}$ & $\begin{array}{l}\text { First } 100 \\
\text { ft below } \\
\text { entry level }\end{array}$ & $\begin{array}{l}\text { Total } \\
\text { block }\end{array}$ & & & $\begin{array}{l}\text { Above } \\
\text { entry } \\
\text { level }\end{array}$ & $\begin{array}{l}\text { First } 100 \\
\text { it below } \\
\text { entry level }\end{array}$ & $\begin{array}{l}\text { Total } \\
\text { block }\end{array}$ \\
\hline $\begin{array}{l}\text { Area north of Warm Springs Creek } \\
\text { Garrity Hill area } \\
\text { Philipsburg area } \\
\text { Gird Creek syncline } \\
\text { Douglas Creek syncline. } \\
\text { Coberly syncline } \\
\text { Gold Creek syncline. }\end{array}$ & $\begin{array}{l}6.5 \\
6.5 \\
6.5 \\
5.0 \\
5.0 \\
5.0 \\
5.0\end{array}$ & $\begin{array}{l}28.0 \\
28.0 \\
26.0 \\
29.0 \\
29.0 \\
28.0 \\
26.0\end{array}$ & $\begin{array}{r}5.0 \\
20.0 \\
30.0 \\
5.0 \\
20.0 \\
40.0 \\
8.0\end{array}$ & $\begin{array}{l}0.1 \\
2.5 \\
6.5 \\
1.0 \\
3.5 \\
7.0 \\
1.5\end{array}$ & $\begin{array}{r}10 \\
80 \\
150 \\
60 \\
200 \\
450 \\
350\end{array}$ & $\begin{array}{l}7.5 \\
7.5 \\
6.5 \\
8.0 \\
8.0 \\
8.0 \\
8.0\end{array}$ & $\begin{array}{l}25.0 \\
25.0 \\
26.0 \\
28.0 \\
26.6 \\
24.0 \\
24.0\end{array}$ & $\begin{array}{r}6.0 \\
20.0 \\
30.0 \\
7.5 \\
30.0 \\
65.0 \\
10.0\end{array}$ & $\begin{array}{r}0.1 \\
2.5 \\
6.5 \\
1.5 \\
5.5 \\
10.0 \\
2.5\end{array}$ & $\begin{array}{r}10 \\
90 \\
150 \\
95 \\
350 \\
750 \\
600\end{array}$ \\
\hline Totals and averages................. & 5.2 & 27.6 & 128.0 & 22.1 & 1,300 & 7.8 & 24.9 & 168.5 & 28.6 & 2,045 \\
\hline
\end{tabular}

The structure in this area is a major factor in assessing the economic potential of this district. It consists of a series of nearly isoclinal folds that lean westward, plunge gently northward, and are displaced by nearstrike faults. Many of the faults dip east and are downthrown on the east. McGill (1959) regarded them as steep reverse faults that were overturned. Mutch and Gwinn (1960); however, believed that the folds and thrust faults were overturned by compression from the east and then displaced by east-dipping normal faults.

The west side of the Maxville district is bounded by a large thrust fault that was regarded by Calkins as a downfolded segment of the Philipsburg thrust, but the writer believes that this may be a segment of the Georgetown thrust extending northward from the Philipsburg stock (see p. 796).

The fold pattern in this area is dominated, from west to east, by the Princeton, Douglas Moutain, and Dunkleberg Ridge anticlines. These anticlines separate the four major synclines containing Permian rocks, from west to east, the Gird Greek, Douglas Creek, Coberly, and Gold Creek synclines, each of which contains faults and smaller folds.

The Permian rocks in the southern part of the Maxville district are preserved only in the synclines, so the phosphate resources of the entire area are calculated and are discussed in terms of the synclinal blocks, a synchinal block being regarded as extending from one anticlinal axis to the next (fig. 205). How far northward down the plunge of these folds the thickness and grade of the phosphate rock remain essentially constant is of course uncertain. As no comparable phosphorite beds have been found in the nearest part of the Garnet Range, projection of estimates across the Clark Fork valley would not be justified; however, the general persistence of stratigraphic units, as indicated by measurements in the Maxville area, seems to warrant their being projected at least to the north boundary of T. $9 \mathrm{~N}$., which, therefore, has been selected arbitrarily as limiting the area for which phosphate resources are estimated.

\section{GIRD CREEK SYNCLINE}

The Gird Creek syncline is truncated on the west by a thrust fault, here interpreted (pl. 34A) as the northward continuation of the Georgetown thrust. Its east limb is interrupted by a small anticline regarded by Pardee (1936) as a west branch of the Princeton anticline. Between Gird and Douglas Creeks are two fault blocks that have been variously interpreted as downfolded or down-faulted segments of the Philipsburg thrust, but from the data presented on published maps, it appears likely that they are fault slices resulting from imbrication of the Georgetown(?) thrust.

The Retort Member was not measured or sampled within the Gird Creek syncline, but at the nearby East Edgar adit (lot 1389), which is on the east limb of the Princeton anticline a few hundred feet south of the 
northernmost exposure of Permian rocks, the member is nearly 14 feet thick and is estimated to contain an average of 23 percent $\mathrm{P}_{2} \mathrm{O}_{5}$ (pl. 33). It includes 7.5 feet of rock containing 29.5 percent $\mathrm{P}_{2} \mathrm{O}_{5}, 4$ feet of which contains 33.6 percent $\mathrm{P}_{2} \mathrm{O}_{5}$. At its base is a bed of phosphatic conglomerate 0.6 foot thick, but its most striking feature at this locality is a 3.4-foot bed, at its top, of sandy phosphorite containing 24.4 percent $\mathrm{P}_{2} \mathrm{O}_{5}$. This represents the upper sandy zone (see pl. 32), which is elsewhere much thinner and less phosphatic. The rocks at this locality are rather light colored and appear to be considerably weathered, so the proportion of phosphate probably decreases downward.

At the West Edgar mine, which is on the east edge of the Gird Creek syncline block, the phosphate beds are steeply dipping to overturned and are reached by a crosscut from the west; the mine produced little phosphate. The shallow workings were too much caved to be explored; but it was noted that some of the strata were considerably sheared.

\section{DOUGLAS CREEK SYNCLINE}

The Douglas Creek syncline, between the Princeton and Douglas Mountain anticlines, is crossed diagonally by Douglas Creek in the southern part of T. 9 N., Rs. 12 and $13 \mathrm{~W}$. Its axis plunges north about $10^{\circ}$. The fold is rather tight; the east limb is overturned and the west limb is steep.

This syncline is broken by two longitudinal faults. One is near its axis at the south end, and the other is on its east flank. The latter, called the Douglas Mountain fault, has the greater displacement and causes the Permian outcrop to be repeated for a distance of 5 miles. Although these faults dip steeply east and cause downthrow on the east, the writer believes them to be reverse faults that originally dipped steeply west but were later overturned, together with the axial planes of the folds. If this interpretation is correct, the faults can be be expected to steepen downward and finally to reverse their direction of dip.

Phosphatic beds of the Retort Member have been explored extensively along the flanks of the Douglas Creek syncline. Much exploration was by adits less than 200 feet long; none are known to have been productive. Information on the thickness and $\mathrm{P}_{2} \mathrm{O}_{5}$ content of the phosphorite is available for most of the localities ( $\mathrm{pl}$. 33). At two, lots 1387 and 1389, the full thickness of the Retort Member was measured and sampled. At most localities, the upper phosphatic zone includes at least 3 feet of rock containing more than 24 percent $\mathrm{P}_{2} \mathrm{O}_{5}$, and, as already noted, the zone contains more than 31 percent at the East Edgar mine (lot 1389). At two localities, the lower phosphatic zone averages more than 18 percent $\mathrm{P}_{2} \mathrm{O}_{5}$ in a thickness of 3 feet. As the exposed strata are generally weathered, the phosphate content probably decreases somewhat downward.

\section{COBERLY SYNCLINE}

The Coberly syncline occupies most of the west half of T. 8 and 9 N., R. 12 W., and extends southward into the narrow zone between the Philipsburg and Royal stocks, where it is less than 2 miles wide. In the northern part of T. 9 N., it is about 4 miles wide. Southward, it is split longitudinally by a sharp anticline, called by Pardee (1921) the Royal anticline. Permian rocks crop out on the limbs of this anticline for about 4 miles, and also on the outer limbs of the syncline for a distance of as much as 10 miles.

The eastern branch of the Coberly syncline is very narrow, and it appears to join the western branch in the southern part of T. $9 \mathrm{~N}$., where the Royal anticline apparently dies out by a combination of steeper plunge and strike faulting. In the southern part of T. $8 \mathrm{~N}$., the Royal stock has cut out about a mile of Permian rocks from the east flank of this syncline. The strata near the stock are also sharply overturned and bent westward.

The western branch of the Coberly syncline is very narrow south of Princeton Gulch (middle of T. $8 \mathrm{~N}$.) but gradually widens northward. West of its axis, in the southern part of T. 9 N., it is cut by several strike faults, regarded by Gwinn (1961) as east-dipping reverse faults; they have caused multiple repetition of the strata near the top of the Kootenai Formation. A fault at the east side of this group, called by McGill (1959) the Mount Princeton fault, has been traced for more than 5 miles. It was regarded by McGill as a reverse fault dipping west, but by Gwinn as a normal fault dipping east; in either case the downthrow is on the east, being thus opposed to that of the other faults in the group. In the south-central part of T. 9 N., near the axis of the Dunkleberg Ridge anticline, Gwinn has mapped two normal faults alternating with two reverse faults, all dipping steeply east. The easternmost, the Dunkleberg Creek fault, is normal and has been traced across most of T. $9 \mathrm{~N}$. All the faults trend a little to the left of the fold axis and extend northward into the eastern half of the Coberly syncline.

Gwinn (1961) and Mutch (1961) mapped diorite sills in the area between the axial parts of the Coberly and the Gold Creek synclines. These sills are chiefly in the upper (post-Kootenai) part of the Lower Cretaceous section and in some places are fairly thick. They are locally but not everywhere conformable with the strata and are similarly folded and faulted. They have produced little metamorphism in the enclosing sedimentary rocks. 
Gwinn recorded much overturning of the strata toward the west in the vicinity of the Coberly syncline. All these structural features occur in the rather incompetent Cretaceous rocks; they are one thousand to several thousand feet above the Permian, which is near the top of a more competent sequence, and it is uncertain how closely the structure at the surface reflects that of the underlying Permian rocks. The structure can be expected to die out in some degree with depth; the structure contours on plate $34 \mathrm{~A}$ indicate that it does so, but they must be considered as generalized. On plate $34 \mathrm{~A}$, faults and fold axes are plotted in terms of surface location. This has been necessary because the dips of the faults and axial planes cannot be projected reliably to the depth of the Permian rocks. The contouring is thus slightly distorted, but on the scale of the map it is still useful for depicting the major structure, which is basic to estimation of phosphate resources.

The Retort Member has been explored at many places on the west flank of the Coberly syncline (pl. 33), but no information is available on the thickness or character of the phosphatic strata in other parts of this structure. At all the localities examined (lots 1388, 1399, 1340, and Little Gold Creek, the upper phosphatic zone includes 3 feet or more of rock that contains more than furnace grade, and at two of those localities it contains rock of acid grade. The lower phosphatic zone includes thin but fairly high-grade phosphorite beds, and generally contains as much as 18 percent $\mathrm{P}_{2} \mathrm{O}_{5}$ for a thickness of 3 feet. At some localities the entire phosphatic shale member, which is about 10 feet thick, contains more than 24 percent $\mathrm{P}_{2} \mathrm{O}_{5}$.

Though all this information is from the west limb of the Coberly syncline, the general persistence of strata over this part of the Flint Creek Range (see pl. 32) makes it reasonable to expect comparable thickness and grade in most other parts of that fold. Some significant local variations are suggested by an apparent thinning of the strata southward in the Moonlight mine and by the relative thinness of the section measured in a reconnaissance north of Little Gold Creek (lot 1340). At the latter place, however, the beds are not well exposed, and at both places they may have been thimed by shearing.

Of perhaps greater concern from the mining standpoint is the proximity of the southern part of the syncline, especially the east branch, to the Royal stock, which has doubtless metamorphosed the phosporite as well as the other rocks. At Little Gold Creek, about a mile from the intrusive contact, the carbonate beds below the Retort Member are in fact altered to tremolitic marble, and although there is no conspicuous metamorphism within the Retort Member itself at that locality, the phosphorite closer to the contact may be more in- tensely metamorphosed. Pardee (1918b) reported that the gastropod-bearing limestone of the Kootenai Formation is altered to hornfels at the Wasa mine, on the crest of the Dunkleberg Ridge anticline in sec. $34, \mathbf{T}$. 9 N., R. 12 W., from which he infers that "intrusive granitic rock is present not far below the surface."

Some of the phosphate rock in the Coberly syncline moreover, has undoubtedly been spoiled by shearing in places where beds are faulted and tightly folded; shearing has been noted at some sample localities, and numerous minor faults are likely to be found in mining. In most of the area, however, these structural complications are not likely to be troublesome.

Deep middle Tertiary weathering has had considerable effect on the physical condition of the phosphatic shales in some parts of the area; at the Moonlight mine, for example, the phosphorite layers are friable and the mudstones soft and clayey. The rock is easily broken, therefore, but the footwall is so soft that it is difficult to avoid dilution. Weathering has resulted, on the other hand, in some removal of soluble constituents, and it has facilitated treatment by loosening the bonds between grains.

The phosphatic beds have been explored underground at the Moonlight mine on the south side of Princeton Gulch, and a small tonnage of phosphate rock was mined. The beds were also explored on both sides of Douglas Creek by the International Minerals and Chemical Corp. The main adit, on the east limb of the Douglas Mountain anticline and north of Douglas Creek, was driven about 1,650 feet along the strike in 1944-45 and was connected by several stopes to a much shorter adit about 175 feet higher. The phosphate rock was put through a small experimental mill (since dismantled) on the rail spur at Sherryl, near the moutl of Doug]as Creek. No information is available on the tonnage and grade of the rock mined or the results of the mill tests.

The lease on the Douglas Creek mine area is now held by the Montana Phosphate Products Co.; several adits have been developed on the limbs of the Douglas Mountain anticline and a 300,000 tons-per-year capacity flotation plant has been constructed. The concentrates are shipped to fertilizer plants in Canada.

\section{GOLD CREEK SYNCLINE}

The Gold Creek syncline is east of the Dunkleberg Ridge anticline and north of the Royal stock, at the northeast corner of the Flint Creek Range, in T. 8 and 9 N., R. 11 and 12 W. It is about 4 miles long and has a very blunt southern terminus against the stock. On its east side the Mesozoic strata are turned up abruptly and underlie upper Paleozoic strata in an east-dipping im- 
bricated thrust zone (Mutch, 1961). The thrust slices, have been folded into a northeast-plunging syncline, presumably due to uplift resulting from forceful emplacement of the stock. The surficial deposits of the Deer Lodge and Clark Fork Valleys overlap this syncline on the east and northeast and completely conceal the bedrock geology for several miles in those directions.

The geologic structure is most complex in the southwest corner of the Gold Creek synclinal area, which includes several miles of outcrop of Permian rocks; much of the Permian rock is well above entry level. The geology of this area has been mapped by Calkins (Calkins and Emmons, 1915), by McGill (1959), and by Mutch (1961). The broad picture is basically similar on their three maps, but the details differ. Mutch and McGill (1962), in a reinterpretation of the geology of this area (pl. 34A), show both east- and west-dipping reverse faults near the axis of the Dunkleberg Ridge anticline, east-trending fold axes on the east flank of the anticline immediately north of the Royal stock, and a normal fault transecting these minor folds half a mile to a mile east of the main axis.

Across the blunt south end of the Gold Creek syncline, Permian rocks occur very near the north edge of the Royal stock. At its southeast comer, Permian and associated strata were cut off by the east-dipping imbricated thrust zone, which in turn was cut off by the Royal stock, and Mutch and McGill (1962) believed that forceful intrusion of the stock caused plastic deformation, which has affected both the folds and the faults.

Metamorphism was noted by Pardee (1918b) near the Wasa mine, and Mutch and McGill (1962, p. 1542) have described an aureole of contact-metamorphosed sedimentary rocks near the Royal stock. Within half a mile of the contact, these rocks are of the albite-epidote hornfels facies, and within a few hundred feet of it, rocks of the hornblende hornfels facies occur in discontinuous zones.

Information is not available regarding the thickness or quality of the phosphate in the Retort Member in the Gold Creek syncline, from which no phosphate has been mined, but it seems likely, on the basis of information from localities on the west flank of the Coberly syncline, 2 or 3 miles to the west, that the Gold Creek syncline contains a minable thickness of phosphate rock well above furnace grade, and that some may be of acid grade. However, the Permian rocks in the imbricated fault zone on the east are likely to be strongly sheared, and so may those in the thrust-faulted east flank of the Dunkleberg Ridge anticline. Near the Royal stock, moreover, the phosphatic shales of the Retort Member may be so altered that they would be hard to mine, and the phosphate rock so indurated that it would be hard to treat in the mill. The strata may also be offset by small cross faults.

\section{PENDANT SYNCLINE}

The Pendant syncline, so named because it projects downward between the Mount Powell, Philipsburg, and Royal stocks, extends along the west side of the Mount Powell stock from the northeastern part of T. $7 \mathrm{~N}$. to the southwestern part of T. 6 N., R. $12 \mathrm{~W}$. It is considered to be of potential economic interest for phosphate, and for that reason it is described here as a separate area. The syncline as a whole is 2 miles wide near the north end, less than a quarter of a mile wide near the middle, and about half a mile wide near the south end. Permian rocks underlie an area almost 11 miles long.

The topographic relief on the Permian outcrops within the syncline is about 2,500 feet, the altitudes of outcrops being less than 7,000 feet at Racetrack Creek and more than 9,000 feet on Racetrack Peak and Goat Mountain. Two miles south of Racetrack Creek these rocks cross the ridge east of Twin Peaks at about 9,000 feet, and near the south end of the syncline they are 7,700 to 8,500 feet above sea level.

Detailed examination of the rocks in this area was not included in this study; this description is based largely on the mapping by Calkins (Emmons and Calkins, 1913, pl. 1). The Pendant syncline is split at the north end into two branches by a small but sharp south-plunging anticline. Both branches are asymmetric, the west limbs being steep and partly overturned. This composite synclinal structure is bounded on the east by the Mount Powell stock and on the west for most of its length by a westward-dipping reverse fault. The south end of the syncline is broken by two cross faults and one longitudinal fault.

No direct information is available on the quality of the phosphate in this area, but the nearest sample localities (lot 1337 to the south, lot 1340 to the northwest, and lot 1386 to the west) contain minable thicknesses of at least furnace-grade rock. Although phosphorite was seen in float and on old prospect dumps near the top of the ridge south of the Powell mine, west of Racetrack Peak, exposures suitable for measurement and description of stratigraphy were not found; the rocks have been altered to hornfels but have the characteristic phosphate bloom on weathered surfaces. Metamorphism has probably not had much effect on the chemical composition of the phosphate rock, but it has made the rock so hard that mining, and perhaps treatment, might be difficult. It seems probable that this syncline contains much furnace-grade phosphate rock of minable thickness 
above entry level. Transportation to the nearest railway would be long, however, and the winters would be severe.

\section{GARRISON DISTRICT}

The Garrison district lies entirely within the Garnet Range and includes the Avon district of Pardee (1936). (See pl. $34 B$ ). The district includes the area underlain by Permian rocks and is in T. 9 to 11 N., R. 9 to 14 W. The Garnet Range, which trends west-northwest, is separated from the north-trending Flint Creek Range by the synclinal depression that coincides with the valley of the Clark Fork. It is bordered on the east by the broad Avon Valley in which Permian rocks are concealed.

The Garnet Range, in contrast to the high rugged Flint Creek Range, is a rolling upland having few peaks above 7,000 feet and none above 7,500 feet. The phosphate deposits are almost all on the south side, and their outcrops are mostly less than 2,000 feet above the Clark Fork. The range contains no natural lakes; most of the phosphate area is well drained by short deeply incised streams that lead to the Little Blackfoot River or Clark Fork.

The Garrison district is at the northwest corner of that part of Montana that contains Permian rocks. Al- though the Permian seas and the sediments that accumulated in them doubtless extended much farther, much of the area west and north of the district has been so deeply eroded that the only rocks now exposed are those of the Precambrian Belt Supergroup. Paleozoic formations in the Garnet Range have a regional dip to the south and crop out as a zone generally less than 12 miles wide along the southern border of a large area of Beltian rocks. They are truncated westward by erosion and extend only a few miles west of the district. They are overlain by a thick sequence of Mesozoic rocks that fills the Clark Fork synclinal trough. Sills and small stocklike bodies, mostly consisting of diorite or quartz diorite (Gwinn, 1961), occur along the south flank of the Garnet Range. Volcanic rocks make up part of the thick Cretaceous sequence, and middle Tertiary volcanic rocks unconformably overlie the older formations in the central part of the range, overlapping the Permian beds in some places.

\section{STRATIGRAPHY OF PERMIAN ROCKS}

The general stratigraphy of the Permian rocks of the Garnet Range is similar to that of the Flint Creek Range, but there are some noteworthy differences. Sections were measured and sampled at four locations (tables 11-14). The Permian is thinner there than in the

TABLE 11.-Measured sections and analyses of Retort Phosphatic Shale Member of Phosphoria Formation in Luke mine, Montana, lot 1285

[Section measured and sampled by M. R. Klepper, September 1948, on 5300 level of Luke mine, sec. 15, T. 10 N., R. 9 W., Powell County, Mont. Iocality is on southwest limb of Luke-Graveley syncline; beds strike about N. $40^{\circ} \mathrm{W}$. and dip $45^{\circ} \mathrm{NE}$. Locality A is in southeast heading; locality $\mathrm{B}$ is in northwest heading. Samples analyzed for $\mathrm{P}_{2} \mathrm{O}_{3}$ and acid-insoluble by U.S. Bur. Mines and for uranium by U.S. Geol. Survey. Field notes and hand specimens lost]

\begin{tabular}{|c|c|c|c|c|c|c|c|}
\hline \multirow{2}{*}{ Bed } & \multirow{2}{*}{ Description } & \multirow{2}{*}{$\begin{array}{c}\text { Thickness } \\
\text { (feet) }\end{array}$} & \multirow{2}{*}{ Sample } & \multicolumn{2}{|c|}{ Chemical analyses (percent) } & \multicolumn{2}{|c|}{ Uramium content (percent) } \\
\hline & & & & $\mathrm{P}_{2} \mathrm{O}_{5}$ & $\begin{array}{r}\text { Arid } \\
\text { insoluble }\end{array}$ & eU & $\mathrm{U}$ \\
\hline \multicolumn{8}{|c|}{ LOCALITY A } \\
\hline \multicolumn{8}{|c|}{ Retort Phosplatic Shale Member of Phosphoria Formation } \\
\hline Rt-7 & Quartzite, cherty & 4. 0 & & & & & \\
\hline $6+\ldots$ & Phosphorite & .02 & 305-MRK & 34.0 & 9.3 & 0.012 & 0.009 \\
\hline $4 \ldots-1$ & (1) do & 1. 6 & $304-M R K$ & 35.5 & 5.8 & .012 & .010 \\
\hline .... & ................. & .1 & 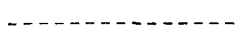 & $\ldots \ldots$ & ...- & ...... & \\
\hline \multicolumn{8}{|c|}{ Lower tongue of Shedhorn Sandstone } \\
\hline LS-2 & Quartzite & $\begin{array}{l}\text { 2. } 0 \\
\text { 4. } 0\end{array}$ & $\ldots \ldots+\ldots$. & $\ldots$ & -. & $\ldots$ & \\
\hline
\end{tabular}

LOCALITY B

Retort Phosphatic Shele Member of Phosphoria Formation

\begin{tabular}{|c|c|c|c|c|}
\hline 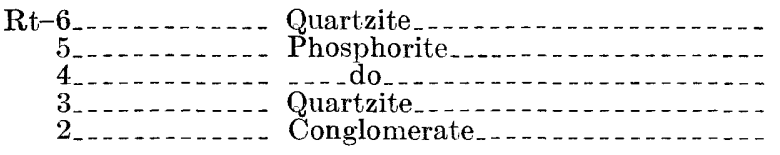 & $\begin{array}{ll}1.5 & \\
1.6 & 307-\mathrm{MRK}_{\mathrm{K}} \\
1.6 & 306-\mathrm{MRK} \\
.3 & \ldots \\
.5 & \ldots\end{array}$ & 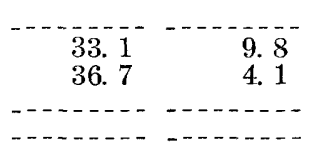 & 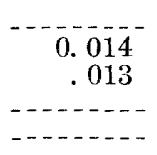 & $\begin{array}{r}0.008 \\
011 \\
-\cdot-\cdot-\cdot-\end{array}$ \\
\hline \multicolumn{5}{|c|}{ Tonguc of Park City Formation (?), top bed } \\
\hline
\end{tabular}


TABLE 12.-Measured sections and analyses of Permian rocks in Graveley mine, Montana, lot 1286

[Sections at localities A and B measured in Graveley mine on northeast limb of Luke-Graveley syncline, sec. 2, T. $10 \mathrm{~N}$., R. 9 W., Powell County, Mont., by M. R. Klepper September 1948; beds strike about N. $70^{\circ} \mathrm{W}$. and dip $50^{\circ} \mathrm{SW}$. Locality A is in 4906 stope; locality $\mathrm{B}$ is in 5101 west heading. Samples analyzed for $\mathrm{P}_{2} \mathrm{O}_{5}$ and acid insoluble by U.S. Bur. Mines, for uranium by U.S. Geol. Survey, and for other constituents by sources cited by Gulbrandsen (1966). Section at locality $C$ measured and described by and hand specimens for localities A and B lost]

\begin{tabular}{cccccc}
\hline Bed & Description & Thickness & Sample & Uranium content (percent) & Acid \\
\hline
\end{tabular}

\section{LOCALITY A}

Retort Phosphatic Shale Member of Phosphoria Formation

\begin{tabular}{|c|c|c|c|c|c|c|c|}
\hline 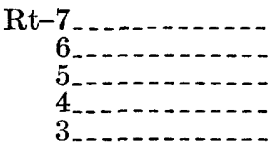 & $\begin{array}{l}\text { Chert } \\
\text { Clay }\end{array}$ & $\begin{array}{l}0.05 \\
1.3 \\
1.0 \\
1.25\end{array}$ & $\begin{array}{l}299-\mathrm{MRK} \\
298-M R K \\
297-M R K\end{array}$ & $\begin{array}{l}35.0 \\
37.5 \\
37.4\end{array}$ & $\begin{array}{r}10.2 \\
8.4 \\
4.6\end{array}$ & $\begin{array}{r}0.016 \\
015 \\
014\end{array}$ & $\begin{array}{r}0.010 \\
.010 \\
.010\end{array}$ \\
\hline
\end{tabular}

LOCALITY B

Retort Phosphatic Shale Member of Phosphoria Formation

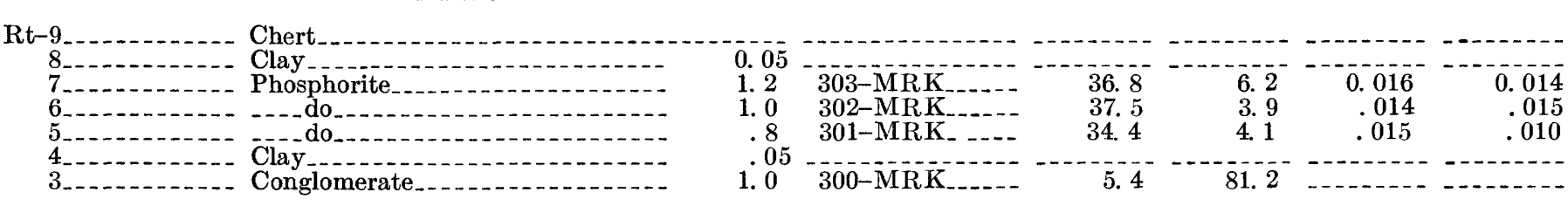

Lower tongue of Shedhorn Sandstone, top beds

LS-2 Sandstone.

\begin{tabular}{|c|c|c|c|c|c|}
\hline \multicolumn{6}{|l|}{1 Other constituents: } \\
\hline & $\stackrel{297-}{M R}$ & $\stackrel{299-}{M R K}$ & & $\stackrel{297_{-}}{M}$ & $\stackrel{299-}{M R K}$ \\
\hline $\mathrm{SiO}_{2} \ldots \ldots \ldots$ & 5.4 & 10.9 & $\mathrm{CO}_{2-}$ & .91 & .88 \\
\hline $\mathrm{Al}_{2} \mathrm{O}_{3}$ & 1.2 & .75 & & $\begin{array}{r}.23 \\
378\end{array}$ & 35 \\
\hline $\begin{array}{l}\mathrm{Fe}_{2} \mathrm{O}_{3} \\
\mathrm{MgO}\end{array}$ & $\begin{array}{l}1.3 \\
.00\end{array}$ & $\begin{array}{l}1.2 \\
.04\end{array}$ & Organic & & \\
\hline $\mathrm{CaO}$ & 50.0 & 46.5 & matter a & .2 & .3 \\
\hline $\mathrm{Na}_{2} \mathrm{O} \ldots \ldots . . .$. & .19 & .20 & Oil b. & .18 & .12 \\
\hline $\mathrm{K}_{2} \mathrm{O} \ldots \ldots$ & .31 & .28 & $\mathrm{Ag}$ & $<.00001$ & .0001 \\
\hline $\mathrm{H}_{2} \mathrm{O}$ total..... & .84 & 1.0 & As... & $<, 001$ & $<.001$ \\
\hline $\mathrm{H}_{2} \mathrm{O}$ & .2 & .2 & B............ & $<.005$ & $<.005$ \\
\hline $\mathrm{TiO}_{2} \ldots$ & .09 & .06 & $\mathrm{Ba}$ & .03 & .01 \\
\hline
\end{tabular}

a Organic matter by partial combustion. Loss of weight, in percent, between

LOCALITY C

Bed Thickness $\quad$ Description

Jurassic rocks, basal bed:

J-9 smooth.

Upper tongue of Shedhorn Sandstone:

US-8_.. 22.0 Quartzite and chert: quartzite: hard, light-brownish-gray $(10 Y R \quad 6 / 1)$ to pale-brown (10YR 6/2), thick- to very thick bedded, fine-grained. Chert: sandy, hard, dark-gray $\left(\begin{array}{ll}N & 4\end{array}\right)$ to yellowish-gray $(10 Y R \quad 8 / 1)$; occurs as layers and as matrix and irregular masses in quartzite; spicular at base; at top, darker and contains fine pyrite; basal contact irregular.

Retort Phosphatic Shale Member of Phosphoria Formation:

Rt-7... 1. 1 Mudstone: medium-hard, moderatebrown $(5 Y R 4 / 4)$ to very pale orange $(7.5 Y R \quad 8 / 2)$, fissile to thin-bedded; contains thin beds of hard very paie brown $(10 Y R, 7 / 2)$ fine-grained sandstone.

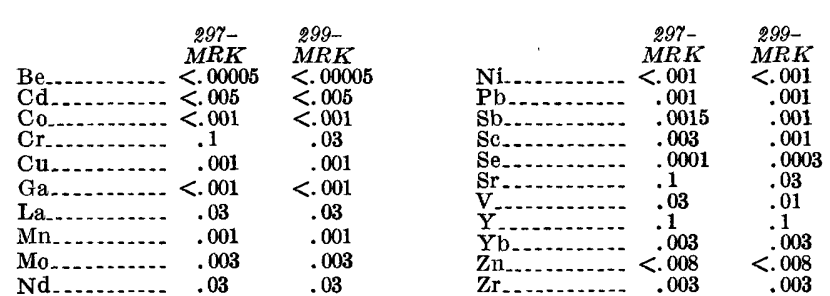

$\mathrm{b}$ Oil by distillation at about $500^{\circ} \mathrm{C}$ of distillate weighed.
Description

Retort Phosphatic Shale Member of Phosporia Formation-Con. Rt-6... 2.6 Sandstone and phosphorite: hard medium-gray $(N 5)$ medium-pelletal sandy phosphorite grades up into hard yellowish-gray $(10 Y R$ 7/1) fine- to medium-grained phosphatic sandstone; one bed; locally cherty.

5._. . 2 Mudstone: calcareous, phosphatic, medium-hard, very pale brown $(10 Y R$ $7 / 3$ ) ; contains $0.02-f t$ layer of very fine grained sandstone in middle.

4... 3. 0 Phosphorite: hard to medium-hard, darkgray $(N \quad 4)$ to medium-gray $(N \quad 5)$, thick- to very thick bedded, mediumpelletal to oolitic; contains some carbonate and some fine quartz sand; clay seam at base.

3... . 4 Conglomerate: composed of chert and quartzite pebbles (up to $2 \mathrm{~cm}$ ) in hard light-brownish-gray $(10 Y R \quad 6 / 1)$ to medium-dark-gray (N4) fine- to medium-grained phosphatic sandstone and sandy phosphorite. 
TABLE 12.-Measured sections and analyses of Permian rocks in Graveley mine, Montana, lot 1286-Continued LOCALITY C-Continued

Thickness
(feet)

Lower tongue of Shedhorn Sandstone:

LS-2_.. 3. 3 Sandstone: hard, pale-brown $(2.5 Y 6 / 2$, $7.5 Y R 6 / 2)$, locally medium-gray (N5), very thick bedded, fine- to mediumgrained; contains fine chert grit at base; basal contact gradational.
Bed Thickness Description

Tongue of Park City Formation, top bed:

PC-1 5. 0 Carbonate rock: hard, pale-brown $(2.5 Y$ $6 / 2,10 Y R 6 / 2)$, thick- to very thick bedded, ( 0.2 to $2 \mathrm{ft})$; aphanitic; contains fine chert grit and some chernodules near top, locally silty.

TABLE 13.-Measured sections and analyses of Permian rocks in Anderson mine, Montana, lot 1287

[Sections at localities A and B measured on 4800 level of Anderson mine on southwest limb of Garrison anticline, secs. 2 and 3 , T. $10 \mathrm{~N}$. R. R. $10 \mathrm{~W}$., Powell County, Mont., by
M. R. Klepper, October 1948; beds strike about N. 30 $\mathrm{M}$. R. Klepper, October 1948; beds strike about $\mathrm{N}$. $30^{\circ} \mathrm{W}$. and dip $30^{\circ} \mathrm{SW}$. Locality $\mathrm{A}$ is 100 feet south of north heading; locality $\mathrm{B}$ is 150 feet south of crosscut from shaft.
Samples analyzed for $\mathrm{P}_{2} \mathrm{O}_{5}$ and acid insoluble by $\mathrm{U}$. S. Bur. Mines, and for other constituents by U.S. Geol. Survey and the sources cited by Gulbrandsen (1966). Section Samples analyzed for $\mathrm{P}_{2} \mathrm{O}_{5}$ and acid insoluble by $\mathrm{U}$.S. Bur. Mines, and for other constituents by U.S. Geol. Survey and the sources cited by Gulbrandsen (1966). Seetion
at locality $\mathrm{C}$ was measured and described by $\mathrm{R}$. W. Swanson, June and August 1954; beds $Q-1$ through $\mathrm{Rt}-15$ from $5352-\mathrm{A}$ crosseut, beds $\mathrm{Rt}-16$ through $\mathrm{R} t-21$ from 5200 at locality $\mathrm{C}$ was measured and described by R. W. Swanson, June and August 1954; beds Q-1 through Rt-15 from 5352-A crosscut, beds Rt-16
drift 10 feet southeast of crosscut, and beds Rt-22 through J-25 from 5200 crosscut. Field notes and hand specimens for localities A and B lost]

\begin{tabular}{|c|c|c|c|c|c|c|c|}
\hline \multirow{2}{*}{ Berd } & \multirow{2}{*}{ Description } & \multirow{2}{*}{$\underset{\text { (feet) }}{\text { Thickness }}$} & \multirow{2}{*}{ Sample } & \multicolumn{2}{|c|}{ Chemical analyses (percent) } & \multicolumn{2}{|c|}{ Uranium content (percent) } \\
\hline & & & & $\mathrm{P}_{2} \mathrm{O}_{5}$ & $\underset{\text { insoluble }}{\text { Acid }}$ & $\mathrm{eU}$ & U \\
\hline
\end{tabular}

LOCALITY A

Retort Phosphatic Shale Member of Phosphoria Formation

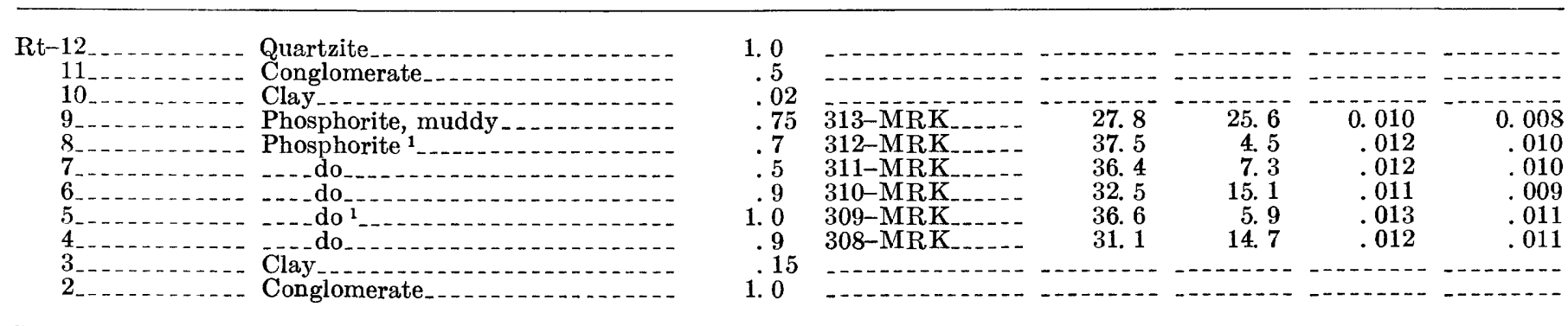

Lower tongue of Shedhorn Sandstone, top bed

LS-1 Sandstone

2. 0

\section{LOCALITY B}

Retort Phosphatic Shale Member of Phosphoria Formation

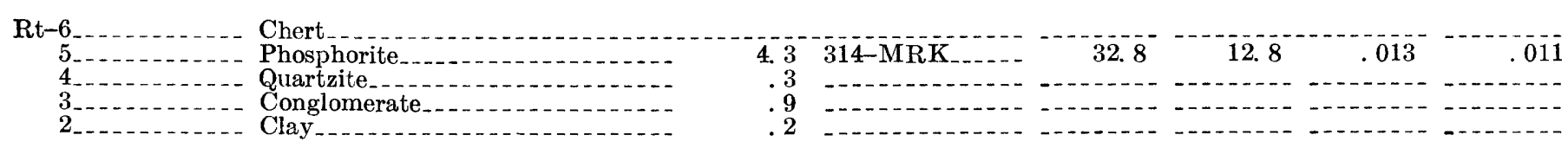

Lower tongue of Shedhorn Sandstone, top bed

LS-1 . . . . . . . . Sandstone and chert

2.0

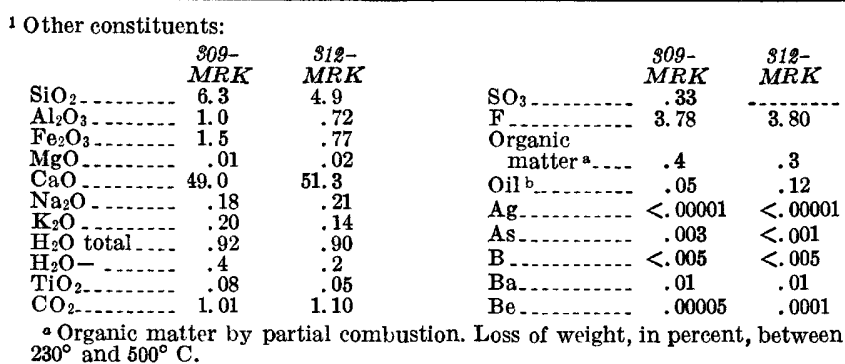

\begin{tabular}{|c|c|c|c|c|c|}
\hline & $309-$ & 318- & & $809-$ & $312-$ \\
\hline $\mathrm{Cd}$ & MRK & MRK & & $M R K$ & $M R K$ \\
\hline & $<.001$ & $<.001$ & & .001 & $\begin{array}{r}<.001 \\
.001\end{array}$ \\
\hline $\mathrm{Cr}$. & .1 & .1 & Se & .001 & .001 \\
\hline $\mathrm{Cu}$. & .003 & .003 & $\mathrm{Se}$ & .0003 & .0005 \\
\hline $\mathrm{Ga}_{-.-}$ & $<.001$ & $<.001$ & Sr. & .1 & .1 \\
\hline La... & .03 & .03 & $\mathrm{~V}$. & .03 & .03 \\
\hline Mn. & .003 & .003 & $\mathbf{Y}$ & .1 & .1 \\
\hline Mo... & .003 & $<.0005$ & Yb. & .001 & .001 \\
\hline Nd.. & .03 & .03 & $\mathrm{Zn}$ & $<.008$ & $<.008$ \\
\hline $\mathrm{Ni}_{-}$ & .003 & .003 & $\mathrm{Zr}$. & .003 & .003 \\
\hline
\end{tabular}


TABLE 13.-Measured sections and analyses of Permian rocks in Anderson mine, Montana, lot 1287 LOCALITY C

$\begin{array}{cc}\text { Bed } & (\text { feet }) \\ \text { Jurassic rocks, basal bed: }\end{array}$

J-25 ......... Shale: calcareous, medium-hard, darkgray $(N 3)$; basal contact fairly planar.

Tosi Chert Member of Phosphoria Formation:

T-24_... 8.0 Chert: sandy to locally quartzitic, hard, medium-dark-gray ( $N 4$ ), poorly bedded; contains gypsum crystals along joints; basal contact irregular to gradational.

23... . . .5 Quartzite: cherty, hard, medium-gray $(N 5)$, one bed, fine-grained; contains fine pyrite and and irregularly distributed chert.

Retort Phosphatic Shale Member of Phosphoria Formation:

Rt-22_._ $\quad 3.5$ Quartzite: hard, light-brownish-gray (10$Y R$ 5/1), fine- to medium-grained; contains much phosphate as fairly uniformly distributed pellets and oolites (15 percent?).

21 _. .5 Quartzite: hard, dark-gray $(N 3)$ to lightbrownish-gray (10YR 5/1), thin-bedded, medium-grained; contains small chert pebbles; contains pelletal and nodular phosphate, especially abundant above middle of unit; basal contact irregular, knobby.

20_- 1.0 Phosphorite: hard, dark-gray $\left(\begin{array}{ll}N & 3\end{array}\right)$, 19. 6 medium-pelletal; one bed.

Phosphorite: muddy, medium-hard, palebrown $(10 Y R 5 / 3)$, fissile to thin-bedded

finely to coarsely pelletal and oolitic.
18_-_ Phosphorite: medium-hard, medium-darkgray $(N 4)$, thin- to thick-bedded, finely pelletal; porous; contains thin shale seam in middle.

17_-_ 1.4 Phosphorite: medium-hard, medium-darkgray $(N 4)$, finely pelletal.

16_._. . 4 Phosphorite: sandy, medium-hard, medium-dark-gray $(N 4)$, one bed, finely pelletal; sand is fine.

15_._ 1. 35 Sandstone: conglomeratic, hard, yellowishgray $(10 Y R 7 / 1)$ to light-brownish-gray $(10 Y R 6 / 1)$, one bed, fine- to mediumgrained; porous; contains chert pebbles as much as $25 \mathrm{~mm}$ in diameter and many dark sand grains; contains phosphate pellets and nodules in uppermost $0.2 \mathrm{ft}$.

Tongue of Park City Formation:

PC-14_._ 2.4 Siltstone: cherty, medium-hard to soft, pale-brown (10YR 6/1) to very pale orange $(10 Y R$ 8/2), poorly bedded; harder and more cherty toward top; very porous; apparently was silty cherty limestone from which carbonate has been leached.

13_.- 1.1 Chert: silty, hard, vuggy, medium-gray $\left(\begin{array}{ll}N & 5\end{array}\right)$ to medium-light-gray $(N \quad 6)$; very porous; contains light-yellowishbrown (10YR 6/4) to very pale orange $(10 Y R 8 / 2)$ silty masses; unit apparently leached of carbonate; basal contact irregular.

$12 \ldots . .3$ Siltstone: soft, yellowish-gray $(10 Y R 8 / 1)$, one bed; very porous; may have been silty limestone; basal contact gradational.
Bed Thickness $\quad$ Deet) $\quad$ Description

Tongue of Park City Formation-Continued

PC-11... 1. 3 Siltstone: cherty, hard, light-brownishgray (10YR 5/1), one bed; porous; chert occurs as small irregular darkgray $(N 3)$ to medium-light-gray $(N 6)$ fragments; basal contact somewhat irregular.

10..- 1.6 Siltstone: cherty, hard, light-brownishgray (10YR 5/1), one bed; porous.

9._. . .85 Siltstone: cherty, soft to medium-hard, friable, grayish-orange (10YR 7/4), one bed; porous; chert yellowish-gray (10YR 8/1); contains secondary(?) coarse quartz grains; basal contact

8_._- 2.2 $\begin{gathered}\text { irregular. } \\ \text { Siltstone: } \text { soft, yellowish-gray }(10 Y R 7 / 1)\end{gathered}$ to very light gray ( $N$ 8); very porous; bedding indistinct; composed almost entirely of quartz, mostly medium- to coarse-silt size; cherty in part; contains some fine mica; basal contact irregular.

7...- $\quad 3.6$ Siltstone: soft to medium-hard, yellowish-gray (10YR 8/1), poorly bedded; very porous: contains some mica; contains small chert fragments throughout but mostly in uppermost $0.5 \mathrm{ft}$; basal contact irregular to gradational.

6...2 2.2 Siltstone: cherty, soft to medium-hard, yellowish-gray $(10 Y R$ 8/1) with ironstained liesegang rings, thick-bedded; very porous; contains fine mica; basal contact irregular.

Lower tongue of Shedhorn Sandstone(?):

LS?-5.. 1.1 Sandstone grading laterally into chert: sandstone: hard, pale-brown (7.5YR $6 / 2$ ), medium-grained; chert; sandy, hard, medium-gray $\left(\begin{array}{l}N \\ 5\end{array}\right)$ to lightgray $(N 7)$; occurs as fragments and pebbles $1 / 2$ to $25 \mathrm{~mm}$ diameter; basal contact irregular.

4..- 1. 0 Quartzite: hard, medium-gray $(N 5)$ to light-brownish-gray $(10 Y R 6 / 1)$, finegrained; contains dark material between grains.

Quadrant Quartzite, upper part:

Q-3.... 11.0 Quartzite: hard, vitreous, very light gray ( $N$ 8), massive, medium-grained; contains some dark grains and many dull clay-like grains; basal contact gradational.

2...- 4. 0 Quartzite: hard, medium-dark-gray ( $N$ 4), one bed, fine-grained; contains numerous light-gray $(N 7)$ to yellowish-gray $(10 Y R 8 / 1)$ round spots $1 / 2$ to 1 inch in diameter, and unit locally called "spotted dog" quartzite (Bell and Moore, 1965, p. 67); basal contact gradational.

1...- 65土 Quartzite: hard, vitreous, light-gray ( $N$ 7), medium-grained. 
TABLE 14.-Measured section and analyses of Permian rocks near Warm Springs Creek, Mont., lot 1402

[Section measured and described by R. W. Swanson, July 1954, in prospect pit and natural exposures on northwest side of valley about 300 feet above Warm Springs Creek in SE1/4 SW1 4 sec. $19, \mathrm{~T}, 10 \mathrm{~N}, \mathrm{R}, 9 \mathrm{~W}$. Powell County, Mont. Beds strike about N. $55^{\circ} \mathrm{W}$. and dip $65^{\circ}$ SW. Samples analyzed for $\mathrm{P}_{2} \mathrm{O}_{5}$ and acid insoluble by U.S. Bur. Mines and for organic matter and uranium by U.S. Geol. Surveyl

$$
\text { Bed Thickness } \begin{gathered}
\left(f_{e t} t\right) \\
\text { Description }
\end{gathered}
$$

Tosi Chert Member of Phosphoria Formation, top not exposed: To-16_.. 23.0 Chert and quartzite: hard dense lightgray $(N 7)$ to very pale brown $(10 Y R$ $7 / 2)$ and light-brownish-gray $(10 Y R$ 5/1) sandy chert and hard mediumgray $N 5$ ) to light-brownish-gray (10YR 6/1) fine- to medium-grained cherty quartzite; unit thick bedded to massive and lithologies intergrade; contains disseminated pyrite and veinlets of fluorite and quartz; basal contact gradational.

15... 3.5] Chert and quartzite: similar to To-16, but chert medium bluish gray $(5 B 5 / 1)$ and quartzite medium gray $\left(\begin{array}{l}N \\ 5\end{array}\right)$; unit poorly bedded.

14_.- 1.6 Chert and quartzite: similar to To-16; contains dark phosphate(?) grains; contains clear fluorite crystals on joint surfaces.

Retort Phosphatic Shale Member of Phosphoria Formation:

Rt-13_._ 1.1 Quartzite and chert: like beds above but more quartzite, thick bedded; contains medium-pelletal phosphate and disseminated iron and copper sulfides.

12b_- 2.1 Quartzite: phosphatic, similar to Rt-13 but contains more phosphate.

12a.- . 3 Phosphorite: sandy, hard, dark-gray ( $N$ 3), medium-pelletal to nodular nodules composed of pellets in aphanitic matrix; basal contact irregular.

11... . 75 Phosphorite: siliceous, hard, mediumdark-gray (N 4) to light-brownishgray $(10 Y R 5 / 1)$; medium- to coarsely pelletal; one bed; containes fine quartz sand, very fine secondary quartz, pyrite, and fluorite; basal contact gradational.

10_._. 75 Phosphorite: hard, medium-dark-gray $(N$ 4), thin-bedded medium- to coarsely pelletal; contains very fine pyrite, and veinlets of purple fluorite.
Thickness
(feet)

Retort Phosphatic Shale Member of Phosphoria Formation-Con. Rt-9... 0.25 Phosphorite: hard, medium-dark-gray $(N 4)$, very thin bedded, medium- to coarsely pelletal; contains quartz silt and fine sand; contains fluorite and pyrite, mostly disseminated, and very fine quartz erystals visible under high magnification.

8...- 1. 3 Phosphorite: hard, medium-dark-gray $(N$ 4), one bed, medium- to coarsely pelletal; contains quartz-fluorite veinlets and very fine secondary quartz(?) around pellets; basal contact gradaational.

7.... . 85 Phosphorite: hard, medium-dark-gray (N 4), one bed, medium- to coarsely pelletal; contains purple fluorite veinlets.

6b_-_ . 1 Mudstone: phosphatic, medium-hard, yellowish-gray $(10 Y R$ 8/1) to very pale brown $(10 Y R 7 / 2)$, fissile, finely to medium-pelletal.

6a... . .3 Phosphorite: hard, medium-dark-gray $(N$ 4), thin-bedded, coarsely pelletal and aphanitic.

5b_-_ . 1 Phosphorite: sandy, hard, dark-gray $(N 3)$ to medium-gray $\left(N^{\prime} 5\right)$, mediumpelletal; contains fluorite.

5a_.. 1.0 Quartzite: conglomeratic, hard, mediumdark-gray (N 4), thick-bedded, medium-grained; contains chert pebbles as much as $25 \mathrm{~mm}$ in diameter and phosphate pellets; basal contact irregular.

Lower tongue of Shedhorn Sandstone:

LS-4_._ 2.9 Quartzite: hard, medium-gray $\left(\begin{array}{ll}N & 5\end{array}\right)$ and medium-dark-gray $(N 4)$, lightbrownish-gray $(10 Y R \quad 6 / 1)$ in lower part, poorly bedded, fine-grained; contains pale-brown $(2.5 Y 6 / 2)$ sandy mudstone near base; basal contact irregular.

3..._ 26. 0 Chert, sandy, and cherty quartzite: poorly exposed.

2... 1. 0 Siltstone and cherty quartzite.

Quadrant Quartzite:

Q-1_... 80.0土 Quartzite: flinty.

\begin{tabular}{|c|c|c|c|c|c|c|c|}
\hline \multirow{2}{*}{ Bed } & \multirow{2}{*}{ Sample } & \multirow{2}{*}{$\begin{array}{c}\text { Thickness } \\
\text { (feet) }\end{array}$} & \multicolumn{3}{|c|}{$\underset{\text { (percent) }}{\text { Chemical analyses }}$} & \multicolumn{2}{|c|}{$\begin{array}{c}\text { Uranium content } \\
\text { (percent) }\end{array}$} \\
\hline & & & $\mathrm{P}_{2} \mathrm{O}_{5}$ & Acid insoluble & Organic matter & $\mathrm{eU}$ & $\mathrm{U}$ \\
\hline
\end{tabular}

Flint Creek Range, owing chiefly to northward thinning of most units in the course of deposition and to unequal pre--Jurassic erosion of the strata. These differences may also be partly related to right-lateral displacement along the Lewis and Clark line.
The lower part of the Permian strata in the Garnet Range consists of cherty sandstone correlated with the lower member of the Shedhorn Sandstone and of carbonate beds that represent a tongue of the Park City Formation. Silty layers in the Anderson mine (lot 1287) 
may record Park City strata that were leached of their carbonate during post-Permian erosion cycles.

Of the five zones into which the Retort Member of the Phosphoria Formation was divided in the Flint Creek Range (pl. 32), only three have been recognized in the Garnet Range - the lowest and the two highest. A fairly persistent thin bed of conglomeratic and locally phosphatic sandstone occurs at the base of the Retort Member and is correlated with the lower sandy zone of areas to the south; it apparently marks an unconformity that increases in magnitude northward, for it occupies the stratigraphic position that includes the much thicker sequence composed of the lower sandy, lower phosphatic, and middle shaly zones to the south. The 3 to 5 feet of phosphorite that overlies these beds is probably correlative with the upper phosphatic zone of the Flint Creek Range and the upper part of the Retort Member in the Melrose region (Cressman and Swanson, 1964). Farther west, the phosphorite seems either to pinch out or to grade into chert. The phosphatic zone is overlain by an upper sandy zone that is similar to the upper sandy zone in the Flint Creek Range.

Chert correlated with the Tosi Chert Member of the Phosphoria Formation is the dominant rock in the postRetort Permian of the Garnet Range area (pl. 31), but sandstone correlated with the upper member of the Shedhorn is common locally and seems to be more abundant westward. In the exposures at the sample localities, the contact between Permian and Jurassic strata is fairly concordant, but it is at various distances above the Retort phosphorite, and it marks a major unconformity.

No detailed geologic maps of the western part of the district are available, but reconnaissance maps of most of it were made by Pardee (1918a), and T. 11 N., R. 15 W. was mapped by Montgomery (1958). The writer visited the area briefly in search of outcrops worth sampling and has also drawn some inferences regarding its geology from the geologic map of Montana (Ross and others, 1955). The Permian rocks in this area are poorly exposed. Pardee (1917, p. 209, 223) measured a section at an unspecified locality west of Drummond that included as much as 131 feet of standstone, shale, and chert (pl. 31) and a partial section in sec. 23, T. 11 N., R. 13 W., some 3 miles north west of Drummond, that included about 20 feet of sandstone, chert, and shale, all slightly phosphatic. R. A. Gulbrandsen (oral commun., 1953) found about 35 feet of Permian rocks near Little Bear Creek, at the west end of the Mount Baldy syncline. East of the west branch of Little Bear Creek, in the northwest part of sec. 8, T. 11 N., R. 14 W., the writer also noted Quadrant, Shedhorn, and Ellis strata, dipping about $40^{\circ} \mathrm{SW}$. The Permian rocks observed there are mostly quartzitic sandstone with some thin beds of limestone. Their estimated thickness is 50 to 75 feet. The westernmost known occurrence of Permian rocks in Montana may be on the south flank of Mount Baldy, in sec. 12, T. 11 N., R. 15 W., where Montgomery (1958) found float of "characteristic sandstone and gray to black oolite [oolitic or oolite and (?)] chert" between the Quadrant and the Ellis.

The geology of the central part of the Garrison district was mapped by Pardee (1917, pl. 8), and parts of it have also been mapped by Gwinn (1961) and by Mutch (1961). All this mapping, however, was done on planimetric base. Some of the differences between their maps and plate $34 \mathrm{~B}$ of this report result from attempts to adjust their map data to topographic base. Pardee (1917, p. 223) measured a partial section on Hoover Creek, 6 miles northwest of the Anderson mine, and another on Burt Creek (Bert Creek on the modern topographic map), 10 miles west of that mine and 5 miles east of Drummond (pl. 32). On Hoover Creek, the Retort Member consists of 1 foot of coarsely oolitic to finely nodular sandy phosphorite containing 18.6 percent $\mathrm{P}_{2} \mathrm{O}_{5}$; it is underlain by 5 feet or more of chert, and that is underlain by an unmeasured thickness of quartzite. Cherty quartzite overlies the phosphorite. On Burt Creek, the Retort consists of sandy phosphorite which is only 7 inches thick, is coarsely nodular, and contains 16.29 percent $\mathrm{P}_{2} \mathrm{O}_{5}$. According to Pardee (1917, p. 223), it is underlain by 1 foot of slightly phosphatic sandstone, and that in turn by 2 feet of chert and at least 25 feet of "sandstone, slightly phosphatic." The phosphorite is overlain by at least 4 feet of quartzitic sandstone.

It is uncertain whether the sandy phosphorite at these localities should be correlated with the upper sandy zone of the Retort Member, as shown on plate 32, or with the upper phosphatic zone. It resembles more closely the upper sandy zone at localities farther east and also to the southwest (lot 1389). If it is in fact correlative with that zone, the underlying chert represents the upper phosphatic zone and indicates a rather abrupt change in facies. Such a change appears to occur eastward (Elliston localities, pl. 32). At the north edge of the Anderson mine, the phosphatic zone thins rather abruptly, and the overlying cherty rocks grade laterally into sandstone (C. O. Swanson and L. C. Bell, oral commun., 1953).

The east end of the Garrison district contains important phosphate deposits and has received much attention. Pardee (1913) found phosphate at Warm Springs Creek in 1911, and in 1913 he first mapped the area (Pardee, 1917, pl. 8). Later he revised his mapping of the eastern segment (Pardee, 1936, pl. 32). The maps by Gwinn (1961) and Mutch (1961) reach the southwest corner of this area, but neither map extends to the Permian outcrops. The following description is based 
largely on the above reports, but it also utilizes data gathered during this study. Additional data were supplied by C. O. Swanson and L. C. Bell (oral commun., 1953), geologists of the Montana Phosphate Products Co., who were most cooperative in making information available to the writer. The company also granted free access to its mines.

The thickest section of Permian rocks in the eastern part of the Garrison district is on Warm Springs Creek (lot 1402, pl. 31). This is a composite section, based partly on the work of Pardee (1917, p. 209). The Permian rocks at that locality are 85 feet thick, yet are only 36 feet thick at the Anderson mine, about 4 miles to the northwest. The section measured in that mine is also composite, having been pieced together from exposures along several crosscuts driven into the foot and hanging walls of the phosphate bed.

The contact of Permian rocks with the underlying Quadrant Formation was observed on the surface by the writer at both of the above localities, and it has been located underground with the diamond drill by company geologists. Although it seems nowhere to be marked by angular unconformity, this contact is probably a great disconformity, representing part of Pennsylvanian and much of Permian time. A characteristic feature of the upper part of the Quadrant in this area is the so-called spotted-dog quartzite (Bell and Moore, 1965 ), which serves as a good marker in diamond drilling. This is a bed of medium-dark-gray fine-grained quartzitic sandstone containing numerous rounded very light gray spots $1 / 2$ to 1 inch in diameter; they are commonly closely spaced. The origin of these spots is not known, but their occurrence in a bed near the top of the Quadrant suggests that they were formed near an erosional surface.

The Permian strata below the Retort Member in this eastern segment of the Garrison district represent an intertonguing of the lower member of the Shedhorn Sandstone and the Park City Formation near the depositional lap-out areas of these formations. The beds consist of cherty sand, silt, and carbonate rock. Their character varies considerably from place to place, but much of the variation appears to be due to weathering. At the Anderson mine, this sequence, which is well exposed in the 5352A crosscut (lot 1287), consists of sandstone, siltstone, and chert that are interbedded in widely varying proportions and grade into one another laterally. The sandstone is fine grained and generally cherty. The chert is mostly nodular, but some of it is distinctly bedded. The siltstone is both sandy and cherty, though the sand is very fine and the chert tends to be concentrated in certain layers. This rock is unusually soft and looks as if it might have been produced by the weather- ing of an impure carbonate rock-an impression that is partly confirmed by the presence of 5 feet of carbonate rock nearly 4 feet below the phosphorite at the Graveley mine (lot 1286). If the siltstone at the Anderson mine does consist of residue from a leached carbonate rock, the 18 feet of siltstone that underlies the Retort Member there may represent 30 feet or more of original strata.

At the base of the Retort Member in this area is a thin but persistent bed of conglomerate or conglomeratic sandstone that generally contains easily recognizable grains of phosphate. This bed ranges from 0.4 to 1.4 feet in thickness where measured during this study. It is in somewhat irregular contact with the bed below, which is usually sandstone, and the base of the overlying phosphorite is commonly sandy. Most of the pebbles are of spicular chert or quartzite and less than an inch long. The phosphate is mostly oolitic, but is partly pelletal or nodular and is commonly a little coarser than the sand, which is fine to medium grained. In general, the rock is somewhat porous.

In most of this area, the phosphate zone consists of a single bed of phosphorite 3 to 5 feet thick. This is considered the stratigraphic equivalent of the upper phosphatic zone in the Retort Member in the Flint Creek Range (pl. 32). The phosphorite is finely to medium coarsely pelletal to oolitic, and some of it also contains much structureless phosphate. Phosphate nodules are locally common in the sandy layers at the base and top of the phosphate zone. Shaly to clayey partings as much as an inch or more thick are common near the top and bottom of the zone, and one or more may occur in between. Some of the phosphorite, also, is thin bedded and appears somewhat argillaceous, though much of it is massive to blocky. When entirely fresh, the phosphorite is dark gray, but much of that exposed in this area is weathered and lighter colored.

Quartz grains are common in some places near the top and bottom of the phosphatic zone, but even there the middle part of the zone consists of high-grade phosphorite without much quartz or other impurity. The phosphate rock in this area is remarkably free from carbonate and contains little organic matter. Most of it consists almost wholly of apatite and acid-insoluble material.

The phosphorite in the Anderson mine (lot 1287) is of fairly uniform thickness, grade, and character, both along strike and downdip, but at the north edge of the property, along what is referred to at the mine as the "shoreline," its thickness decreases rather abruptly to a few inches (C. O. Swanson and L. C. Bell, oral commun., 1953). This thinning may mark the edge of an 
area that remained too high for the accumulation of phosphorite, or it may record uplift accompanied by erosion that occurred after the accumulation of the phosphorite and before the deposition of the overlying sandstone. Swanson and Bell have said that the overlying strata contain more sand and less chert there than elsewhere but are of about their usual thickness.

The phosphorite is overlain in some places by a bed of phosphatic sandstone or quartzite, as much as 4 feet thick, in which the sandstone is fine to medium grained and the phosphate generally medium coarsely oolitic. Much of the sandstone is cherty, and chert locally dominates over sand. Chert generally increases in abundance upward, and phosphate generally decreases. Small pebbles of chert and quartzite and nodules of phosphate are common in a basal bed, a few inches thick, that is apparently equivalent to the upper sandy zone of the Flint Creek Range and Elliston districts, where some of it is very phosphatic.

The Tosi Chert Member, which overlies the Retort Phosphatic Shale Member, is generally sandy but irregularly so, sand being dominant in some layers or patches within layers. At the Graveley mine, sand appears to be somewhat more abundant than chert but is very fine grained and has a cherty matrix.

At the Anderson mine, the Tosi Chert Member is only 8 feet thick and is overlain on a sharp apparently planar contact by dark-gray calcareous shale of the Ellis Group of Jurassic age. At Warm Springs Creek (lot 1402), according to Pardee $(1917$, p. 209), the phosphorite is overlain by 49 feet of chert, of which the writer saw all but the top 17 feet. At the Graveley mine, this chert is only 22 feet thick. Although the bedding appears to be parallel with that of the Ellis at all these localities, the variation in thickness of post-Retort Permian strata suggests that the underlying rocks were deeply eroded.

An unusual lithology found in mining the phosphate of this area is a coarse breccia of foreign rock materials, locally termed "wash" breccia, which occurs in zones extending as much as 400 feet along the strike and 850 feet downdip, according to the Canadian Mining Journal $(1954$, p. 197) :

The breccia commonly consists of a shaly and, more rarely, a sandy matrix enclosing the overlying rocks as angular fragments and as blocks, some of which are of huge dimensions. The inclusions consist mainly of the overlying Ellis shale and sandstone and to some extent of the reddish sandstones and shales of the Kootenai Formation. This would indicate that openings above the phosphate bed at one time extended up at least well into the Kootenai beds. A stratigraphic thickness of about 800 feet $^{2}$ of rocks overlying the Phosphoria can thus be assumed to have been involved in making up the breccia.

${ }^{2} \mathrm{~A}$ thickness of 650 to 700 feet may suffice, for at the 5,200 crosscut of the Anderson mine the Ellis is about 600 feet thick $(1,040$ feet wide at $35^{\circ}$ dip) and reddish sandstone occurs in the basal 100 feet of the Kootenai.
The concept of origin best fitting the observed facts appears to be that the breccia zones represent rapid filling of ancient stream channels. However, their presently known, somewhat haphazard distribution at the horizon of the phosphate bed cannot be said to establish this concept conclusively.

These breccia zones cut into phosphate reserves and interfere with mining operations; understanding of their origin could help indicate where they are likely to be found. The writer has seen some of the "wash" in the Anderson mine and was impressed by the absence of water-worn fragments and matrix sand that would reflect stream origin, and also by the apparent absence of debris from other than the Ellis and Kootenai Formations. These facts suggest an origin different from that proposed in the Canadian Mining Journal.

This explanation assumes that large solution caverns were formed in the underlying Mission Canyon Limestone (Mississippian), and that overlying strata collapsed into these caverns. The effects of such collapse would have had to extend upward through more than 1,000 feet of strata, for the Mission Canyon lies far below the Permian rocks, but there are several reasons for believing that this occurred.

Solution caverns near the top of the Mission Canyon are very common in Montana, and the available evidence indicates that this limestone was subjected to active solution several times in this area. The first was shortly after its deposition, before it was buried by the Amsden Formation (Sloss and Hamblin, 1942). Subsequently, solution probably occurred before and after deposition of the Permian strata, and before and after deposition of the sandstone of Jurassic (Bajocian) age (p. 783). At least two major periods of subaerial erosion have occurred since the Laramide folding and faulting. The first preceded accumulation of the middle Tertiary volcanic rocks of the Garnet Range, which unconformably overlie a surface of low to moderate relief that was not far above the present ridge tops near the Anderson mine. The second is the present cycle of erosion, which has cut deeply into the volcanic and older rocks. In addition to solution by circulating ground waters, solution by thermal waters has been extensive locally, indicated by travertine terraces still forming in the valley of Warm Springs Creek. The pre-Laramide cavern development was independent of the present structures and altitudes of the rocks, but post-Laramide solution has been controlled by such structures as well as by altitude.

Structural control is believed to have been a major factor in formation of the "wash" zones. The rocks in this area are extensively jointed, and small faults are numerous in some parts of the area. Well-developed joint systems not only favor circulation of ground water and cavern-forming solution of limestone. but thev also 
make possible extensive cavern roof collapse where major joint or shear zones intersect caverns in the Mission Canyon Limestone. There the intensely broken rocks would spall or cave readily, and such caving could extend to great heights along the shear zones. Much of this collapse probably would have occurred during earthquakes; these are common to the region and undoubtedly have been common through much of Tertiary and Quaternary time incident to the development of the fault-block structure and topography that characterizes western Montana (Pardee, 1950).

\section{STRUCTURE OF PERMIAN ROCKS}

The rocks in the Garnet Range occur in a series of southeast-plunging en echelon folds (pl. 34B) formed during the Laramide orogeny. These folds are tightest near the west end of the district and larger toward the east. The axial planes of the folds generally trend a little north of northwest in the eastern part of the district and a little west of northwest in the western part. Most of them are asymmetric, the steeper limbs of the anticlines being on the southwest. The dips of the Permian strata at the outcrops are generally less than $45^{\circ}$ but range from $20^{\circ}$ to overturned $55^{\circ}$ (Pardee, 1917, pl. 8). In most of the Garnet Range, the rocks are not as tightly folded as those on the north flank of the Flint Creek Range, and in general they are less faulted. Almost all the faults are normal and of small displacement. Permian rocks that crop out in the axial part of the Garrison anticline (T. 10 N., R. 9 W.) are displaced by small northeast-striking faults so numerous that they complicate mining operations (Pardee, 1917, pl. 8; 1936, pl. 32; Armstrong and McKay, 1949).

In the west end of the Garrison district, two synclines strike about N. $55^{\circ} \mathrm{W}$. and plunge gently southeast. The one at the southwest has been named the Mount Baldy syncline (pl. $34 B$ ), and the other, along which the Clark Fork runs for several miles, Clark Fork syncline. North of the Clark Fork, these are separated by the Bearmouth anticline. The area south of the Clark Fork is complexly faulted, and much of the bedrock geology is buried by volcanic rocks (Maxwell, $1965)$. The only Permian rocks that crop out south of the river are along the southwest side of the Clark Fork syncline within $11 / 2$ miles of the river; they are broken by many cross faults, and this limb was apparently thrust onto the Cretaceous rocks of the central part of the syncline. The Mount Baldy syncline does not appear to be identifiable south of the Clark Fork; the presence of Precambrian Belt rocks and of thrust faults may indicate that it has been overridden by a thrust plate. Northeast of the Clark Fork syncline is the Drummond anticline. Orerturned dips were found by Pardee (1917) on the sonthwest flank of the Drum- mond anticline, and by Montgomery (1958) on the west and southwest sides of the Mount Baldy syncline.

The geologic structure in the central part of the Garrison district is dominated by two broad open synclines, the Edwards Gulch on the west and the Carter Creek on the east (pl. $34 B$ ). The zone between is dominantly anticlinal but consists of several folds; from west to east these are the Limestone Ridge anticline (which is itself divided by the Bert Creek syncline), an unnamed syncline, the Saddle Mountain anticline, another unnamed syncline, and the Elk Swamp Creek anticline. All these folds plunge southeast at angles of $10^{\circ}$ to $20^{\circ}$.

The rocks of this central segment of the Garrison district are not much faulted, but Gwinn (1961) shows a few steep faults, generally short and of small displacement. Several trend northwest. One strikes about east and crosses the Bert Creek syncline and the east branch of the Limestone Ridge anticline; this and another small one near it are the only ones known to displace Permian rocks.

$A$ number of andesitic to diabasic sills and irregularly shaped intrusive bodies occur within the Cretaceous rocks of the area (Pardee, 1917; Gwinn, 1961; Mutch, 1961). Gwinn showed that two bodies of intrusive andesite cut across the Permian rocks near the nose of the Limestone Ridge anticline. Pardee (1917, p. 212, pl. 8) noted that several patches of andesitic lava cover the Permian rocks near the heads of Carter and Hoover Creeks, and Gwinn (1961) showed similar relations in the trough of the syncline between the Limestone Ridge and the Saddle Mountain anticlines.

Tertiary sedimenits, in part volcanic, cover many square miles from the Clark Fork to the nose of the Limestone Ridge anticline, and the river bottom is broadly alluviated.

The geologic structure in the eastern part of the Garrison district is dominated by the large rather bluntnosed Garrison anticline. Outcrops of Permian rocks on the two sides of this fold strike mostly about N. $35^{\circ} \mathrm{W}$. and are about $31 / 2$ miles apart. Those on the southwest side extend for 12 miles northwestward from the rather sharp bend of the outcrops near Warm Springs Creek to the axial part of the Carter Creek syncline, but those on the northeast side extend for less than 4 miles, then swing abruptly around the narrow Luke-Graveley syncline. The anticline plunges southeastward, and near the southeast end of the Permian outcrops, the plunge steepens and the axis bends eastward to a strike of about N. $70^{\circ} \mathrm{W}$.

On the northeast side of the Luke-Graveley syncline, Permian rocks are known to occur over a distance of about 3 miles, but that part near the axis of the syncline is covered by rhyolitic lava (Pardee, 1936). Pardee ( $p$. 
183) noted that the laras to the east are separated from the phosphate bed by a fault that strikes northwest. His map (pl. 32) shows no fault, though it does show the western boundary of the rhyolite area as fairly straight, which suggests that it is a fault contact. In his report on block faulting (Pardee, 1950, pl. 1), he noted a short fault at about this place and a much longer one 7 miles to the northeast, on the other side of the Avon Valley, both striking north of northwest. He indicated a downthrow on the southwest of at least 1,000 feet on the longer fault (p. 396), and the displacement on the shorter one may be nearly as great. Permian rocks, therefore, probably underlie part of the Avon Valley, but there is no reliable basis for judging the size of the area underlain by them or their depth below the surface.

The Garrison anticline, in the area where the Permian outcrop swings around the nose of the fold, is crossed by many steep normal faults that strike N. $15^{\circ}$ to $30^{\circ}$ E. and dip northwest (Pardee, 1917, pl. 8; 1936, pl. 32). These faults were probably formed late in the sequence of tectonic events, and seem to reflect clockwise (looking northeast) rotation of the blocks. One effect of this step faulting is to extend southeastward the area containing outcrops of the Permian rocks.

Many other faults have been found in the Luke mine, where, according to Armstrong and McKay (1949, p. 290 ), they occur "at fairly regular intervals of from 50 to 100 feet" and generally displace the phosphate bed 3 to 20 feet; according to the Canadian Mining Journal (1954, p. 201), displacements range from 3 to 50 feet. These faults strike N. $50^{\circ}$ to $80^{\circ} \mathrm{E}$., are normal, and dip for the most part moderately to steeply south, so their general effect is contrary to that of the larger faults mapped by Pardee.

At the Anderson mine, which is on the southwest limb of the Garrison anticline, the dip of the bedding is as low as $23^{\circ}$ in the upper workings but steepens downward to more than $40^{\circ}$ in a vertical distance of a little more than 1,000 feet (Canadian Mining Jour., 1954, p. 197). Where Warm Springs Creek crosses the southwest side of the anticline (lot 1402), the Permian strata dip $65^{\circ}$ at the surface, but the dip is considerably less in the Madison Limestone to the northeast and in the Cretaceous rocks to the southwest (Pardee, 1917, pl. 8). On the broad southeast-plunging nose of the anticline, the dips range from $15^{\circ}$ to $40^{\circ}$. At the Luke mine, on the northeast flank of the anticline, the dips are $40^{\circ}$ to $50^{\circ}$; at the Graveley mine, on the northeast flank of the Luke-Graveley syncline, the beds are nearly vertical in the upper workings but dip only $40^{\circ} \mathrm{SW}$. on the lowest level, about 1,000 feet below the surface (Canadian Mining Jour., 1954, p. 200).

\section{PHOSPHATE DEPOSITS}

Pardee (1913) found phosphate at Warm Springs Creek in the eastern part of the Garrison district shortly after the first discovery of phosphate in Montana, made by Gale (1911) near Melrose in 1910. The first underground work was started at the Anderson mine in 1923, but that mine did not produce any phosphate until 1929 (Canadian Mining Jour., 1954, p. 195). Five other mines in this area have since become productive.

The mines in the eastern part of the Garrison district had yielded by 1962 nearly 7 million tons of phosphate rock (Popoff and Service, 1965), more than all the rest of Montana. Nearly two-thirds of this has come from the Anderson mine (pl. 34B), the largest in the western phosphate field and the first to produce a large tonnage from below entry level; most of the remainder came from the Luke and Graveley mines. These and most of the other mines are operated by the Montana Phosphate Products Co. (Canadian Mining Jour., 1954, p. 198-201). The Relyea, Gimlet, and Bishop mines have produced smaller tonnages, and the new Brock mine is connected with, and is part of, the Anderson. Descriptions of these and other mines and prospects in the district are given by Popoff and Service (1965).

The phosphate bed in the eastern part of the Garrison district ranges in thickness from 2.7 feet at the Gimlet mine to an average of about 4.5 feet at the Anderson mine. It is 3 to 4 feet thick at the Graveley mine and 3 feet thick at the Luke mine (Canadian Mining Jour., 1954, p. 199-201). A maximum thickness of 4.75 feet was measured at the Anderson mine (lot 1287). Other measured thicknesses were 4.3 feet at Warm Springs Creek (lot 1402), 3.2 feet at the Luke mine (lot 1285), and 3.55 feet at the Graveley mine (lot 1286) (pl. 33). At most localities, 3 feet or more of phosphate rock contains more than 31 percent $\mathrm{P}_{2} \mathrm{O}_{5}$, and some contains more than 35 percent. The acid-insoluble content is less than 10 percent at the Luke and Graveley mines and in much of the phosphate rock at the Anderson mine, and the phosphate rock at all these localities contains little else than acid-insoluble material and apatite.

Most of the phosphate in this district occurs in a single zone of high-quality phosphorite. Shaly partings occur in some areas, and those at the top and bottom of the zone are commonly gougy. Some beds are of very high quality, particularly where leaching of soluble materials is evident, and the whole zone averages 32 to 36 percent $\mathrm{P}_{2} \mathrm{O}_{5}$ locally. In some places the lower and upper sandy zones contain enough phosphate to increase mining width. Pardee (1913, p. 290) described two such "cherty phosphate" beds near Warm Springs Creek; these could be mined with the main bed for furnace-grade use if they persist in grade and thickness. 
They are thinner and of lower grade at lot 1402, but even there a thickness of nearly 7 feet contains about 22 percent $\mathrm{P}_{2} \mathrm{O}_{5}$.

The Permian rocks in the vicinity of Warm Springs Creek are unusual in several ways. Most of the rocks there are unusually hard, as though silicified; both the sandstone and the phosphorite break like flint. The phosphorite also contains many small veinlets of purple fluorite, some veinlets of quartz, and much finely disseminated pyrite, and it is of lower grade and somewhat darker here than at other localities in the GarrisonAvon area. Although the acid-insoluble content is nearly 20 percent, which is about double the average for that area as a whole, the sum of apatite plus acidinsoluble material for the phosphate zone is only 93.6 percent, whereas it is nearly 100 percent at localities nearby.

All these features appear to point to hydrothermal activity, whose waning phases may be represented by the travertine still being deposited on the valley bottom. Silicification of the phosphorite would account for both the lower than average content of $\mathrm{P}_{2} \mathrm{O}_{5}$ and the higher than average content of acid-insoluble material. By reducing permeability, it would also retard the leaching out of organic matter and other soluble constituents by meteoric water; the survival of these, together with the deposition of secondary fluorite and pyrite, would help to account for the unusually dark color of the phosphorite and its low content of combined apatite and acid-insoluble material.

It is hard to judge how widespread this hydrothermal activity was, but the marked differences in $\mathrm{P}_{2} \mathrm{O}_{5}$ content of the phosphate zone in the measured section (Pardee, 1913,1917 ; lot 1402) suggest that the affected area was relatively small. It is important that these effects be recognized, for they not only lower the grade of the phosphorite but are likely to cause problems in mining and treatment.

It seems quite possible that the phosphate ore in the Garrison district is of unusually high average grade because of leaching of soluble diluents during weathering. C. O. Swanson and L. V. Bell of the Montana Phosphate Products Co. (oral commun., 1953), though, suggested that the uniform grade of the phosphate in individual mines, regardless of depth, is evidence that the abnormally low carbonate content of some of the phosphorite is a primary characteristic of the rock.

If weathering has been a factor in improving the quality of minable rock, some consideration should be given to the age of weathering and the distribution of weathered sections. Reasons were given in an earlier section for believing that the Permian rocks of this area have been subjected to several major periods of weather- ing during which carbonate could have been leached; two and perhaps three periods took place before tectonic deformation of the rocks and two after deformation. The earlier periods are reflected in part by the variations in thickness of the Permian strata above the Retort Member. The pre-Jurassic erosion of Permian strata was probably attended by considerable solution of carbonate in the underlying rocks; such solution would be unrelated to present structure and topography. Much of the carbonate in the strata between the Retort Member and the Quadrant Quartzite at the Anderson mine (see p. 816) may have been leached out during that earlier weathering. Carbonate is more abundant in the rocks at the Graveley mine, but this may be due to the thicker cover of Permian rocks there, as shown by plate 32 . Also, there must have been extensive solution of carbonate during the development of the post-Laramide erosion surfaces (see, for example, Pardee, 1917, p. 216), but that solution must have been related to the existing geologic structures, which were not very different from the present structure, and any enrichment of the phosphorites so caused can be expected to diminish with depth.

Little information is available regarding the stratigraphy and phosphate content of the Retort Member in the western two-thirds of the Garrison district, but the brief descriptions by Pardee (1917, p. 223) indicate that this area probably contains little or no minable phosphate. Some small bodies of such rock could be found, however.

It is hard to predict how much of the Garrison district might prove to be underlain by minable phosphate. In the Anderson mine the phosphorite thins abruptly northwestward, which indicates that the so-called "shoreline" trends southwestward, but the course of that feature below the mine workings is not known. For convenience, however, Brock Creek, near the center of T. 10 N., R. 10 W. (fig. 206), has been taken as the western boundary of the area for which resources are estimated. There may be a major east-trending shear zone farther south, and about 20,000 feet of Cretaceous rocks are present near the Clark Fork, so it seems inadvisable to project estimates very far south of the outcrops. Whether a shear zone exists cannot be determined until the geology of the area is more fully mapped, and perhaps not even then, for the rocks are so poorly exposed that a shear zone in them would be hard to recognize. The grade and thickness of the phosphorite south of such a zone would be quite uncertain. It seems probable that such a zone would cross the northern part of T. $9 \mathrm{~N}$. and that fairly reliable estimates of tonnage can be made for T. $10 \mathrm{~N}$. 


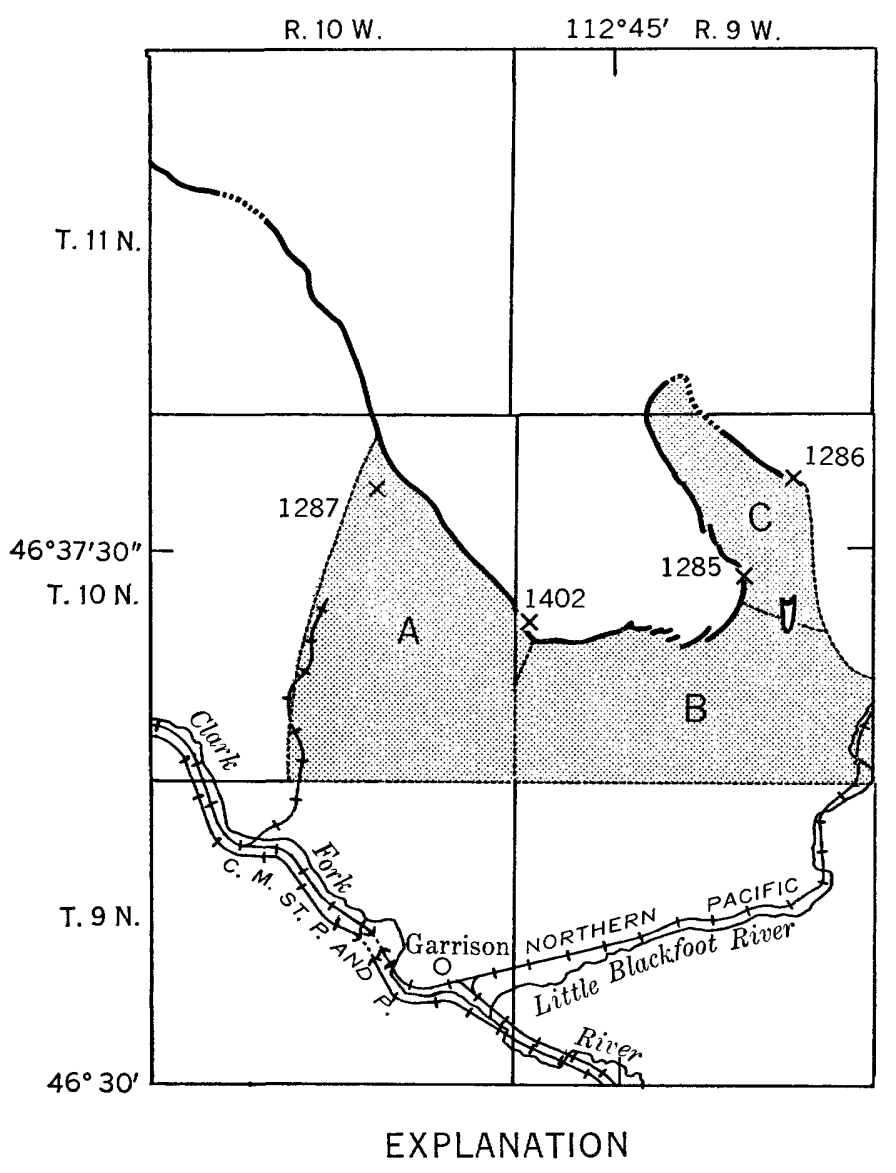

Outcrop of Permian rocks

Dotted where concealed or inferred

$$
x^{1286}
$$

Sample locality and lot number
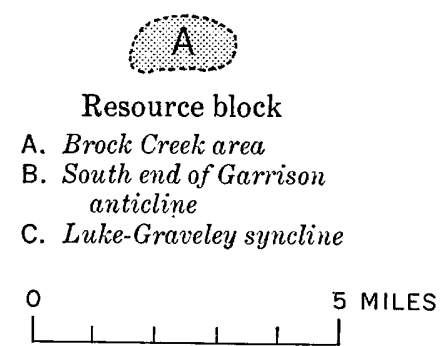

Figure 206.-Resource blocks in the eastern part of the Garrison district.

In the Avon Valley area to the east, the Paleozoic and Mesozoic rocks are covered by Tertiary sediments and volcanic rocks. According to Pardee (1936, p. 183), the volcanic rocks are downfaulted; although no fault is plotted on his map (pl. 32), the western boundary of the volcanic rocks is so straight that it looks like a fault contact. This boundary is taken as the eastern limit for estimation of resources (fig. 206, table 15). The
Garrison anticline has no well-defined axis, for it apparently is not a compressional fold but a tilted and uplifted block with sedimentary strata draped across its margins. The anticlinal axis mapped by Pardee (1936, pl. 32) and the township line between Rs. 9 and $10 \mathrm{~W}$. are utilized in subdividing the phosphate area in figure 206. The estimates noted apply to the tonnage remaining after the mining year of 1962.

The phosphate resources estimated for the Garrison district are listed in table 15. These are based on the data shown on plate $34 \mathrm{~B}$, calculated by blocks as shown in figure 206. Approximately 350 million short tons of phosphate rock having an average grade of 32 percent $\mathrm{P}_{2} \mathrm{O}_{5}$ is present. About 19 million tons of this lies above entry level. Popoff and Service (1965, p. 45-47) modified estimates of Pardee (1917) by subtracting 25 percent to reflect a bed only 3 instead of 4 feet thick, by adding for the Gimlet Creek area, and by deducting for rock mined, and they estimated resources above drainage level for the Garrison district of 32 million long tons of ore having 27.5 percent $\mathrm{P}_{2} \mathrm{O}_{5}$. The difference between 19 and 32 million tons reflects mainly a difference in defining drainage level and different thickness and grade cutoffs.

From the limited information available, it seems unlikely that any phosphate rock in beds of minable thickness occurs near outcrops of Permian rocks in the western part of this district. At Brock Creek, the mined phosphate is as much as 5 feet thick, but it thins rather abruptly near the East Fork of Brock Creek. The direction in which the thinning extends downdip from the lower levels of the Anderson mine is not known. If it trends much to the west, some of the lower part of the Carter Creek basin is probably underlain by phosphate of minable thickness and grade, but the depth of this material below the surface would probably make it unattractive for mining.

The north flank of the Flint Creek Range contains phosphate of minable thickness and grade whose $\mathrm{P}_{2} \mathrm{O}_{5}$ content does not appear to diminish markedly northward. There is no way of judging how far northward minable phosphate may extend into the structural trough under the valley of Clark Fork, but some of it may occur north of the river.

\section{ELLISTON DISTRICT}

Elliston is 20 miles west of Helena and 6 miles west of the Continental Divide, and the Elliston district (pl. $34 \mathrm{C}$ ) includes the area underlain by Permian rocks in T. 9-11 N., R. 6 and 7 W., near the northwest corner of the Boulder batholith. It is separated from the Garrison district to the west by the broad Avon Valley, beneath which the distribution of Permian rocks is unknown, and from the area containing Permian rocks near 
TABLE 15.-Phosphate resources in the Retort Phosphatic Shale Member of the Phosphoria Formation, Garrison district, Montana

[Phosphate resources given in millions of short tons]

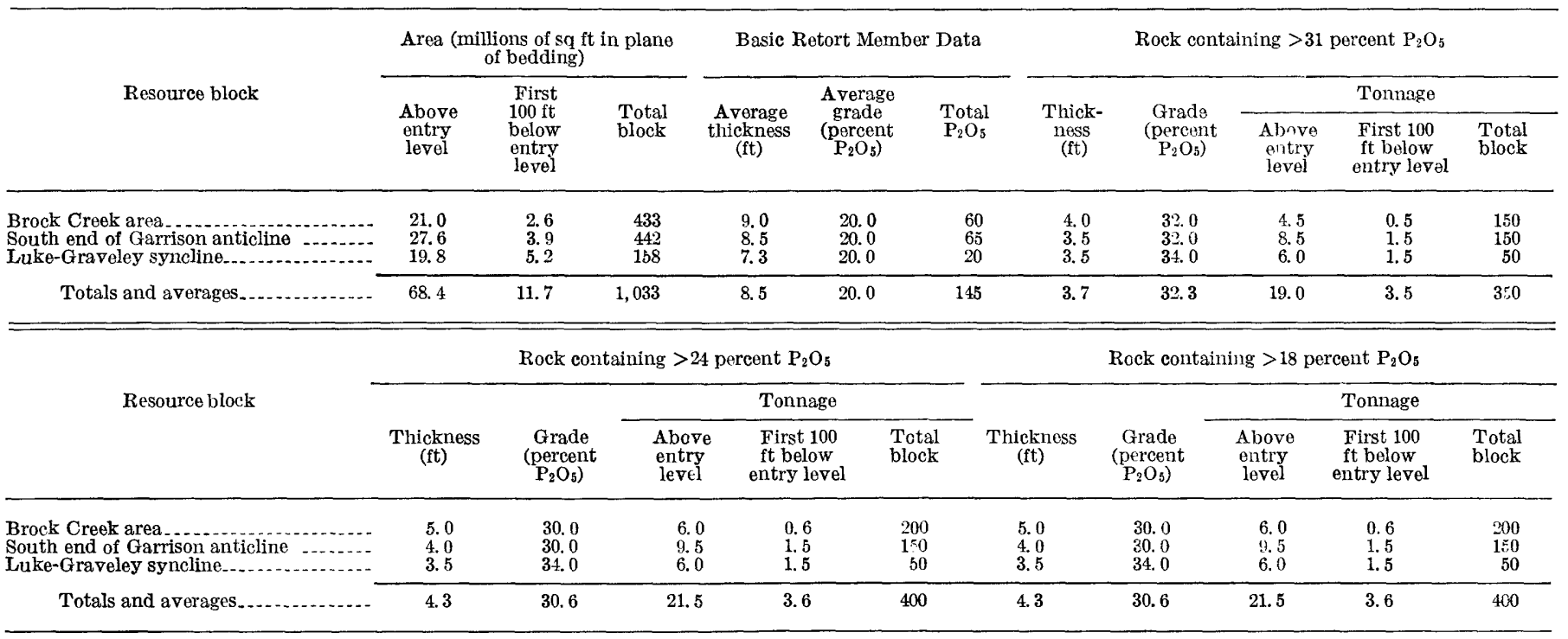

Helena by the northernmost prong of the batholith (pl. 30).

The phosphate deposits near Elliston were discovered by Pardee (1913) in 1911 and were investigated by Stone and Bonine (1914) in 1912. Much of the area was remapped by Jerome Stone (1952).

The Elliston district is geologically an eastward extension of the Garrison district, though separated from it by the broad Avon Valley which is occupied by younger rocks. The basic structure continues eastward, but the outcrops of the Mesozoic and most of the Paleozoic rocks, including the Permian, are interrupted by a northward extension of the Boulder batholith, about 8 miles wide, which forms the eastern boundary of the district. The folds in this area, as in the Garrison district, plunge southeastward and are cut off in that direction by the batholith. Permian and younger rocks probably underlie a significant area southwest of Elliston, but as most of that area is covered by volcanic rocks, which also conceal the western border of the batholith, little is known about its bedrock geology.

The stratigraphy of the Elliston district is much like that of the Garrison district and affords no further information about the strata above and below the Permian. In fact even the Permian rocks are incompletely known because none of the four sections that were measured (tables 16-19) or previous ones included exposures of the lower and upper contacts.

Stone and Bonine (1914, p. 375) assigned a thickness of 80 feet to what they regarded as the Phosphoria Formation, but this included 75 feet of soft greenishbrown sandstone and shale above the phosphorite, much of which is probably Jurassic (pl. 31, lot 1397). At the northwest corner of the town of Elliston (lot 1398), a section more than 30 feet thick was measured by the writer, but some beds there may have been cut out or repeated by a small fault. A mile east of the town (lot 1397) nearly 40 feet was measured. (See pl. 31).

The sections at localities 1397 and 1398 include 10 feet or more of strata beneath the main phosphorite, which probably represents most of the interval between the phosphorite bed and the Quadrant Quartzite. At each locality, about 3 feet of exposed cherty carbonate, the base of which is covered, is overlain by a like thickness of quartzitic sandstone that contains chert pebbles at the base and abundant phosphate pellets in the top 0.1 foot. These beds probably represent tongues of the Park City Formation and the Shedhorn Sandstone.

In the southern part of the Elliston district the lower part of the Retort Member contains several feet of shaly chert, with a thin bed of phosphorite at the base. The phosphorite is apparently equivalent to the lower phosphatic zone and the shaly chert to the middle shaly zone of the Flint Creek Range district, but the middle shaly zone is absent in the northern part of the Elliston district (lot 1 1400), as it is in the Garrison district.

The main phosphate zone is generally somewhat thinner and of lower grade in the Elliston district than in the Garrison district. It is also less uniform within small areas, possibly owing to a more shoreward environment of deposition or to lesser stability of the sea bottom. It is a mixture of pelletal and oolitic phosphorite and ranges from fine grained to very coarse grained. In the northern part of the district it immediately overlies a phosphatic sandstone layer at the 
TABLE 16.-Measured section and analyses of Permian rocks in pipeline trench near Elliston, Mont., lot 1897

[Section measured and described by R.W. Swanson, June 1954, in Billings-Spokane pipeline trench about 1 mile east of Elliston in NW1/4.SW1/4 sec. 6 , T. 9 N., R. 6 W., Powell County, Mont. Locality is on faulted south end of Elliston anticline; beds strike N. $30^{\circ} \mathrm{E}$. and dip $30^{\circ} \mathrm{NW}$. Samples analyzed for $\mathrm{P}_{2} \mathrm{O}$ and acid insoluble by U.S. Bur. Mines and for uranium by U. S. Geol. Survey]

\section{Thickness (feet)
Bed Description}

Tosi Chert Member of Phosphoria Formation and Upper tongue of Shedhorn, Sandstone, interbedded; top not exposed:

US-21... 4. 0 Quartzite.

To-20.. 10.8 Chert: locally quartzitic.

US-19.. $\quad .9$ Carbonate rock: sandy.

18.- 5. 0 Quartzite.

To-17_.. 2.6 Chert: contains mudstone parting $1.7 \mathrm{ft}$ above base.

16... 4 Limestone.

$15 . .10$ Chert.

Retort Phosphatic Shale Member of Phosphoria Formation:

Rt-14_.. . 7 Mudstone.

13c-. 2 Phosphorite: sandy, hard, brownish-gray $(10 Y R 4 / 1)$, poorly bedded, mediumpelletal and oolitic.

13b_- . 3 Sandstone: phosphatic, hard, light-brownish-gray $(10 Y R 6 / 1)$, poorly bedded fine-grained.

13a_- . 2 Phosphorite: sandy, calcareous, hard. light-brownish-gray (10YR 5/1), poorly bedded, medium- to coarsely pelletal and oolitic.

12... 2. 4 Phosphorite: hard, mostly medium-lightgray $(N 6)$ to light-brownish-gray $(10$ $Y R$ 6/1), coarsely oolitic, nodular at base; somewhat darker at top and bottom (light-gray oolites in darkbrownish-gray aphanitic phosphate matrix).

11_._. 2 Mudstone: cherty, medium-hard, very pale brown $(10 Y R 7 / 3)$.

$10 \ldots .5$ Chert: hard, brownish-gray $(10 Y R 3 / 1)$, one bed; contains mudstone parting at base.

9._. .6 Chert: hard, brownish-gray (10YR 3/1), one bed.

8... . 2 Mudstone and chert, interlaminated: hard, grayish-brown $(10 Y R 4 / 2)$ to light-brownish-gray $(10 Y R 5 / 1)$; mudstone contains phosphate pellets.

\section{Bed Thickness (feet) Description}

Retort Phosphatic Shale Member of Phosphoria FormationContinued

Rt-7_-_ 2.4 Chert: hard, light-brownish-gray (10YR 5/1), fissile to thin-bedded; contains mudstone partings at top and bottom and 0.15 -ft layer of hard pale-brown $(10 Y R \quad 5 / 2)$ cherty siltstone $1.5 \mathrm{ft}$ above base.

6...- 1.2 Chert: hard, dark-brownish-gray (10YR $3 / 1$ ), thin-bedded; contains pale-brown (10YR 6/2) mudstone partings $0.1,0.2$ and $0.7 \mathrm{ft}$ above base and $0.15 \mathrm{ft}$ interbedded fissile chert and mudstone at top; basal contact somewhat irregular.

5._._. . 3 Phosphorite: sandy, hard, brownish-gray $(10 Y R \quad 4 / 1)$ to light-brownish-gray $(10 Y R$ 5/1), one bed, medium- to coarsely pelletal and oolitic; sand is fine; much of phosphate is aphanitic. basal contact gradational.

4..._ . 2 Phosphorite: similar to Rt-5 but more sandy; basal contact gradational.

Lower tongue of Shedhorn Sandstone:

LS-3_-_ 2.6 Quartzite: hard, light-brownish-gray $(10 Y R 6 / 1)$ to pale-brown $(10 Y R 6 / 2)$ thick-bedded, fine-grained; contains chert pebbles in basal 0.1-ft; basal contact irregular.

Tongue of Park City Formation:

PC-2 _.. 1.5 Carbonate rock: cherty, hard, lightbrownish-gray $(10 Y R$ 6/1), thin- to thick-bedded; soft and iron-stained at top; locally contains small chert and fine-grained quartzite pebbles.

1... 1.1 Carbonate rock and chert: hard, lightbrownish-gray $(10 Y R 5 / 1)$ to very pale brown $(10 Y R 7 / 3)$, thin- to thickbedded. Covered below.

\begin{tabular}{|c|c|c|c|c|c|c|}
\hline \multirow{2}{*}{ Bed } & \multirow{2}{*}{ Sample } & \multirow{2}{*}{$\underset{\text { (feet) }}{\text { Thickness }}$} & \multicolumn{2}{|c|}{ Chemical analyses (percent) } & \multicolumn{2}{|c|}{ Uranium content (percent) } \\
\hline & & & $\mathrm{P}_{2} \mathrm{O}_{5}$ & Acid insoluble & $\mathrm{eU}$ & $\mathrm{U}$ \\
\hline Rt-13... & $\begin{array}{l}\text { 7474-RWS } \\
\text { 7473-RWS } \\
\text { 7472-RWS }\end{array}$ & $\begin{array}{r}0.7 \\
2.4 \\
.3\end{array}$ & $\begin{array}{l}\text { 14. } 1 \\
28.7 \\
28.2\end{array}$ & $\begin{array}{l}47.3 \\
19.3 \\
27.0\end{array}$ & $\begin{array}{l}0.003 \\
.008 \\
.007\end{array}$ & $\begin{array}{r}0.005 \\
.009 \\
.007\end{array}$ \\
\hline
\end{tabular}

TABLE 17.-Measured section and analyses of Permian rocks in Newman Brothers trench, Montana, lot 1898

[Section measured and deseribed by R. W. Swanson, June 1954, in bulldozer trench of Newman Brothers, NE1/4NE1/4 sec. 2, T. 9 N., R. 7 W., Powell County, Mont. Locality is in small fault block; beds strike north and dip $20^{\circ} \mathrm{W}$. Samples analyzed for $\mathrm{P}_{2} \mathrm{O}_{5}$ and acid insoluble by U.S. Bur. Mines and for uranium by $\mathrm{U}$.S. Geol. Surveyl

Thickness
Beet)

Tosi Chert Member of Phosphoria Formation, lower part

To-37_.- 4. 0 Chert: hard, pale-brown $(7.5 Y R 6 / 2$ to $10 Y R 5 / 2)$, fissile to thin-bedded; contains quartz and mica silt. 36... 8 Chert: hard, brownish-gray (10YR $3 / 1$ to
$10 Y R 4 / 1)$; one bed; contains very fine quartz sand.

35 1. 0 Chert: sandy, hard, brownish-gray $(10 Y R$ $3 / 1)$ to grayish-brown $(2.5 Y 4 / 2)$, one bed; sand is very fine.

34_- . 4 Chert: hard, light-brownish-gray $(10 Y R$ $5 / 1)$ to very pale brown $(10 Y R 7 / 2)$ fissile to thin-bedded; contains soft very pale orange $(10 Y R 8 / 2)$ mudstone partings; locally contains fine sand.

$$
\text { Bed Thickness (feet) Description }
$$

Tosi Chert Member of Phosphoria Formation, lower partContinued

To-33_- 0.4 Chert: hard, dark-gray $(N 3)$ to brownish-gray $(10 Y R$ 4/1); one bed; basal contact irregular to gradational. 32_. 7 Carbonate rock: hard, brownish-gray $(10 Y R$ 5/1), thin-bedded aphanitic. basal contact irregular.

$31 \ldots$ 1. 2 Chert: hard, dark-gray $(N 3)$ to mediumgray $(N 5)$, one bed; finely brecciated.

Fault, N. $20^{\circ}$ W., $60^{\circ}$ W.; beds not correlated across fault.

To-24_.. 1.2 Chert: hard, light-brownish-gray (10YR $5 / 1)$, thin-bedded; basal contact gradational. 
TABLE 17.-Measured section and analyses of Permian rocks in Newman Brothers trench, Montana, lot 1398-Continued

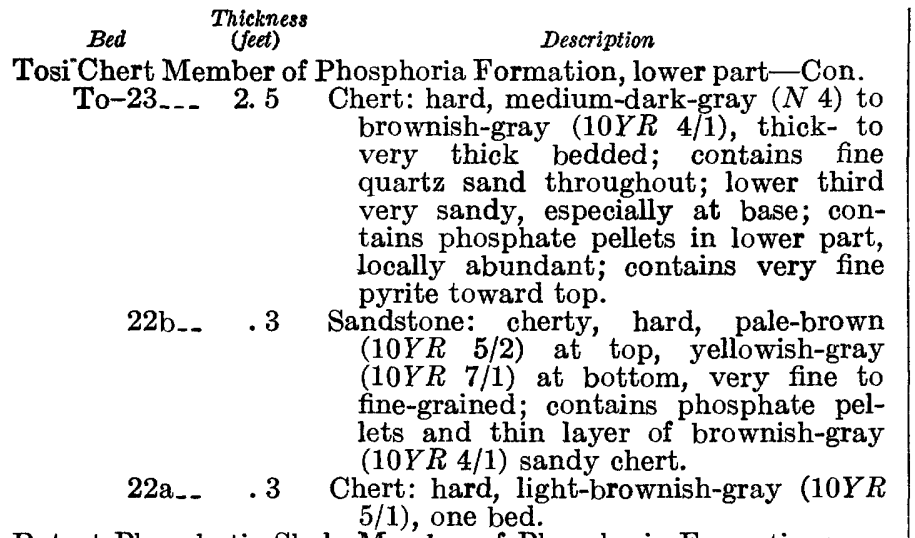

Retort Phosphatic Shale Member of Phosphoria Formation:

Rt-21c_- .5 Mudstone: cherty, hard, pale-brown $(2.5 Y 5 / 2)$; contains lenses of darkgray $(N 3)$ chert 2-3 mm thick.

$21 \mathrm{~b}$-. . 4 Carbonate rock: hard, brownish-gray $(10 Y R 5 / 1)$, aphanitic; one bed

21a.- . 1 Mudstone: hard, light-brownish-gray $(10 Y R 6 / 1)$, one bed; contains small dark-gray $(N 3)$ chert lenses.

20... . 55 Sandstone: phosphatic, hard, brownishgray $(10 Y R 4 / 1)$, one bed, fine-grained; phosphate is medium-pelletal; contains dark-gray $(N 3)$ nodules at base; basal contact irregular.
19.-_ .5 Mudstone: medium-hard, light-yellowish- brown (10YR 6/4), fissile to thin- bedded; basal contact irregular.
18... . 6 Carbonate rock: medium-hard, medium- dark-gray $(N 4)$, aphanitic; basal con- tact undulating.
17... 2. 5 Sandstone: phosphatic, hard, medium- gray $(N 5)$ to light-brownish-gray $(10 Y R 5 / 1)$, one bed, fine-grained; phosphate is medium-pelletal; basal contact irregular.
16c_- . 2 Phosphorite: sandy, hard, yellowish-gray (10YR 7/1), thin-bedded, medium- pelletal to nodular; soft mudstone parting at base.
16b_- . 2 Sandstone: phosphatic, hard, yellowish- gray (10YR 7/1), fine-grained; basal contact gradational.
16a_- . 2 Phosphorite: similar to Rt-16c; soft mud- stone parting at base.
15_._ 1.3 Phosphorite: hard, medium-gray ( $N$ 6) and very light gray $(N$ 8) to brownish- gray (i0YR 4/1), thin- to thick- bedded, coarse to very coarsely pel- letal and oolitic; locally sandy at top and bottom; in middle, light-brownish- gray aphanitic carbonate matrix con- tains light-gray phosphate pellets.
14... 2.1 Phosphorite: hard, medium-light-gray $(N$ 6) to light-brownish-gray (10YR $6 / 1$ ), thin- to thick-bedded, coarsely to very coarsely oolitic; two dark-gray $(N 3)$ aphanitic layers above middle and irregular spots elsewhere contain sparse oolites; basal contact grada- tional.
13... .6 Phosphorite: cherty, hard, medium-gray $(N 5)$, one bed, medium- to coarse- pelletal and oolitic; contains fine sand.

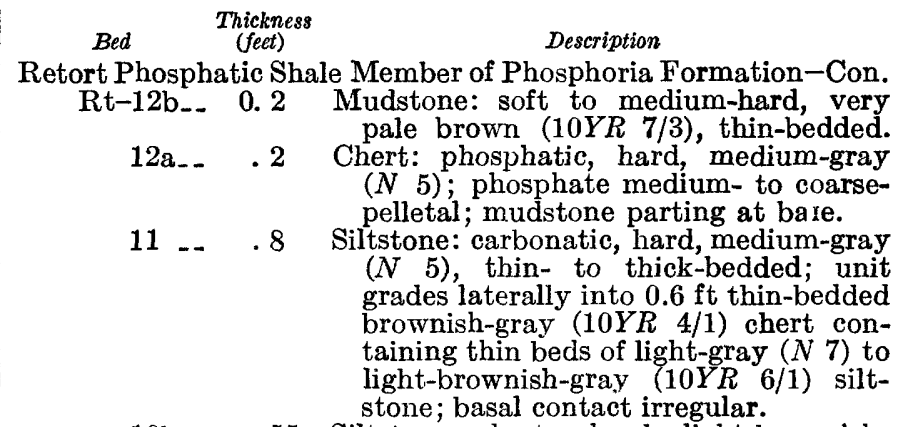

10b_ .55 Siltstone: cherty, hard, light-brownishgray $(10 Y R$ 6/1), thin-bedded; $0.05 \mathrm{ft}$
medium-hard pale-brown $(10 Y R 6 / 2)$

sandy mudstone at base.
10a_- .45 Chert: silty, hard, brownish-gray (10YR 4/1), thin-bedded.

9.... .6 Chert: hard, medium-dark-gray ( $N$ 4), thin-bedded; 0.05 -ft beds of mediumhard, light-gray $(N 7)$ to medium-gray $(N$ 5) fissile mudstone at top, middle, and base; top mudstone contains phosphate; basal contact irregular.

8.... . 3 Phosphorite: sandy, hard, medium-gray $\left(\begin{array}{l}N \\ 5\end{array}\right)$, one bed, medium-pelletal and oolitic; sand fine, more abundant downward; basal contact gradational and irregular.

7...- . 2 Sandstone: phosphatic, hard, mediumdark-gray $(N 4)$, fine-grained; phosphate less abundant downward, medium-pelletal and oolitic at top, pelletal to aphanitic below.

Lower tongue of Shedhorn Sandstone:

LS-6_-_ 1. 6 Sandstone: quartzitic, hard, mediumlight-gray $(N 6)$, fine-grained; contains

medium-pelletal phosphate.
5.... . . 7 Sandstone: conglomeratic, hard, mediumlight-gray $(N 6)$, one bed, fine- to medium-grained; contains light-brownish-gray $(10 Y R 5 / 1)$ to yellowish-gray $(10 Y R 7 / 1)$ chert pebbles as much as $25 \mathrm{~mm}$ in diameter; contains mediumpelletal phosphate and sandy nodules; basal contact irregular.

4.... . . 8 Sandstone: conglomeratic, hard, mediumgray $(N 5)$, thick-bedded, fine- to medium-grained; contains light-gray $\left(\begin{array}{ll}N & 7\end{array}\right)$ to yellowish-gray $(10 Y R \quad 7 / 1)$ chert pebbles as much as $12 \mathrm{~mm}$ in diameter; basal contact irregular.

Tongue of Park City Formation:

PC-3 _._ 2. 7 Carbonate rock: very cherty, hard, lightgray $(N 7)$, thick-bedded, aphanitic; chert occurs as medium-dark-gray $(N 4)$ rounded nodules and sharp angu-

lar fragments; basal contact irregular.
$2 \ldots . .$. $8 / 1$ ), fine- to medium-grained; contains carbonate in matrix and in laminae; contains chert grains as much as $3 \mathbf{m m}$ in diameter; basal contact irregular.

1... . . 4 Carbonate rock: cherty, hard, very light gray ( $N$ 8), aphanitic; contains mediumgrained quartz sand; chert occurs as abundant medium-gray $(N 5)$ to lightgray ( $N$ 7) pebbles and fragments. 
PHOSPHATE DEPOSITS IN CENTRAL WESTERN MONTANA

TABLe 17.-Measured section and analyses of Permian rocles in Newman Brothers trench, Montana, lot 1398-Continued

\begin{tabular}{|c|c|c|c|c|c|c|}
\hline \multirow{2}{*}{ Bed } & \multirow{2}{*}{ Sample } & \multirow{2}{*}{$\begin{array}{c}\text { Thickness } \\
\text { (feet) }\end{array}$} & \multicolumn{2}{|c|}{ Chemical analyses (percent) } & \multicolumn{2}{|c|}{ Uranium content (percent) } \\
\hline & & & $\mathrm{P}_{2} \mathrm{O}_{3}$ & $\underset{\text { insoluble }}{\text { Acid }}$ & $\mathrm{eU}$ & $\mathrm{U}$ \\
\hline
\end{tabular}

TABLE 18.-Measured section and analyses of Permian rocks in Jack Pine mine, Montana, lot 1400

[Section measured and described by R. W. Swanson, July 1954, about 90 feet from portal in Jack Pine mine, a quarter of a mile north cf Trout Creek in SW1/4SW14 sec. 35 T. 11 N., R. 7 W. Locality is on southwest limb of Dog Creek syncline; beds strike N. $45^{\circ}$ W. and dip $45^{\circ}$ NE. Samples analyzed for P2O $\mathrm{O}_{5}$ and acid insoluble by U.S. Bur Mines and for organic matter and uranium by U.S. Geol. Survey]

Thickness
(feet)

Description

Retort Phosphatic Shale Member of Phosphoria Formation, top not exposed:

Rt-10

Sandstone: phosphatic, hard, mediumdark-gray $(N$ 4) to light-brownishgray (10YR 6/1), fine-grained; phosphate occurs as medium to very coarse pellets; basal contact irregular. Mudstone: soft, moderate-brown $(5 Y R$
$4 / 4)$ to pale-brown $(10 Y R 5 / 3)$ and light-yellowish-brown $(10 Y R \quad 6 / 4)$, fissile to thin-bedded; contains laminae of pelletal phosphate.

8b_.. 6 Sandstone: phosphatic, hard, brownishgray $(10 Y R 4 / 1)$, very thin- to thickbedded, fine-grained; contains scattered black phosphate nodules.

8a_-. . 1 Mudstone: phosphatic, soft, light-yellowish-brown $(10 Y R$ 6/4); phosphate coarsely oolitic.

7... 2. 0 Phosphorite: sandy, hard, dark-gray $(N 3)$ to medium-dark-gray $(N 4)$, thick-bedded, medium- to coarsely pelletal; sand fine, more abundant near top; soft mudstone parting at base.

6.... 2.5 Phosphorite: hard, medium-dark-gray $(N 4)$ to medium-gray $(N 5)$, thinto very thick bedded, medium- to very coarsely pelletal and oolitic, basal $0.35 \mathrm{ft}$ nodular and very sandy (fine-grained); contains numerous shell

$$
\text { Bed Thickness }
$$

Description

Retort Phosphatic Shale Member of Phosphoria Formation, top not exposed-Continued

Phosphorite-Continued fragments and medium-dark-gray dull aphanitic phosphate; basal contact gradational.

Rt-5b_-_ . 2 Phosphorite: sandy, hard, medium-gray $(N 5)$ to dark-gray $(N 3)$, mediumpelletal; sand, fine-grained; basal contact gradational.

5a_-_ : 9 Sandstone: hard, light-yellowish-brown (10YR 6/4), fine-grained; slightly phosphatic; basal contact gradational.

Lower tongue of Shedhorn Sandstone, base not exposed:

LS-4_... 2.8 Sandstone: hard, light-brownish-gray $(10 Y R 5 / 1)$ to pale-brown (10YR 6/2), massive, fine-grained; locally quartzitic but much very porous; basal contact sharply gradational.

3... 1.0 Sandstone: conglomeratic, hard, lightbrownish-gray (10YR 6/1) to yellowishgray $(10 Y R 7 / 1)$, one bed, fine-grained; contains chert and some quartzite pebbles as much as $25 \mathrm{~mm}$ in diameter, mostly white to light gray.

2.... 5 Sandstone: soft to medium-hard, palebrown (10YR 6/2), fine-grained; soft sandy clay (gouge?) parting at base.

1...- : 8 Sandstone: soft to medium-hard, yellowish-gray $(10 Y R 8 / 1)$, one bed, finegrained.

\begin{tabular}{|c|c|c|c|c|c|c|c|}
\hline \multirow{2}{*}{ Bed } & \multirow{2}{*}{ Sample } & \multirow{2}{*}{$\begin{array}{l}\text { Thickness } \\
\text { (feet) }\end{array}$} & \multirow[b]{2}{*}{$\mathrm{P}_{2} \mathrm{O}_{3}$} & \multicolumn{2}{|c|}{$\begin{array}{c}\text { Chemical analyses } \\
\text { (percent) }\end{array}$} & \multicolumn{2}{|c|}{$\underset{\text { (percent) }}{\text { Uranium content }}$} \\
\hline & & & & $\begin{array}{c}\text { Acid } \\
\text { insoluble }\end{array}$ & $\begin{array}{l}\text { Organic } \\
\text { matter }\end{array}$ & $\theta U$ & $\mathbf{U}$ \\
\hline $\begin{array}{r}\text { Rt-9. } \\
8 . \\
7- \\
6 . \\
5 .\end{array}$ & $\begin{array}{l}\text { 7508-RWS } \\
\text { 7507-RWS } \\
\text { 7506-RWS } \\
\text { 7505-RWS } \\
\text { 7504-RWS }\end{array}$ & $\begin{array}{l}0.7 \\
.7 \\
2.0 \\
2.5 \\
1.1\end{array}$ & $\begin{array}{r}\text { 7. } 1 \\
14.4 \\
24.5 \\
36.8 \\
9.55\end{array}$ & $\begin{array}{r}65.7 \\
58.2 \\
36.0 \\
6.5 \\
72.7\end{array}$ & $\begin{array}{r}0.55 \\
.38 \\
.26 \\
.20 \\
.20\end{array}$ & $\begin{array}{r}0.004 \\
.004 \\
.005 \\
.011 \\
.002\end{array}$ & $\begin{array}{r}0.002 \\
.004 \\
.006 \\
.011 \\
.003\end{array}$ \\
\hline
\end{tabular}


TABLE 19.-Measured section and analyses of Retort Phosphatic Shale Member of Phosphoria Formation in Senecal incline, Montana, lot 1401

[Section measured by R. W. Swanson, July 1954, about 75 feet from portal of 125-fcot incline on property of Kathryn Senecal, SW1/4NW1/4 sec. 6 , T. 9 N., R. 6 W., Powell Caunty Mont. Locality is at faulted south end of Elliston anticline; beds strike N. $25^{\circ}$ E. and dip $15^{\circ} \mathrm{NW}$. Samples analyzed for $\mathrm{P}_{2} \mathrm{O}_{5}$ and acid insoluble by $U$.S. Bur. Mines and for uranium by U.S. Geol. Survey]

Bed Thickness

Retort Phosphatic Shale Member of Phosphoria Formation, top and bottom not exposed:

Rt-8_-_ 0.7 Mudstone: soft to medium-hard, weakyellowish-orange $(2.5 Y 8 / 4)$ to weakorange $(7.5 Y R \quad 7 / 6)$, fissile to thinbedded; slightly carbonatic.

7...- . 4 Siltstone: hard, brownish-gray (10YR 4/1), weakly laminated; slightly carbonatic.

6...- 1.0 Phosphorite: very sandy, hard, lightbrownish-gray $(10 Y R 5 / 1)$, thin- to thick-bedded, medium- to coarsely pelletal and oolitic; nodular in top 0.1 $\mathrm{ft}$ and bottom $0.2 \mathrm{ft}$, nodules (as much as $40 \mathrm{~mm}$ ) medium-dark-gray $\left(\begin{array}{ll}N & 4\end{array}\right)$; oolites light-gray $(N \quad 7)$; sand fine, pale-brown (10YR 6/2); basal contact irregular.

5...- 1. 0 Phosphorite: soft to hard, light-gray $(N 7)$ (light-gray to white pellets and oolites in medium-dark-gray $\left(\begin{array}{ll}N & 4\end{array}\right)$ aphanitic matrix), thick-bedded, medium- to coarsely pelletal and oolitic; nodular (as much as $10 \mathrm{~mm}$ ) near top; contains local masses of finegrained sandstone and minor quartz sand throughout; $0.05-\mathrm{ft}$ phosphatic mudstone at base.

\begin{tabular}{|c|c|c|}
\hline \multirow{2}{*}{\multicolumn{3}{|c|}{$\begin{array}{l}\text { Bed } \begin{array}{c}\text { Thickness } \\
(\text { feet })\end{array} \\
\text { Retort Phosphatic Shale Member of Phosphoria Formation, top } \\
\text { and bottom not exposed-Continued }\end{array}$}} \\
\hline & & \\
\hline Rt-4 & 1. 1 & $\begin{array}{l}\text { Phosphorite: soft and friable to medium- } \\
\text { hard, medium-light-gray }(N \text { 6), thin- } \\
\text { bedded, medium- to very coarsely } \\
\text { oolitic; light-gray }(N \quad 7) \text { to white } \\
\text { oolites in medium-light-gray to } \\
\text { medium-dark-gray }(N \quad 4) \text { aphanitic } \\
\text { matrix. }\end{array}$ \\
\hline $3 \ldots$ & .5 & $\begin{array}{l}\text { Phosphorite: hard, medium-gray }(N 5) \text { to } \\
\text { brownish-gray ( } 10 Y R \text { 4/1), one bed, } \\
\text { medium- to very coarsely oolitic; light- } \\
\text { gray }(N 7) \text { oolites in medium-light- } \\
\text { gray }(N 6) \text { to medium-dark-gray }(N 4) \\
\text { aphanitic matrix; nodular in basal } \\
0.1 \mathrm{ft} \text {; contains quartz sand. }\end{array}$ \\
\hline $2 b_{---}$ & .45 & $\begin{array}{l}\text { Limestone: muddy, hard, light-yellowish- } \\
\text { brown (10YR 6/4) to dark-yellow } \\
(2.5 Y \text { 6/8) and weak-orange-yellow } \\
(2.5 Y 7 / 4) \text {, one bed, aphanitic. }\end{array}$ \\
\hline $2 a_{-}$ & .15 & Chert and mudstone: hard, light- \\
\hline 1. & 3. 0 & $\begin{array}{l}\text { Chert: hard, medium-dark-gray }(N 4) \text {, } \\
\text { thin-bedded; contains soft to medium- } \\
\text { hard yellowish-gray }(10 Y R \text { T/1) fissile } \\
\text { mudstone interbeds at } 0.3,0.6,0.8,1.1 \text {, } \\
2.1 \text {, and } 2.5 \mathrm{ft} \text { above base. }\end{array}$ \\
\hline
\end{tabular}

\begin{tabular}{|c|c|c|c|c|c|c|}
\hline \multirow{2}{*}{ Bed } & \multirow{2}{*}{ Sample } & \multirow{2}{*}{$\begin{array}{c}\text { Thickness } \\
\text { (feet) }\end{array}$} & \multicolumn{2}{|c|}{ Chemical analyses (percent) } & \multicolumn{2}{|c|}{ Uranium content (percent) } \\
\hline & & & $\overrightarrow{\mathrm{P}_{2} \mathrm{O}_{5}}$ & Acid insoluble & $\mathrm{eU}$ & $\mathrm{U}$ \\
\hline $\begin{array}{r}\text { Rt-6. } \\
5 \\
4 \\
3 \\
2 \\
2\end{array}$ & $\begin{array}{l}\text { 7513-RWS } \\
\text { 7512-RWS } \\
\text { 7511-RWS } \\
\text { 7510-RWS } \\
\text { 7509-RWS }\end{array}$ & $\begin{array}{l}1.0 \\
1.0 \\
1.1 \\
.5 \\
.6\end{array}$ & $\begin{aligned} 18.9 \\
29.5 \\
36.0 \\
29.5 \\
1.6\end{aligned}$ & $\begin{array}{l}48.0 \\
21.9 \\
7.67 \\
21.9 \\
52.8\end{array}$ & $\begin{array}{r}0.004 \\
.006 \\
.011 \\
.009 \\
<.001\end{array}$ & $\begin{array}{l}0.004 \\
.007 \\
.012 \\
.009 \\
.001\end{array}$ \\
\hline
\end{tabular}

top of the lower tongue of the Shedhorn Sandstone, much as it does in the Garnet Range.

The upper part of the Retort Member contains sandy phosphorite and phosphatic sandstone, thus corresponding to the upper sandy zone of the districts to the west and southwest, and it also contains some thin beds of variably phosphatic mudstone, chert, and carbonate rock. The sandy zone seems to be little more than 1 foot thick at some localities but is almost 6 feet thick at Elliston (lot 1398). Most of the sandstone in it contains more than 10 percent $\mathrm{P}_{2} \mathrm{O}_{5}$.

The strata above the Retort Member consist predominantly of thin-bedded chert characteristic of the Tosi Member, but they also include some beds of fine-grained sandstone. A thickness of nearly 25 feet of these strata was measured east of Elliston (lot 1397) ; the upper part is covered there, so the total thickness must be at least a little greater. The Tosi Member, however, including tongues of the upper member of the Shedhorn Sandstone, is probably not much more than 30 feet thick anywhere in this district.
The Permian rocks in the Elliston district are involved in the large Elliston anticline (pl. 34C) and the Dog Creek syncline, both of which strike about N. $45^{\circ}$ W. and plunge southeast at low to moderate angles (Stone and Bonine, 1914, p. 9 ; Stone, 1952, pl. 1). At the edge of the Avon Valley, nearly all of the rocks on the southwest limb of the Elliston anticline are covered by downfaulted younger rocks. On the northeast limb of the Dog Creek syncline, Permian rocks are exposed for a few miles from the north end, but farther southeast they are covered by volcanic rocks. On the limb common to the two folds, the strata dip moderately to very steeply and are locally overturned. Small bodies of andesitic rocks have been intruded into the sedimentary formations near the middle of this limb. Some of these are sill-like and others irregular, and the sediments in this area are generally metamorphosed to hornfels.

Near the south end of the Elliston anticline, in the general vicinity of Elliston and the Little Blackfoot River, the strata are displaced by numerous faults, many of small to intermediate throw, which are in two 
sets that strike northward and eastward, respectively. The northward-striking faults are more or less parallel to the strike of the beds, but only a part of the geology of this area has been mapped in detail so the relations of the faults to the folds is somewhat uncertain.

The strata south of the east-trending fault zone belong to the west limb of an anticline. The Permian rocks in this limb are nearly in line with those forming the east limb of the Elliston anticline north of the fault zone, which suggests that there has been a major lateral displacement on that zone. In this area, however, the rocks are not well exposed, and the geology has not been mapped completely enough to show the direction or amount of any lateral movement that may have occurred. If this fault zone is part of the Lewis and Clark line, or if it is related to westward push by the Boulder batholith, the movement would apparently be right lateral. But if it is part of a later tear bounding the north side of the block beneath the Philipsburg thrust, which moved eastward late in the Laramide orogeny, the movement is left lateral, in which case the shear must have crossed the Lewis and Clark line and invaded the block north of that line.

Most of the north-trending faults have the upthrow on the west and result in repetition of the Permian outcrops (Stone and Bonine, 1914; Stone, 1952). Immediately east of Elliston, the north-trending structural features have been identified on both sides of the Little Blackfoot Valley (Stone, 1952), but within a very short distance to the south they are mostly covered by Tertiary volcanic rocks (Ross and others, 1955).

The small bodies of intrusive igneous rock in the Dog Creek syncline are probably related to the Boulder batholith, the west border of which is only a few miles east and southeast of Elliston. Near them, the invaded sedimentary rocks are locally metamorphosed to hornfels, and they are doubtless more strongly metamorphosed close to the batholith. Intrusion appears to have been later than most, if not all, of the folding and faulting.

In the Elliston district, as in the Garrison district, most of the phosphate occurs in a single zone of phosphorite. This zone is less than $21 / 2$ feet thick in some places (pl. 32) and as much as $71 / 2$ feet in other places nearby (Stone and Bonine, 1914, p. 382). It also varies widely in quality; some beds contain too little phosphate to be suitable even for furnace feed, and other beds almost thick enough to mine by themselves contain as much as 35 percent $\mathrm{P}_{2} \mathrm{O}_{5}$ (pl. 32 ).

This irregularity in distribution of phosphate is not surprising, for the Elliston district is near the landward margin of an area in which strata of geosynclinal and platform facies intertongue, so individual beds and sequences of beds of any lithology are likely to pinch or swell abruptly, or even to be absent locally. Thickness and quality may remain uniform over areas large enough to be mined, but they are both more apt to vary widely within a mining property in this district than in most other parts of the western phosphate field. These variations of thickness and grade are in striking contrast to their general uniformity in the eastern part of the Garrison district.

A layer of very high grade phosphate appears to extend through the greater part of the Elliston district, but nowhere is it thick enough to mine by itself. Furnace- to near acid-grade phosphate rock commonly occurs both above and below this layer, and by including all or part of adjoining layers, a thickness of 3 feet or more containing 31 percent $\mathrm{P}_{2} \mathrm{O}_{5}$ can be defined in several places. It is rarely feasible, however, to mine only part of a layer, so there are few places in this district in which acid-grade phosphate rock 3 feet or more thick coulk be found. In many places, however, acidgrade plant feed could be obtained by slightly improving the grade through beneficiation.

Furnace-grade phosphate rock 3 feet or more thick was found at most of the localities sampled by Stone and Bonine (1914) and by the writer. At some places, that thickness could be obtained only by including at the base or top of the zone a bed that contains less than 24 percent $\mathrm{P}_{2} \mathrm{O}_{5}$, but even then the net grade for 3 feet would usually be several percent above cutoff. Acidinsoluble matter, chiefly quartz, is the only material other than apatite that is present in significant quantity in most of the phosphorite of this district; both carbonate and organic matter are low, so the phospate rock should make a good furnace charge. Except for uranium, the content of minor elements that might affect quality is not known.

The sandy zone immediately overlying the main phosphorite bed ranges from 0.7 to 3.1 feet in thickness and contains 13 to 19 percent $\mathrm{P}_{2} \mathrm{O}_{5}$. At only one locality (lot 1401) does it contain enough $\mathrm{P}_{2} \mathrm{O}_{5}$ (18 percent or more) for it to be considered for resource estimation. The main phosphorite bed, however, is so rich in this area that some silica flux would have to be added to make it usable as a furnace charge. Mining of material from the upper sandy zone with the main phosphorite bed would satisfy this need and also significantly increase the total reserve of phosphate.

In parts of the Elliston district, the layer immediately below or above the phosphate zone consists of soft lowgrade shale that would make a false footwall or hanging wall, with consequent dilution in mining, for although the shaly layers are generally less than 1 foot thick, they could materially reduce the average grade. 
They are likely to be especially soft within a few hundred feet of any outcrop from which weathering has removed cementing material or otherwise disintegrated the rock, and also in places where folding has caused bedding-plane slippage. In either case, the fresher rock at depth may present fewer dilution problems.

The phosphate in the Elliston district must be slightly metamorphosed near the small intrusive bodies in the middle part of the east limb of the Elliston anticline and strongly metamorphosed near the Boulder batholith. The latter fact was allowed for in estimating the phosphate resources of this area (fig. 207 and table 20), but the boundary of the batholith is largely covered so the allowance could be only approximate. Because of the very limited information on the bedrock geology of the area south of the river near Elliston, no phosphate resources are estimated for that area, though much of it is probably underlain by Permian rocks.

The phosphate in the Elliston district has been prospected at many places, from both surface and underground exposures. A small tonnage has been produced from each of several underground exposures. Much of the exploration and production was before World War II, when acid-grade rock was required. The potential for furnace-grade rock from this district seems greater, however, particularly if beneficiation can be utilized.

\section{HELENA-THREE FORKS AREA}

East of the Boulder batholith is a large area that contains Permian rocks in a variety of open to tight fold and fault structures (pl. 30; and Swanson, 1970, fig. 169). The southern part of the area is near the Jefferson and Gallatin Rivers, and the northern part is near Helena at the north end of the batholith. The north end is separated from the Elliston district by the northernmost part of the batholith. The area extends eastward about 15 miles east of the Missouri River. The area described here is expanded beyond the borders of plate 30 to include the adjacent area in southwest Montana that lies within 30 miles southwest and northeast of Three Forks. The Permian rocks are continuous across the boundary between the two areas and are generally similar, so the entire area is treated as a unit in description and evaluation of the phosphate deposits.

Altitudes in the area range from 3,650 feet on the Missouri River at the east to 9,414 feet on Crow Peak, near the edge of the batholith (NW cor. T. 6 N., R. 2 W.). The floors of the basins on the east and north are generally below 4,000 feet, but the altitudes in Boulder Valley reach a maximum of about 5,000 feet. Permian rocks crop out at an altitude of more than 8,000 feet on the southwest side of Crow Peak, but most of their outcrops are below 5,000 feet.

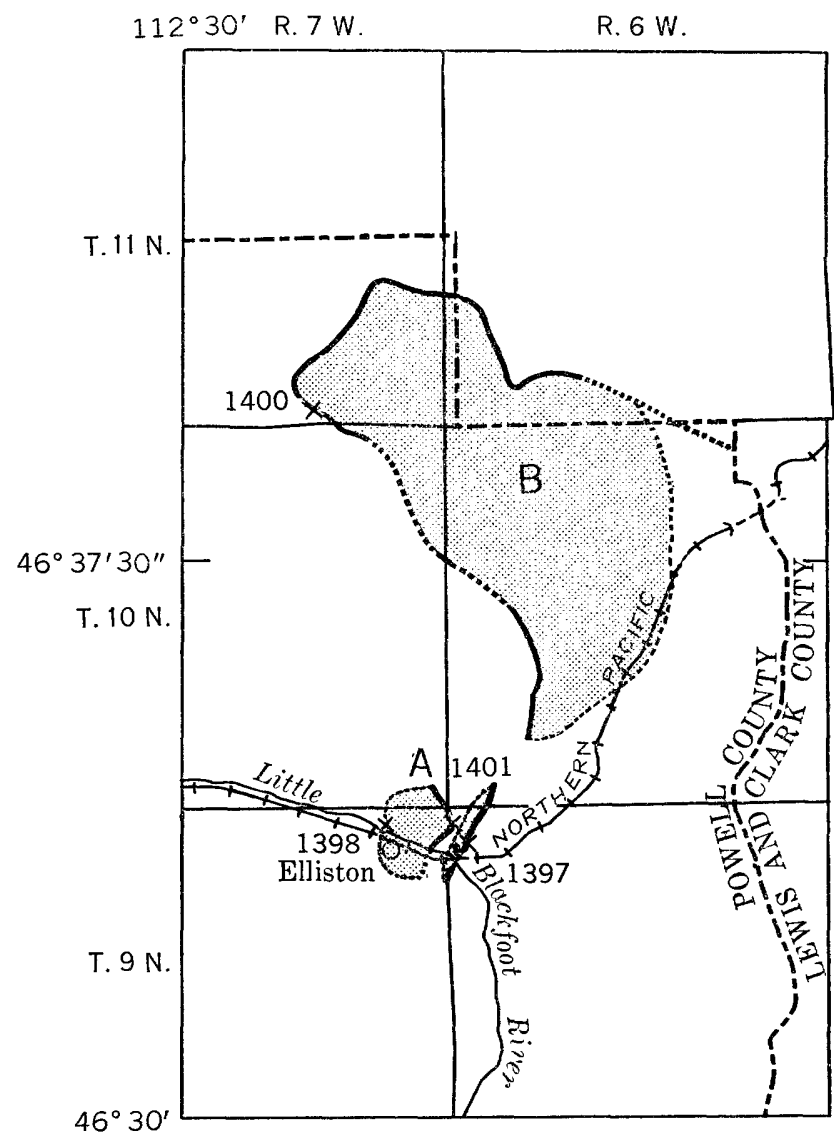

\section{EXPLANATION}

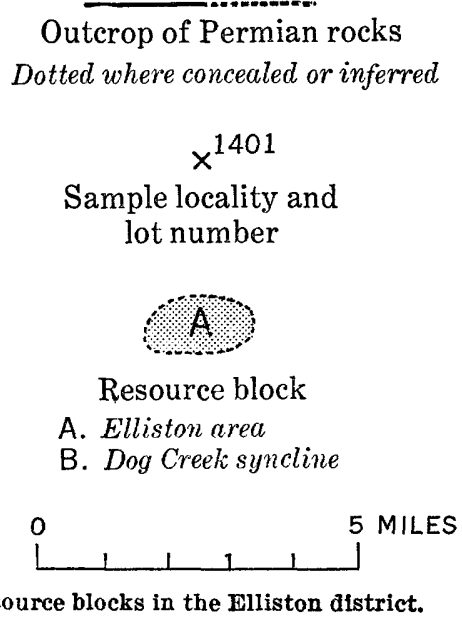

The early geologic mapping by Knopf (1913, pls. 1 and 7$)$ in the Helena region, by Weed $(1901$, pl. 45) and Stone (1911, pl. 3) in the Elkhorn Moutains west of Radersburg, by Haynes (1916) near Lombard (16 miles up river from Townsend), and by Peale (1896) south of the 46th parallel established the general distribution of rock units and the basic geologic structure. In all these reports, however, the Permian strata were included with 
the Quadrant Quarzite and not separately identified. R. W. Stone (Pardee, 1913, p. 285) discovered rock phosphate near the Jefferson River in 1911, and Condit, Finch, and Pardee (1928, p. 176-181) first described the Permian rocks in the Three Forks-Jefferson CanyonRadersburg area. More recent mapping by Smedes (1962) southeast of Helena; by Klepper, Weeks, and Ruppel (1957), Freeman, Ruppel, and Klepper (1958), and R. A. Weeks, M. R. Klepper, V. L. Freeman, and E. T. Ruppel (unpub. data) on the east side of the batholith; by Klemme (1949) and by Skipp and Peterson (1965) east of the Missouri River; by Robinson (1963) near Three Forks; and by Alexander (1955) in the Jefferson Canyon area show the distribution of Per- mian rocks in most of the Helena-Three Forks area in considerable detail.

In the western part of the Helena-Three Forks area, the Permian strata are more than 100 feet thick at most localities (table 21; Cressman and Swanson, 1964, lots 1356, 1357, 1364, and 1365; Klepper and others, 1957, p. 22) and 93 feet thick near Helena (Smedes, 1966, p. 8). Eastward they thin fairly abruptly and terminate within 15 miles east of the Missouri River (Klemme, 1949), due to both onlap and pre-Jurassic erosion (Cressman and Swanson, 1964, fig. 94). Jurassic rocks overlie the Permian in this entire area so it is not possible to define the original thickness of Permian strata; the contact is generally concordant.

TABLE 20.-Phosphate resources in the Retort Phosphatic Shale Member of the Phosphoria Formation, Elliston district, Montana

[Phosphate resources given in millions of short tons]

\begin{tabular}{|c|c|c|c|c|c|c|c|c|c|c|c|}
\hline \multirow{3}{*}{ Resource block } & \multicolumn{3}{|c|}{$\begin{array}{l}\text { Area (millions of sq ft in plane } \\
\text { of bedding) }\end{array}$} & \multicolumn{3}{|c|}{ Basic Retort Member Data } & \multicolumn{5}{|c|}{ Rock containing $>31$ percent $\mathrm{P}_{2} \mathrm{O}_{3}$} \\
\hline & \multirow[b]{2}{*}{$\begin{array}{l}\text { Above } \\
\text { entry } \\
\text { level }\end{array}$} & \multirow{2}{*}{$\begin{array}{l}\text { First } \\
100 \mathrm{ft} \\
\text { below } \\
\text { entry } \\
\text { level }\end{array}$} & \multirow{2}{*}{$\begin{array}{l}\text { Total } \\
\text { block }\end{array}$} & \multirow[b]{2}{*}{$\begin{array}{l}\text { Average } \\
\text { thickness } \\
\text { (ft) }\end{array}$} & \multirow{2}{*}{$\begin{array}{c}\text { Average } \\
\text { grade } \\
\text { (percent } \\
\mathrm{P}_{2} \mathrm{O}_{5} \text { ) }\end{array}$} & \multirow{2}{*}{$\begin{array}{l}\text { Total } \\
\mathrm{P}_{2} \mathrm{O}_{5}\end{array}$} & \multirow[b]{2}{*}{$\begin{array}{c}\text { Thick- } \\
\text { ness } \\
(\mathrm{ft})\end{array}$} & \multirow[b]{2}{*}{$\begin{array}{c}\text { Grade } \\
\text { (percent } \\
\mathrm{P}_{2} \mathrm{O}_{5} \text { ) }\end{array}$} & \multicolumn{3}{|c|}{ Tonnage } \\
\hline & & & & & & & & & $\begin{array}{l}\text { Above } \\
\text { entry } \\
\text { level }\end{array}$ & $\begin{array}{l}\text { First 100 } \\
\text { ft below } \\
\text { entry level }\end{array}$ & $\begin{array}{l}\text { Total } \\
\text { block }\end{array}$ \\
\hline $\begin{array}{l}\text { Elliston area } \\
\text { Dog Creek syncline }\end{array}$ & $\begin{array}{r}9.4 \\
48.9\end{array}$ & $\begin{array}{l}1.5 \\
9.5\end{array}$ & $\begin{array}{r}27 \\
654\end{array}$ & $\begin{array}{r}11.3 \\
7.8\end{array}$ & $\begin{array}{l}15.8 \\
19.7\end{array}$ & $\begin{array}{r}4 \\
85\end{array}$ & 4.4 & 31.0 & 7.0 & 0.8 & 50 \\
\hline Totals and averages. & 59.3 & 11.0 & 681 & 7.9 & 19.5 & 89 & 4.4 & 31.0 & 7.0 & 0.8 & 50 \\
\hline
\end{tabular}

Rock containing $>24$ percent $\mathrm{P}_{2} \mathrm{O}_{5}$

Rock containing $>18$ percent $\mathrm{P}_{2} \mathrm{O}_{5}$

\begin{tabular}{|c|c|c|c|c|c|c|c|c|c|c|}
\hline \multirow[t]{2}{*}{ Resource block } & \multirow[b]{2}{*}{$\underset{\text { (ft) }}{\text { Thickness }}$} & \multirow[b]{2}{*}{$\begin{array}{l}\text { Grade } \\
\text { (percent } \\
\left.\mathrm{P}_{2} \mathrm{O}_{5}\right)\end{array}$} & \multicolumn{3}{|c|}{ Tonnage } & \multirow[b]{2}{*}{$\begin{array}{l}\text { Thickness } \\
\text { (ft) }\end{array}$} & \multirow[b]{2}{*}{$\begin{array}{l}\text { Grade } \\
\text { (percent } \\
\mathrm{P}_{2} \mathrm{O}_{5} \text { ) }\end{array}$} & \multicolumn{2}{|c|}{ Tonnage } & \multirow[b]{2}{*}{$\begin{array}{l}\text { Total } \\
\text { block }\end{array}$} \\
\hline & & & $\begin{array}{l}\text { Above } \\
\text { entry } \\
\text { level }\end{array}$ & $\begin{array}{l}\text { First } 100 \\
\text { ft below } \\
\text { entry level }\end{array}$ & $\begin{array}{l}\text { Total } \\
\text { block }\end{array}$ & & & $\begin{array}{l}\text { Above } \\
\text { entry } \\
\text { level }\end{array}$ & $\begin{array}{l}\text { First } 100 \\
\text { ft below } \\
\text { entry level }\end{array}$ & \\
\hline $\begin{array}{l}\text { Elliston area... } \\
\text { Dog Creek syncline }\end{array}$ & $\begin{array}{l}3.4 \\
3.7\end{array}$ & $\begin{array}{l}27.5 \\
29.6\end{array}$ & $\begin{array}{r}3.0 \\
15.0\end{array}$ & $\begin{array}{l}0.4 \\
3.0\end{array}$ & $\begin{array}{r}8 \\
200\end{array}$ & $\begin{array}{l}7.0 \\
3.7\end{array}$ & $\begin{array}{l}23.0 \\
29.7\end{array}$ & $\begin{array}{r}4.0 \\
15.0\end{array}$ & $\begin{array}{l}0.7 \\
3.0\end{array}$ & $\begin{array}{r}15 \\
200 \\
\end{array}$ \\
\hline Totals and averages. . . . . . . . . . & 3.7 & 29.5 & 18.0 & 3.4 & 208 & 3.8 & 29.4 & 19.0 & 3.7 & 215 \\
\hline
\end{tabular}

TABLE 21.-Measured section and analyses of Permian rocks northwest of Wheatland School, Montana, lot 1384

[Section measured and described by E. T. Ruppel and D. E. Brambilla, June 1952, about 3.5 miles northwest of Wheatland School in SW1/4SE1/4 sec. 7, T. 3 N., R. 1 W., Jefferson County, Mont. Samples analyzed for $\mathrm{P}_{2} \mathrm{O}_{3}$ and acid insoluble by U.S. Bur. Mines and for uranium by U.S. Geol. Surveyl

\section{Bed Thickness (feet) Description}

Upper Jurassic Swift Sandstone, basal bed:

J-48 - 3. 7 Conglomerate.

Tosi Chert Member of Phosphoria Formation and upper tongue of Shedhorn Sandstone, interbedded, upper part only:

To-47 3.8 Chert.

US-46.-- 1.0 Quartzite.

To-45..- 2.0 Chert.

US-44_- 1.0 Quartzite.

USTo-43 - 10.8 Quartzite and chert.

$?-42=17.0$ Covered.

?-41 - 14.3 Covered; contains phosphorite float.

Fault. Beds $43-47$ above probably correlate with upper part of sequence below.

$?-21 \ldots$ 2. 8 Covered.

US-20..- 6.4 Sandstone: muddy, medium-grained,

light-brown.

To-19_.- 9.8 Chert: yellowish-brown, blocky and chippy.

US-18_.. . 8 Quartzite or chert: very fine grained

17.- 8.1 Sandstone: muddy, medium-grained, light-brown.

?-16_- 45. 0 Covered.

To-15_.. 2. 0 Chert: brownish-gray.

\section{Bed Thickness}

Description

Retort Phosphatic Shale and Tosi Chert Members of Phosphoria Formation, interbedded:

Rt-14... 2. 7 Phosphorite: muddy, oolitic, dark-gray. 13_- .6 Mudstone: phosphatic, carbonatic(?).

12 ..- 2 Phosphorite: muddy, oolitic, dark-gray.

11_- .5 Phosphorite: muddy, oolitic, dark-gray.

To-10..- 1. 0 Chert.

Rt-9... 13. 2 Chert: thinly laminated, yellowish-brown, platy to blocky.

To-7.-.- $\quad .6$ Chert: phosphatic. platy to blocky.

Rt-6.... 1.2 Sandstone, phosphatic, and interbedded

?-5 3.7 Covered.

Lower tongue of Shedhorn Sandstone, upper part:

LS-4_... 1. 3 Quartzite: light-brown, vitreous.

?-3.-- 3. 7 Covered.

LS-2_... . 6 Quartzite: white to yellow-brown, vitreous.

?-1_.._ 15. $0 \pm$ Covered. Contact with Quadrant Quartzite not exposed. 
TABLE 21.-Measured section and analyses of Permian rocks northwest of Wheatland School, Montana, lot 1384-Continued

\begin{tabular}{|c|c|c|c|c|c|c|}
\hline \multirow{2}{*}{ Bed } & \multirow{2}{*}{ Sample } & \multirow{2}{*}{$\begin{array}{c}\text { Thickness } \\
\text { (feet) }\end{array}$} & \multicolumn{2}{|c|}{ Chemical analyses (percent) } & \multicolumn{2}{|c|}{ Uranium content (percent) } \\
\hline & & & $\widetilde{\mathrm{P}_{2} \mathrm{O}_{5}}$ & Acid insoluble & $\mathrm{eU}$ & $\vec{U}$ \\
\hline $\begin{array}{r}\text { Rt-14_- } \\
13_{-} \\
12_{-} \\
11_{-} \\
8 .-\end{array}$ & 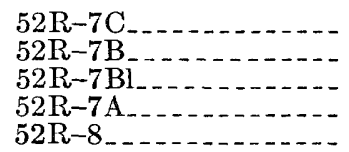 & $\begin{array}{r}2.7 \\
.6 \\
.2 \\
.5 \\
.6\end{array}$ & $\begin{array}{l}26.1 \\
12.0 \\
21.0 \\
24.9 \\
15.0\end{array}$ & $\begin{array}{l}24.4 \\
38.9 \\
20.8 \\
26.0 \\
55.1\end{array}$ & $\begin{array}{l}0.007 \\
.004 \\
.005 \\
.006 \\
.005\end{array}$ & $\begin{array}{r}0.006 \\
.004 \\
.004 \\
.005 \\
.004\end{array}$ \\
\hline
\end{tabular}

The strata are composed of chert, phosphatic shale, sandstone, and carbonate rock representing the Phosphoria, Shedhorn, and Park City Formations (Cressman and Swanson, 1964, pls. 19 and 22). The chert and phosphatic shale are generally interbedded and variably sandy and are not as dark as farther west, due in part to weathering, nor is the chert as well bedded. They dominate the section toward the southwest; northeastward the chert is nodular. Few beds of phosphorite are as thick as 1 foot (pl. 33), and they are generally separated by a similar or greater thickness of poorly phosphatic shale or chert. The phosphate is typically oolitic, and generally it is mixed with much clastic material. In the upper part of the section, the chert is interbedded with sandstone, and in the lower part, sandstone and carbonate rock, variably cherty, are interbedded. Northward, sandstone is the dominant lithology. It is mostly fine to medium grained, but some beds are pebbly, probably reflecting minor diastems, and at the east near the termination of the Permian rocks, chert- and limestone-pebble conglomerate (Klemme, 1949) reflects a shoreline or shallow-water facies. The carbonate is commonly dolomitic and silty to cherty, and it is mostly aphanitic to finely crystalline.

The Helena-Three Forks area includes more than 50 linear miles of outcrop of Permian rocks within that part covered by plate 30 and more than 180 miles in the adjacent part to the south and east (Swanson, 1970, fig. 169). At the north, these rocks crop out chiefly in T. 9 N., R. 2 W., and strike generally east. They are on the south side of what is called here the Helena anticline, which is similar to but larger than the anticlines in the Elliston and Garrison districts. Most of the Permian rock on this side of the anticline is covered by the basin-fill deposits at the south side of Prickly Pear Basin.

The Permian rocks that were on the southwest side of the anticline have been destroyed by the Boulder batholith, but Knopf (1913, pl. 1) mapped Quadrant Quartzite for nearly 2 miles at the margin of the intrusive about 6 miles west of Helena. Inasmuch as he assigned rocks now known to be Permian to the Quadrant, it is possible that Permian rocks crop out in that area.
Before intrusion, these rocks were part of the northeast limb of the Dog Creek syncline.

The Permian rocks in most of the area near Helena are so near the Boulder batholith that they are metamorphosed; they dip generally toward it, so they probably are cut off by it at relatively shallow depth.

Precambrian to Pennsylvanian strata on the short east flank of the Helena anticline crop out in the Spokane Hills. Permian strata are probably present but are concealed by deposits of Tertiary and Quaternary age (Mertie and others, 1951, pl. 1).

A limestone sequence, locally shaly, cherty, or sandy, that occurs between faults near White Gulch at the northeast side of Townsend Valley in the foothills of the Big Belt Mountains (sec. 19, T. 10 N., R. 2 E.) was tentatively assigned to the Phosphoria Formation by Mertie, Fischer, and Hobbs (1951, p. 28, pl. 1). Two partial sections, each about 55 feet thick, were measured by the writer in 1954, and the shaly beds were sampled (Swanson and others, 1956, p. 18-19); the samples contained only about 1 percent $\mathrm{P}_{2} \mathrm{O}$. Later that year these strata were judged "non-Phosphoria" by J. Steele Williams (oral commun., 1954); they may belong to the Big Snowy Group.

On the east side of the Boulder batholith, Permian rocks presumably underlie a large synclinal area in the Elkhorn Mountains south of the Helena anticline that is nearly 20 miles long in which a thick series of volcanic rocks and tuffaceous sediments of Cretaceous age crop out (Smedes, 1966, pl. 1; Klepper and others, 1957, pl. 1). Many small intrusives are present in this area. In the southern Elkhorn Mountains, the structure immediately east of the Boulder batholith is anticlinal, and Precambrian to lower Mesozoic formations are exposed. The folds include north-trending elongated domes and basins, and the strata are displaced by numerous diagonal faults, mostly of small throw. Apparently Permian rocks are not much affected by the small intrusives of the area, but undoubtedly they are metamorphosed near their termination against the batholith. Extensive cover in and near the Boulder Valley on the southwest conceals much of the Permian.

East of this anticlinal area is a syncline 6 to 8 miles or more wide and more than 30 miles long, extending 
from the latitude of Townsend (T. 7 N.) to that of Three Forks (T. 2 N.). This fold, called the Radersburg syncline, resembles the synclinal area in the northern Elkhorns in containing a thick sequence of Upper Cretaceous volcanic rocks and many hypabyssal and plutonic intrusive bodies. Permian rocks are exposed along much of its west flank, though along its east flank their exposures are limited at the north to about 7 miles of outcrop in the Limestone Hills near Townsend, and at the south to small areas whose aggregate length is only a few miles (Freeman and others, 1958). Much of the east flank has been reduced to a low level by erosion and is covered by surficial deposits.

Permian strata probably underlie the basin-fill deposits in parts of both the Townsend and Boulder valleys, but if so they may be very deeply covered.

In the Jefferson Canyon area, a few miles south of the Radersburg syncline, are many miles of outcrop of Permian rocks. This area is at the north side of the southwest Montana positive area (Swanson, 1970, fig. 173), and the rocks are complexly folded and faulted (Alexander, 1955; Barnes, 1954). Eastward, the Permian rocks are buried beneath Tertiary continental deposits.

Northeast of Three Forks, Permian rocks underlie a considerable area and crop out for many miles (Klemme, 1949; Skipp and Peterson, 1965; Swanson, 1970, fig. $169)$. In the western part of this area, particularly near the Missouri River, is a major zone of north-trending thrust and normal faults and folds, dominated by the
Lombard thrust of Haynes (1916) on which Belt rocks from the west have overriden Paleozoic and Mesozoic formations. This area is described by Robinson (1959, p. 34) as near the south end of the Disturbed Belt, "which stretches for more than 350 miles along the eastern front of the Northern Rocky Mountains." The writer believes that the Disturbed Belt connects westward from Three Forks with the structurally complex Jefferson Canyon area and thence southwestward with the southwest Montana synclinorium near Dillon.

The phosphate in almost all of the Helena-Three Forks area occurs in thin beds that are separated by barren strata (pl. 33; Swanson, 1970, pl. 26, Three Forks region). An exception is the 4-foot zone at Wheatland School (lot 1384, p. 829, beds Rt-11 to 14) which contains 23.6 percent $\mathrm{P}_{2} \mathrm{O}_{5}$. It is doubtful whether any significant tonnage of phosphate rock in a zone 3 feet thick and above cutoff grade is present in this area, and none has been estimated.

\section{SUMMARY OF PHOSPHATE RESOURCES IN GENTRAL WESTERN MONTANA}

The Permian rocks in central western Montana are estimated to contain about 600 million tons of high (acid)-grade phosphate rock, nearly 2 billion tons of intermediate (furnace)-grade phosphate rock, or more than $2 \frac{1}{2}$ billion tons of low-grade phosphate rock (table 22 ). Tonnages of higher quality rock are included in (not in addition to) the estimates of lower quality rock. No estimates were made for the area east of the Boulder

TABLE 22.-Summary of phosphate resources in the Retort Phosphatic Shale Member of the Phosphoria Formation in central western Montana

[Phosphate resources given in millions of short tons]

\begin{tabular}{|c|c|c|c|c|c|c|c|c|c|c|c|}
\hline \multirow{3}{*}{ District } & \multicolumn{3}{|c|}{$\begin{array}{l}\text { Area (millions of sq ft in plane } \\
\text { of bedding) }\end{array}$} & \multicolumn{3}{|c|}{ Basic Retort Member Data } & \multicolumn{5}{|c|}{ Rock containing $>31$ percent $\mathrm{P}_{2} \mathrm{O}_{5}$} \\
\hline & \multirow[b]{2}{*}{$\begin{array}{c}\text { Above } \\
\text { entry } \\
\text { level }\end{array}$} & \multirow{2}{*}{$\begin{array}{l}\text { First } \\
\text { 100 ft } \\
\text { below } \\
\text { entry } \\
\text { level }\end{array}$} & \multirow{2}{*}{$\begin{array}{l}\text { Total } \\
\text { block }\end{array}$} & \multirow[b]{2}{*}{$\begin{array}{c}\text { Average } \\
\text { thickness } \\
\text { (ft) }\end{array}$} & \multirow{2}{*}{$\begin{array}{l}\text { Average } \\
\text { grade } \\
\text { (percent } \\
\left(\mathrm{P}_{2} \mathrm{O}_{5}\right)\end{array}$} & \multirow{2}{*}{$\begin{array}{l}\text { Total } \\
\mathrm{P}_{2} \mathrm{O}_{5}\end{array}$} & \multirow[b]{2}{*}{$\begin{array}{c}\text { Thick- } \\
\text { ness } \\
\text { (ft) }\end{array}$} & \multirow{2}{*}{$\begin{array}{c}\text { Grade } \\
(\text { percent } \\
\left.\mathrm{P}_{2} \mathrm{O}_{5}\right)\end{array}$} & \multicolumn{3}{|c|}{ Tonnage } \\
\hline & & & & & & & & & $\begin{array}{l}\text { Above } \\
\text { entry } \\
\text { level }\end{array}$ & $\begin{array}{l}\text { First } 100 \\
\text { ft below } \\
\text { entry leval }\end{array}$ & $\begin{array}{l}\text { Total } \\
\text { block }\end{array}$ \\
\hline $\begin{array}{l}\text { Anaconda } \\
\text { Philipsburg } \\
\text { Maxville-_arson } \\
\text { Garrison } \\
\text { Elliston }\end{array}$ & $\begin{array}{r}43.4 \\
53.9 \\
168.8 \\
68.4 \\
58.3\end{array}$ & $\begin{array}{r}4.5 \\
11.1 \\
29.3 \\
11.7 \\
11.0\end{array}$ & $\begin{array}{r}154 \\
291 \\
2,549 \\
1,033 \\
681\end{array}$ & $\begin{array}{r}20.0 \\
24.0 \\
11.0 \\
8.5 \\
7.9\end{array}$ & $\begin{array}{l}18.0 \\
13.0 \\
20.5 \\
20.0 \\
19.5\end{array}$ & $\begin{array}{r}45 \\
75 \\
485 \\
145 \\
89\end{array}$ & $\begin{array}{l}3.6 \\
3.7 \\
4.4\end{array}$ & $\begin{array}{l}32.0 \\
32.3 \\
31.0\end{array}$ & $\begin{array}{r}29.0 \\
19.0 \\
7.0\end{array}$ & $\begin{array}{r}5.4 \\
3.5 \\
.8\end{array}$ & $\begin{array}{r}200 \\
350 \\
50\end{array}$ \\
\hline Totals and averages & 392.8 & 67.6 & 4,711 & 11.1 & 19.7 & 839 & 3.7 & 32.1 & 55.0 & 9.7 & 600 \\
\hline
\end{tabular}

Rock containing $>24$ percent $\mathrm{P}_{2} \mathrm{O}_{6}$

\begin{tabular}{|c|c|c|c|c|c|c|c|c|c|c|}
\hline \multirow{3}{*}{ District } & \multirow[b]{3}{*}{$\underset{\text { (ft) }}{\text { Thickness }}$} & \multirow[b]{3}{*}{$\begin{array}{c}\text { Grade } \\
\text { (percent } \\
\left.\mathrm{P}_{2} \mathrm{O}_{5}\right)\end{array}$} & \multirow{2}{*}{\multicolumn{3}{|c|}{ Tonnage }} & \multirow[b]{3}{*}{$\underset{\text { (ft) }}{\text { Thickness }}$} & \multirow[b]{3}{*}{$\begin{array}{c}\text { Grade } \\
\text { (percent } \\
\left.\mathrm{P}_{2} \mathrm{O}_{5}\right)\end{array}$} & \multirow{2}{*}{\multicolumn{3}{|c|}{ Tonnage }} \\
\hline & & & & & & & & & & \\
\hline & & & $\begin{array}{l}\text { Above } \\
\text { entry } \\
\text { level }\end{array}$ & $\begin{array}{c}\text { First 100 } \\
\text { ft below } \\
\text { entry level }\end{array}$ & $\begin{array}{l}\text { Total } \\
\text { block }\end{array}$ & & & $\begin{array}{l}\text { Above } \\
\text { entry } \\
\text { level }\end{array}$ & $\begin{array}{l}\text { First 100 } \\
\text { ft below } \\
\text { entry level }\end{array}$ & $\begin{array}{l}\text { Total } \\
\text { block }\end{array}$ \\
\hline $\begin{array}{l}\text { Anaconda } \\
\text { Philipsburg } \\
\text { Maxville_. } \\
\text { Garrison } \\
\text { Elliston }\end{array}$ & $\begin{array}{l}6.5 \\
6.5 \\
5.0 \\
4.3 \\
\mathbf{3 . 7}\end{array}$ & $\begin{array}{l}28.0 \\
26.0 \\
27.6 \\
30.6 \\
29.5\end{array}$ & $\begin{array}{l}25.0 \\
30.0 \\
73.0 \\
21.5 \\
18.0\end{array}$ & $\begin{array}{r}2.6 \\
6.5 \\
13.0 \\
3.6 \\
3.4\end{array}$ & $\begin{array}{r}90 \\
150 \\
1,060 \\
400 \\
208\end{array}$ & $\begin{array}{l}7.5 \\
6.5 \\
8.0 \\
4.3 \\
3.8\end{array}$ & $\begin{array}{l}25.0 \\
26.0 \\
24.7 \\
30.6 \\
29.4\end{array}$ & $\begin{array}{r}26.0 \\
30.0 \\
112.5 \\
21.5 \\
19.0\end{array}$ & $\begin{array}{r}2.6 \\
6.5 \\
19.5 \\
3.6 \\
3.7\end{array}$ & $\begin{array}{r}100 \\
150 \\
1,795 \\
400\end{array}$ \\
\hline Totals and averages................. & 4.8 & 28.5 & 167.5 & 29.1 & 1,908 & 6.5 & 26.8 & 209.0 & 35.9 & 2,660 \\
\hline
\end{tabular}


batholith. Within those areas for which estimates were made, more than $41 / 2$ billion tons of $\mathrm{P}_{2} \mathrm{O}_{5}$ are estimated to be present. All this phosphate occurs in the Retort Phosphatic Shale Member of the Phosphoria Formation.

Approximately 10 percent of the phosphate rock of each grade occurs above entry level or within the first 100 feet below entry level so is readily accessible to mining. More than half of the acid-grade rock is in the Garrison district, but more than two-thirds of the furnace-grade and more than three-fourths of the lowgrade rock is in the Flint Creek Range districts.

\section{REFERENCES CITED}

Alexander, R. G., 1955, Geology of the Whitehall area, Montana : Yellowstone-Bighorn Research Proj. Contr. 195, 111 p.

Altschuler, Z. S., Clarke, R. S., Jr., and Young, E. J., 1958, Geochemistry of uranium in apatite and phosphorite: U.S. Geol. Survey Prof. Paper 314-D, p. 45-90.

Armstrong, R. J., and McKay, J. J., 1949, Mining operations of the Montana Phosphate Products Company : Am. Inst. Mining Metall. Engineers Trans., v. 184, p. 287-291.

Barnes, J. V., 1954, Structural analysis of the northern end of the Tobacco Root Mountains, Madison County, Montana [abs.] : Dissert. Abs., v. 14, no. 8, p. 1198.

Bell, L. V., and Moore, H. D., Jr., 1965, Quadrant Formation and Permian strata in the Philipsburg (Maxville) and Garrison districts, in Billings Geol. Soc., Geology of the Flint Creek Range, Montana, 16th annual Field Conference, August 1965; Billings, Mont., p. 67-72.

Billingsley, P. R., and Locke, A., 1941, Structure of ore deposits in the continental framework: Am. Inst. Mining Metall. Engineers Trans., v. 144, p. 9-59.

Calkins, F. C., and Emmons, W. H., 1915, Description of the Philipsburg quadrangle [Montana]: U.S. Geol. Survey Geol. Atlas, Folio 196, 25 p.

Canadian Mining Journal, 1954, The story of the Consolidated Mining and Smelting Company of Canada Limited: Canadian Mining Jour., v. 75, no. 5, p. 131-393.

Clarke, F. W., 1924. The data of geochemistry (fifth edition) : U.S. Geol. Survey Bull. 770, 841 p.

Condit, D. D., Finch, E. H., and Pardee, J. T., 1928, Phosphate rock in the Three Forks-Yellowstone Park region, Montana : U.S. Geol. Survey Bull. 795-G, p. 147-209.

Cressman, E. R., 1955, Physical stratigraphy of the Phosphoria formation in part of southwestern Montana: U.S. Geol. Survey Bull. 1027-A, p. 1-31.

Cressman, E. R., and Swanson, R. W., 1964, Stratigraphy and petrology of the Permian rocks of southwestern Montana: U.S. Geol. Survey Prof. Paper 313-C, p. 275-569.

Dobbin, C. E., and Erdmann, C. E., 1955, Structure contour map of the Montana plains: U.S. Geol. Survey Oil and Gas Inv. Map OM-178B.

Emmons, W. H., and Calkins, F. C., 1913, Geology and ore deposits of the Philipsburg quadrangle, Montana: U.S. Geol. Survey Prof. Paper 78, 271 p.

Fowler, W. E., 1955, Geology of the Trusty Lake-Quartz Hill Gulch area, Beaverhead County, Montana: Bloomington, Ind., Indiana Univ., unpub. Ph.D. thesis.
Freeman, V. L., Ruppel, E. T., and Klepper, M. R., 1958, Geology of part of the Townsend Valley, Broadwater and Jefferson Counties, Montana: U.S. Geol. Survey Bull. 1042-N, p. 481-556.

Gale, H. S., 1911, Rock phosphate near Melrose, Montana : U.S. Geol. Survey Bull. 470-H, p. 440-451.

Goddard, E. N., and others, 1948, Rock-color chart: Washington, D.C., Natl. Research Council (repub. by Geol. Soc. America, 1951), $6 \mathrm{p}$.

Gulbrandsen, R. A., 1966, Chemical composition of phosphoritis of the Phosphoria Formation: Geochim. et Cosmochim. Acta, v. 30, no. 8, p. 769-778.

Gwinn, V. E., 1960, Cretaceous Colorado Group west of the Boulder batholith in Montana [abs.]: Geol. Soc. America Bull. v. 71, no. 12, pt. 2, p. 1877.

1961, Geology of the Drummond area, central-western Montana : Montana Bur. Mines and Geology, Spec. Pub. 21 (Geol. Map 4).

- 1965, Cretaceous rocks of the Clark Fork Valley, central western Montana, in Billings Geol. Soc. Geology of the Flint Creek Range, Montana, 16th Annual Field Conference, August 1965 : Billings, Mont., p. 34-57.

Gwinn, V. E., and Mutch, T. A., 1965, Intertongued Upper Cretaceous volcanic and nonvolcanic rocks, central-western Montana: Geol. Soc. America Bull., v. 76, no. 10, p. 11251144.

Haynes, W. P., 1916, The Lombard overthrust and related geological features: Jour. Geology, v. 24, p. 269-290.

Jaffe, H. W., Gottfried, David, Waring, C. L., and Worthing, H. W., 1959, Lead-alpha age determinations of accessory minerals of igneous rocks (1953-1957) : U.S. Geol. Survey Bull. 1097-B, p. 65-148.

Klemme, H. D., 1949, The geology of Sixteenmile Creek area, Montana: Princeton, N. J., Princeton Univ. Doctoral Dissert. Ser. no. 10,941, $206 \mathrm{p}$.

Klepper, M. R., Honkala, F. S., Payne, O. A., and Ruppel, E. T., 1953, Stratigraphic sections of the Phosphoria Formation in Montana, 1948: U.S. Geol. Survey Circ. 260, 39 p.

Klepper, M. R., Weeks, R. A., and Ruppel, E. T., 1957, Geology of the southern Elkhorn Mountains, Jefferson and Broadwater Counties, Montana: U.S. Geol. Survey Prof. Paper 292, 82 p.

Knopf, Adolph, 1913, Ore deposits of the Helena mining region, Montana: U.S. Geol. Survey Bull. 527, 143 p.

MeGill, G. E., 1959, Geologic map of the northwest flank of the Flint Creek Range, western Montana : Montana Bur. Mines and Geology, Spec. Pub. 18 (Geol. Map 3).

McKelvey, V. E., 1949, Geological studies of the western phosphate field: Mining Eng., v. 1, no. 8, p. 270-279; also pub. as Am. Inst. Mining Metall, Engineers Trans., v. 184, p. 270279.

1956, Uranium in phosphate rock, in Page, L. R., and others, compilers, Contributions to the geology of uranium and thorium ***: U.S. Geol. Survey Prof. Paper 300, p. $477-481$.

McKelvey, V. E., Davidson, D. F., O'Malley, F. W., and Smith, L. E., 1953, Stratigraphic sections of the Phosphoria formation in Idaho, 1947-48, part 1: U.S. Geol. Survey Circ. $208,49 \mathrm{p}$. 
McKelvey, V. E., Williams, J. S., Sheldon, R. P., Cressman, E. R., Cheney, T. M., and Swanson, R. W., 1959, The Phosphoria, Park City, and Shedhorn formations in the western phosphate field: U.S. Geol. Survey Prof. Paper 313-A, p. 1-47.

McLaughlin, K. P., and Johnson, D. M., 1955, Upper Cretaceous and Paleocene strata in Montana west of the Continental Divide, in Billings Geol. Soc., Guidebook, 6th Annual Field Conference, Sept. 1955: p. 120-123.

Mahorney, J. R., 1956, Geology of the Garrity Hill area, Deer Lodge County, Montana : Bloomington, Ind., Indiana Univ., Master's thesis.

Maxwell, J. C., 1965, Geology of southwest Drummond area, in Billings Geol. Soc., Geology of the Flint Creek Range, Montana, Guidebook, 16th Annual Field Conference, August 1965 : map in pocket.

Mertie, J. B., Jr., Fischer, R. P., and Hobbs, S. W., 1951, Geology of the Canyon Ferry quadrangle, Montana: U.S. Geol. Survey Bull. 972, $97 \mathrm{p}$.

Mining World, 1955, Montana Phosphate starts open pit to mine thin ore bed on $24^{\circ}$ slope: Mining World, v. 17, no. 12, p. 44-46.

Montgomery, J. K., 1958, Geology of the Nimrod area, Granite County, Montana: Missoula, Mont., Montana State Univ., M.S. thesis.

Moore, G. T., 1956, Geology of the Mount Fleecer area, Montana: Bloomington, Ind., Indiana Univ., Ph.D. thesis.

Mutch, T. A., 1961, Geologic map of the northeast flank of the Flint Creek Range, western Montana : Montana Bur. Mines and Geology Spec. Pub. 22 (Geol. Map 5).

Mutch, T. A., and Gwinn, V. E., 1960, Westward overturning and thrusting in the Flint Creek Range, Montana [abs.] : Geol. Soc. America Bull., v. 71, no. 12, pt. 2, p. 1934.

Mutch, T. A., and McGill, G. E., 1962, Deformation in host rocks adjacent to an epizonal pluton (the Royal Stock, Montana) : Geol. Soc. America Bull., v. 73, no. 12, p. 1541-1543.

Nickelson, H. B., and Pott, R. L., 1948, Geology of the Lost Creek-Modesty Creek area, Deer Lodge County, Montana : Butte, Mont., Montana School Mines, senior thesis.

Pardee. J. T., 1913, Some further discoveries of rock phosphate in Montana : U.S. Geol. Survey Bull. 530-H, p. 285-291.

1917, The Garrison and Philipsburg phosphate fields, Montana : U.S. Geol. Survey Bull. 640-K, p. 195-228.

1918a, Ore deposits of the northwestern part of the Garnet Range, Montana : U.S. Geol. Survey Bull. 660-F, p. 159-239. 1918b, The Dunkleberg mining district, Granite County, Montana : U.S. Geol. Survey Bull. 660-G, p. 241-247.

1921, Phosphate rock near Maxville, Granite County, Montana : U.S. Geol. Survey Bull. 715-J, p. 141-145.

1936, Phosphate rock near Maxville, Philipsburg, and Avon, Montana : U.S. Geol. Survey Bull. 847-D, p. 175-188.

1950, Late Cenozoic block faulting in western Montana: Geol. Soc. America Bull., v. 61, no. 4, p. 359-406.

Peale, A. C., 1896, Description of the Three Forks quadrangle [Montana]: U.S. Geol. Survey Geol. Atlas, Folio 24, 7 p.

Popoff, C. C., and Service, A. L., 1965, An evaluation of the western phosphate industry and its resources (in five parts)-[Pt.] 2, Montana : U.S. Bur. Mines Rept. Inv. 6611, $146 \mathrm{p}$.

Poulter, G. J., 1956, Geologic map and sections of Georgetown thrust area, Granite and Deer Lodge Counties, Montana: Montana Bur. Mines and Geology Geol. Inv. Map 1, 2 sheets, scale 1 in. to $4,000 \mathrm{ft}$., with text.
Robinson, G. D., 1959, The Disturbed Belt in the Sixteenmile area, Montana, in Billings Geol. Soc., [Guidebook] 10th Anniversary [Annual] Field Conference, SawtoothDisturbed Belt area, August 13-15, 1959 : p. 34-40.

1963, Geology of the Three Forks quadrangle, Montana : U.S. Geol Survey Prof. Paper 370, 143 p.

Ross, C. P., Andrews, D. A., and Witkind, I. J., compilers, 1955, Geologic map of Montana: Washington, D.C., U.S. Geol. Survey, 2 sheets, scale $1: 500,000$.

Sheldon, R. P., 1959, Geochemistry of uranium in phosphorites and black shales of the Phosphoria formation: U.S. Geol. Survey Bull. 1084-D, p. 83-115.

Skipp, Betty, and Peterson, A. D., 1965, Geologic map of the Maudlow quadrangle, southwestern Montana: U.S. Geol. Survey Misc. Geol. Inv. Map I-452.

Sloss, L. L., and Hamblin, R. H., 1942, Stratigraphy and insoluble residues of Madison group (Mississippian) of Montana: Am. Assoc. Petroleum Geologists Bull., v. 26, no. 3, p. $305-335$.

Smedes, H. W., 1960, Early Tertiary volcanic geology of an area north and west of Butte, Montana : U.S. Geol. Survey Prof. Paper 400-B, p. B23-B24.

1962, Preliminary geologic map of the northern Elkhorn Mountains, Jefferson and Broadwater Counties, Montana: U.S. Geol. Survey Mineral Inv. Field Studies map MF-243.

-1966, Geology and igneous petrology of the northern Elkhorn Mountains, Jefferson and Broadwater Counties, Montana : U.S. Geol. Survey Prof. Paper 510, 116 p.

Stone, Jerome, 1952. The geology of the Elliston phosphate district, Powell County, Montana: Missoula, Mont., Montana State Univ., Master's thesis.

Stone, R. W., 1911, Geologic relation of ore deposits in the Elkhorn Mountains, Montana: U.S. Geol. Survey Bull. 470-B, p. $75-98$.

Stone, R. W., and Bonine, C. A., 1914, The Elliston phosphate field, Montana: U.S. Geol. Survey Bull. 580-N, p. 373-383.

Swanson, R. W., 1970, Mineral resources in Permian rocks of southwest Montana: U.S. Geol. Survey Prof. Paper 313-E, p. 661-777.

Swanson, R. W., Carswell, L. D., Sheldon, R. P., and Cheney, T. M., 1956, Stratigraphic sections of the Phosphoria Formation, 1953 : U.S. Geol. Survey Cire. 375, 30 p.

Swanson, R. W., Cressman, E. R., Jones, R. S., and Replogle, B. K., 1953, Stratigraphic sections of the Phosphoria Formation in Montana, 1949-50, part 2: U.S. Geol. Survey Circ. $303,21 \mathrm{p}$.

Swanson, R. W., McKelvey, V. E., and Sheldon, R. P., 1953, Progress report on investigations of western phosphate deposits : U.S. Geol. Survey Circ. 297, 16 p.

U.S. Department of Agriculture, 1941, Climate and man, Yearbook of Agriculture, 1941: Washington, D.C., U.S. Gort. Printing Off., $1248 \mathrm{p}$.

Wallace, R. E., Griggs, A. B., Campbell, A. B., and Hobbs, S. W., 1960, Tectonic setting of the Coeur d'Alene district, Idaho: U.S. Geol. Survey Prof. Paper 400-B, p. B25-B27.

Wanek, A. A., and Barclay, C. S. V., 1966, Geology of the northwest quarter of the Anaconda quadrangle, Deer Lodge County, Montana: U.S. Geol. Survey Bull. 1222-B, 28 p.

Weed, W. H., 1901, Geology and ore deposits of the Elkhorn mining district, Jefferson County, Montana : U.S. Geol. Survey Ann. Rept. 22, pt. 2d, p. 399-550. 



\section{Geology of Permian Rocks in the Western Phosphate Field}

GEOLOGICAL SURVEY PROFESIONAL PAPER 313

This volume was published

as separate chapters $A-F$

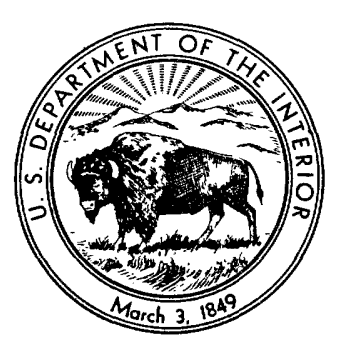




\section{UNITED STATES DEPARTMENT OF THE INTERIOR}

ROGERS C. B. MORTON, Secretary

\section{GEOLOGICAL SURVEY}

\section{E. McKelvey, Director}




\section{CONTENTS}

(A) The Phosphoria, Park City, and Shedhorn Formations in the western phosphate field, by V. E. McKelvey and others.........

(B) Physical stratigraphy and mineral resources of Permian rocks in western Wyoming, by Richard P. Sheldon.....

(C) Stratigraphy and petrology of the Permian rocks of southwestern Montana, by Earle R. Cressman and Roger W. Swanson .

(D) Biostratigraphy of the Phosphoria, Park City, and Shedhorn Formations, by Ellis L. Yochelson........ 571

(E) Mineral resources in Permian rocks of southwest Montana, by Roger W. Swanson.

(F) Geology and phosphate deposits of the Permian rocks in central western Mon-

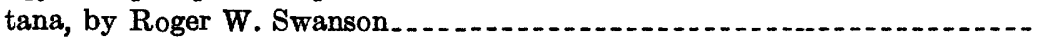

